\title{
MINERALOGIA QUIIMICA DOS ANFIBOLITOS DA REGIÃO DE MORRETES-ANTONINA, PARANÁ
}
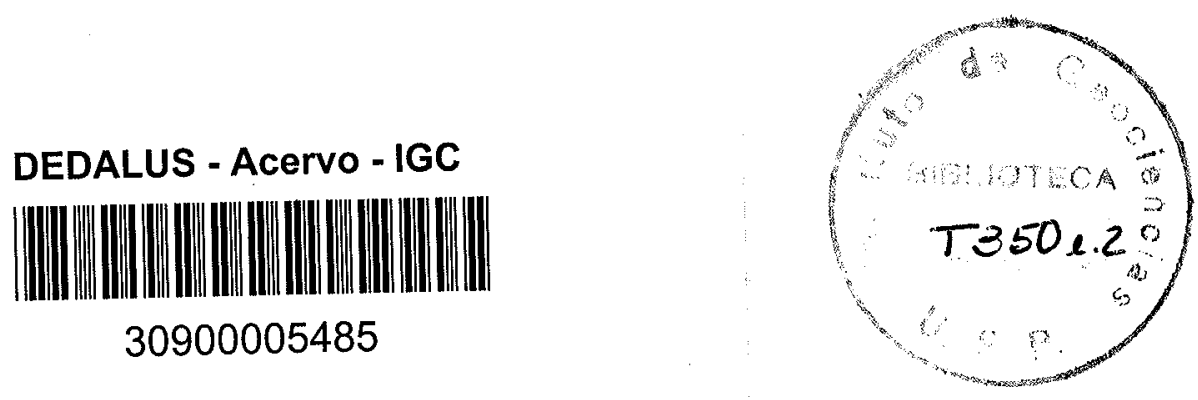

Dissertação de Mestrado apresentada ao Instituto de Geociências da Universidade de São Paulo.

Orientador :

Prof. Dr. Celso de Barros Gomes 


\section{INDICE GERAL}

INTRODUÇAOO

METODOL.OGIA

Condições de Operação 4

Feldspatos

Anfibölios

opacos

GEOLOGIA LOCAL

Migmatitos

Migmatitos homogêneos 7

Migmatitos heterogêneos

Quartzitos e quartzo-muscovita xistos

$\mathrm{X}$ istos magnesianos

11

Gonditos

Magnetita quartzitos

Granitos

Rochas intrusivas

ANFIBOLITOS

Petrografia

Andesina-labradorita anfibolitos

oligocläsio-andesina anfibolitos

Albita anfibolitos 
Mineralogia Química

Feldspatos

Discussão dos resultados

Feldspatos potássicos 34

Anfibölios 38

Discussão dos resultados 39

Zoneamento

51

Minerais opacos

Discussão dos resultados

A QUIMICA MINERAL E O GRADIENTE METAMORFICO

Feldspatos

59

Anfibölios

61

Aluminio

63

Alealis

66

Titânio

68

Opacos

70

METAMORFISMO

EVOLUÇAO DOS ANFIBOLITOS

SUMARIO E CONCLUSOES

AGRADECIMENTOS

BIBLIOGRAFIA 


\section{INDICE DAS ILUSTRAÇOES}

\section{FIGURAS}

Figura 1 - Mapa geológico da ärea de Morretes-Antonina

Figura 2 - Diagramas ternärios Ab-An-or para os plagio clásios das diversas amostras de andesina- labradorita anfibolitos.

Figura 3 - Diagramas ternārios Ab-An-Or para os plagio clásios das diversas amostras de oligoclásio-andesina anfibolitos.

Figura 4 - Diagramas ternārios Ab-An-Or para os plagio clásios das diversas amostras de albita anfibolitos.

Figura 5 - Gráfico integrando os dados constantes da Figura 2 .

Figura 6 - Gräfico integrando os dados constantes das Figuras 3 e 4 .

Figura 7 - Histograma de composição para os plagioclásios dos andesina-labradorita anfibolitos.

Figura 8 - Histograma de composição para os plagioclásios dos oligoclásio-andesina anfibolitos.

Figura 9 - Histograma de composição para os plagiociásios dos albita anfibolitos.

Figura 10 - Histograma de composição integrando os dados referentes aos andesina-1abradorita,oli goclásio-andesina e albita anfibolitos.

Figura 11 - Diagramas ternários $A b-A n-0 r$ para os feldspatos potássicos de diversas amostras de an fibolitos.

Figura 12 - Gráfico reunindo os valores de $\mathrm{Na}+\mathrm{K}$ e $\mathrm{Al}^{1 \mathrm{~V}}$ para os anfibólios investigados.

Figura 13 - Diagrama de nomenclatura, proposto por LEA$\mathrm{KE}$ (1968), reunindo valores de Si,Ca+Na+K,Ti e nümero de Niggli mg. 
Figura 14 - Diagrama de nomenclatura, proposto por LEA$\mathrm{KE}$ (1968), reunindo valores de $\mathrm{Si}, \mathrm{Ca}+\mathrm{Na}+\mathrm{K}, \mathrm{Ti}$ e nümero de Niggli mg.

Figura 15 - Gráfico reunindo os valores de $A 1^{1 V}$ e $A 1^{\text {vi }}$ para os anfibólios de Morretes-Antonina.

Figura 16 - Gráfico reunindo os valores de $\mathrm{Ca}$ e (Na+K)pa ra os anfibólios de Morretes-Antonina.

Figura 17 - Gráfico reunindo os valores de Ti e Si para os anfibólios de Morretes-Antonina.

\section{TABELAS}

Tabela 1 - Análises modais de anfibolitos da região de Morretes-Antonina.

Tabela $\mid 1$ - Composição química de plagioclāsios,expres sa em termos dos componentes $A b$, An e or, dos oligocläsios-andesina anfibolitos.

Tabela III - Composição química de plagioclásios,expres sa em termos dos componentes $A b$, An e $0 r$, dos albita anfibolitos.

Tabela IV - Composição química mëdia das diferentes fa ses de plagioclásios de anfibolitos da região de Morretes-Antonina.

Tabela $\quad V$ - Anälises quimicas parciais de feldspatos potässicos, expressas em função dos componentes moleculares Albita, Anortita e orto clàsio.

Tabela VI - Anālise modal do anfibolito E-23.

Tabela VIl - Composição química parcial de anfibölios dos andesina-labradorita anfibolitos da re gião de Morretes-Antonina.

Tabela VIII - Composição química parcial de anfibölios dos oligocläsio-andesina anfibolitos da re gião de Morretes-Antonina. 
Tabela $\quad$ IX - Förmula estrutural, expressa na base de 23 àtomos de oxigênio, dos anfibólios dos oll gocläsio-andesina anfibolitos, e nümero de Niggli mg.

Tabela $\quad x$ - Composição química parcial de anfibölios dos albita anfibolitos da regiäo de Morretes-Antonina.

Tabela $\quad x 1$ - Förmula estrutural, expressa na base de 23 àtomos de oxigênio dos anfibölios dos albi ta anfibolitos, e nümero de Niggli mg.

Tabela XII - Composição química mèdia das fases coexistentes de anfibólios nos diferentes grupos de anfibolitos.

Tabela Xlll-Composição química parcial de anfibölios zonados da região de Morretes-Antonina.

Tabela XIV - Composição química parcial de ilmenita do andesina-labradorita anfibolitos, A-184.

Tabela XV - Composição química parcial de ilmenita e magnetita dos oligoclāsio-andesina anfibolitos da região de Morretes-Antonina.

Tabela XVI - Composição química parcial de ilmenita e magnetita dos albita anfibolitos da região de Morretes-Antonina.

Tabela XVII - Composição química mëdia das fases coexistentes de opacos nos diferentes grupos de anfibolitos de Morretes-Antonina.

Tabela XVIII - Valores modais médios para os grupos de an fibolitos da região de Morretes-Antonina. 


\section{INTRODUÇAOO}

A região limitada pelas folhas geolögicas de Morretes e Antonina, Estado do Paranā, tem sido alvo de atenção desde o início do século, em virtude, sobretudo, da ocorrência de minërio de ferro e rochas manganiferas associadas. Muitos autores se ocuparam do estudo dessa região, visando mais o aspecto liga do ao minērio de ferro propriamente dito, quer enfocando a sua parte econômica, quer o seu aspecto genético. Dentre os estudos realizados nessa regiäo, destacam-se os de HUSSAK (1904; citação em LEONARDOS, 1938), OLIVEIRA (1927), ROXO (1937), LEONARDOS (1938) e LEINZ (1938). A geomorfologia da região, representada pela Serra do Mar, atraiu da mesma forma a atenção de vários autores, entre eles, DOMINGUES (1945), RUELLAN (1945), AB' SABER e BIGARELLA (1961). Por outro lado, MAACK $(1947,1953)$ realizou trabalhos de caräter mais geral, mas que tambēm se referem às feições ocorrentes na ärea.

o primeiro levantamento geolögico com detalhes da região foi efetuado por CORDANI e GIRARDI (1967), abrangendo apenas o municipio de Morretes, dele resultando a Folha Geologica de Morretes, na escala 1:75.000. Na oportunidade, esses autores concluiram que a àrea é constituída predominantemente por rochas metamörficas e ígneas prë-cambrianas, que se acham cortadas por diques de diabāsio de idade mesozóica. Dentre as metamörficas, migmatitos heterogêneos (epibolitos) são as mais comuns, alternando-se localmente com migmatitos homogêneos. Nessas rochas, encontram-se intercalados concordantemente quartzitos, quartzo-muscovita xistos, xistos magnesianos, quartzitos com magnetita, anfibolitos e rochas manganiferas. Essas variedades petrogräficas, à exceção daquelas aflorando em uma faixa situada na porção leste da ärea, que, devido ao metamorfismo regressivo, são formadas por uma assemblëia mineralögica compatível com a fäcies dos xistos verdes, foram enquadradas por aqueles autores dentro da fäcies almandina anfibolito. 
A diversidade petrogräfica, as evidências de retrometamorfismo e de zonas com grau metamörico distintos levou GIRARDI (1969, 1971) e GIRARDI e SANTINI (1973) a efetuar um estudo petrológico minucioso das rochas da região mapeada, que se estendeu tambëm ao município vizinho de Antonina. Assim procedendo,es se autor pode se ocupar igualmente das rochas anfibolíticas, de considerāvel importāncia dentro do quadro metamörfico regional em virtude de sua grande susceptibilidade às variações do gradiente. Com base nas mudanças químicas, mineralógicas e texturais ocorridas nessas rochas, esse autor conseguiu delimitar na região duas zonas metamörficas perfeitamente distintas:zona l,compreendendo rochas situadas em ärea afetada profundamente pelo me tamorfismo regressivo, e Zona 11 , compreendendo litologia aflorando em ärea onde a ação do evento foi incipiente ou mesmo inexistente. Com base em algumas evidencias quimicas, esse autor te ceu considerações quanto à origem dos anfibolitos, concluindo por admitir para os mesmos uma formação a partir de antigas rochas magmäticas bảsicas.

Face às peculiaridades mineralógicas e químicas apresen tadas por esses anfibolitos, julgou-se altamente conveniente a execução de um programa de pesquisa com vista à caracterização química de seus principais minerais. Esses dados iriam possibili tar não apenas o confronto com os öpticos existentes, mas também - exame minucioso das mudanças químicas processadas nesses minerais em resposta às variações do gradiente metamörfico. Essas transformações químicas, traduzidas nas proporções variäveis de certos elementos sabidamente sensíveis às oscilações de pressão e temperatura,permitiriam, ainda, estabelecer as intensidades relativas com que os fenómenos de metamorfismo atuaram sobre os diferentes grupos de rochas.

Cumpre tambëm acrescentar que a obtenção de dados químicos referentes a anfibölios de rochas anfiboliticas se revesti ria de grande importância, visto que a literatura especializada não conta com maiores informações a respeito do quimismo desses minerais. 
METODOLOGIA

o estudo óptico dos minerais foi feito com o auxílio de um microscōpio petrogräfico Ortholux-Pol, de fabricação leitz. As anälises modais foram levadas a efeito por meio de um contador de pontos, usando-se a tëcnica descrita em CHAYES (1949).

Para o trabalho analítico com a microssonda eletrónica, foram utilizadas secções delgadas polidas, empregando-se "araldi te" como elemento de fixação do material à lâmina. As secções fó ram cobertas com carbono, recorrendo-se a um metalizador de fabricação JEOL, modelo JEE 4E. Este ültimo trabalho teve lugar no laboratörio de microssonda eletrônica do Instituto de pesquisas Tecnolögicas.

o programa analítico foi efetuado pelo autor no labora törio de microssonda do Instituto de Geociências, empregando-se um instrumento de fabricação "Applied Research Laboratories",modelo EMX-SM, equipado com três espectrōmetros dispersivos e três pares de cristais (LiF/ADP, LiF/ADP e LiF/RAP).

Durante o trabalho analítico, realizado em 26 amostras, atenção especial foi dispensada ao fator de correção flutuação, efetuando-se leituras periódicas dos padrões utilizados para os três elementos analisados. Nos casos em que a variação da contagem no mesmo ponto foi superior a $3 \%$, a correção foi aplicada. A radiação de fundo foi determinada atravēs do método de leituras fora do ponto de sintonização (valores acima e abaixo do pico)e, no caso particular dos feldspatos, do emprego de padrões com nümero atômico mëdio similiar ao da fase desconhecida, e não portador do elemento em fase de anälise. A correção do fator tempo morto foi eliminada, mantendo-se as contagens nos contadores abaixo do limite $5000 /$ segundo.

os dados analiticos foram ainda corrigidos para os demais fatores (absorção, número atômico e fluorescência secundäria), contando-se com o auxilio do método de BENCE e ALBEE 
(1968). A exceção das ilmenitas, a precisão dos dados obtidos ë estimada em torno de $3 \%$ para os elementos maiores e cerca de $5 \%$ para os menores.

As förmulas químicas constantes das Tabelas VII, IX e $X I$ foram calculadas, de conformidade com BINNS (1965), na base de 23 ätomos de oxigênio, uma vez que as anälises desses anfibolios são parciais (valores de $\mathrm{H}_{2} \mathrm{O}$ não foram determinados).

Para quase todas as amostras analisadas, os valores lís tados nas tabelas correspondem à média aritmética de pelo menos 60 determinações em grânulos diferentes. Cuidados especiais foram tomados quanto à homogeneidade dos cristais, com as medidas tendo lugar nas suas bordas e porção central.

\section{Condições de Operação}

Feldspatos - Foram analisados apenas os elementos $\mathrm{Na}$, Ca e K uma vez que eles são suficientes para a caracterização desses minerais. A sua composição acha-se expressa em termos dos componentes moleculares albita, anortita e ortocläsio. Como padrões, foram utilizados cristais naturais de plagioclásio e orto cläsio, procurando sempre que possível usar os de composição pró xima ao da fase analisada. Devido ao uso desses padrões, as correçōes nesses minerais ficaram limitadas apenas aos fatores instrumentais, flutuação e radiação de fundo, Para a transformação dos dados em percentagem dos componentes moleculares, foi utilizado um programa de computação de uso interno (SLAVE).

As condições de instrumentação foram as seguintes: potencial de aceleração $15 \mathrm{Kv}$, corrente de amostra 0,03 a $0,06 \mu \mathrm{A}$, tempo de integração nos contadores $10^{\prime \prime}$, e diâmetro do feixe eletrónico aproximadamente $20 \mu$. 0 intervalo curto de integraçóo associado ao grande diàmetro do feixe foram escolhidos para evicar - se problemas de volatização do Na e K. Os padrões utilizados fo ram: albita (Tiburon), andesina (AC-362), labradorita (Lake View) 
e ortoclàsio $(0 r \neq 1)$.

Anfibölios - A presença de padröes adequados, pelo menos para as fases de composição pröxima a hornblendas, facilitou em muito o trabalho analítico, obtendo-se, assim, resultados razoavelmente precisos. A exceção do fator flutuação, todos os demais foram rotineiramente aplicados. As condiçōes de instrumenta ção utilizadas foram as seguintes: potencial de aceleração $15 \mathrm{KV}$, corrente de amostra 0,03 a $0,05 \mu \mathrm{A}$, tempo de integração nos conta dores $20^{\prime \prime}$ e diámetro do feixe eletrónico aproximadamente 14. Como padrões, foram empregados apenas cristais naturais, a saber, hornblenda (Arenal) para os elementos Ti e Mn e hornblenda (Kakanui) para os demais.

Estruturas zonadas nesses minerais foram determinadas mediante o traçado hipotëtico de perfis transversais nos cristais. Esse procedimento foi controlado manualmente, uma vez que o "step scan attachment", dispositivo que permite o deslocamento automático, mantendo-se o espaçamento constante, ao longo do per fil, apresentava, na oportunidade, problemas técnicos.

Opacos - Como minerais opacos presentes nessas rochas foram identificados tão somente ilmenita e magnetita. Para a sua caracterização mineralógica foram analisados apenas os elementos Ti, Fe e Al. A anālise das magnetitas viu-se facilitada face à existência de padrão natural, o mesmo não ocorrendo no entanto com as ilmenitas. Para as magnetitas, os dados foram corrigidos apenas para os fatores flutuação e radiação de fundo. As condições de instrumentação foram os seguintes: potencial de aceleraçäo, $15 \mathrm{Kv}$, corrente de amostra 0,03 a $0,05 \mu \mathrm{A}$, tempo de integração, 20 " e diâmetro do feixe 14. Como padrão, foi utilizada a magnetita $(L 4-175)$. 
GEOLOGIA REGIONAL

Ao longo da costa Atlāntica, desenvolveu-se um sistema de dobramentos constituido, alternadamente, por faixas dobradas e maciços medianos. A sua direção geral é NE-SW, e se estende desde o sul da Bahia até o Uruguai, formando o assim chamado sistema de dobramentos Ribeira (HASUl et al., 1975).

Esse sistema inclui três faixas de rochas epimetamörficas denominadas faixas de dobramentos Apiaí, Tijucas e Uruguai oriental, além de rochas meso e catazonais pertencentes aos maci ços medianos de Joinville e Pelotas.

A faixa de dobramentos Apiaí engloba os Grupos São Roque, SP, e Açungui, $P R$, enquanto que a Tijucas é constituída pelos Grupos Brusque, SC, Porongos, RS, e Lavalleja, Uruguai. Por sua vez, a faixa de dobramentos uruguai oriental contém tão somente o Grupo Rochas.

Essas faixas de dobramentos são formadas por espessos pacotes de rochas ectiniticas, representadas por metassedimentos clásticos finos a grosseiros, clästico-químicos e químicos, que vieram a ser sede não só de abundantes corpos graniticos, como também de uma intensa atividade vulcānica bäsica,esta ocorrida no mesozóico. Esse magmatismo, reunindo intrusivas äcidas até bä sicas, parece ter sido o fator responsävel por uma sērie de transformações químicas e petrolögicas, causando fenômenos $10-$ cais de metamorfismo de contato, de diaftorese, etc.

Os anfibolitos da região de Morretes-Antonina encontram - se intercalados em rochas tidas como a base do Grupo Açungui, da faixa de dobramentos Apiaí. Consequentemente, essas rochas, juntamente com as interrelacionadas formadas no mesmo evento metamörfico regional, foram atingidas por processos geolögicos subse quentes, ocasionando importantes transformaçöes mineralögicas. 
GEOLOGIA LOCAL

A regiäo de Morretes-Antonina situa-se numa ärea constituida predominantemente de gnaisses e migmatitos nos quais se acham intercalados concordantemente anfibolitos, xistos magnesianos, quartzitos, quartzo-muscovita xistos, magnetita quartzi tos, gonditos e clorita xistos (Figura 1), a maioria dessas rochas ocorrendo em escala de afloramento.

Migmatitos

A ärea em apreço é formada, em sua maioria, por rochas sedimentares metamorfoseadas em escala regional, aparecendo mig matitos como a litologia mais comum. CORDANI e GIRARDI (1967), com base em dados mineralögicos e estruturais, enquadraram-nos na fäcies almandina anfibolito de TURNER e VERHOOGEN (1960), bem como assinalaram que as rochas migmatíticas da região leste evi denciam expressivos fenômenos de diaftorese. Esses autores, pro curando seguir as convenções das folhas geolögicas adjacentes, separaram essas variedades em migmatitos homogêneos (embrechitos) e migmatitos heterogêneos (epibolitos), em consonância com a classificação de JUNG e ROQUES (1952). Esses dois tipos litologicos principais foram separados arbitrariamente, pois encontram-se muitas vezes intimamente associados, interdigitados, ou mesmo gradando lateralmente entre si.

Migmatitos homogêneos - os migmatitos homogêneos são gnaisses leucocrāticos ou biotita gnaisses de granulação média a grossa, e aspecto granitöide, sendo que apenas esporadicamente apresentam bandamento, ainda que irregular e pouco nítido. A sua textura é geralmente granoblástica equigranular, com cristais xenoblásticos, podendo eventualmente ocorrer porfiroblas 
MAPA GEOLÓGICO DA REGIÃO DE MORRETES - ANTONINA, PR

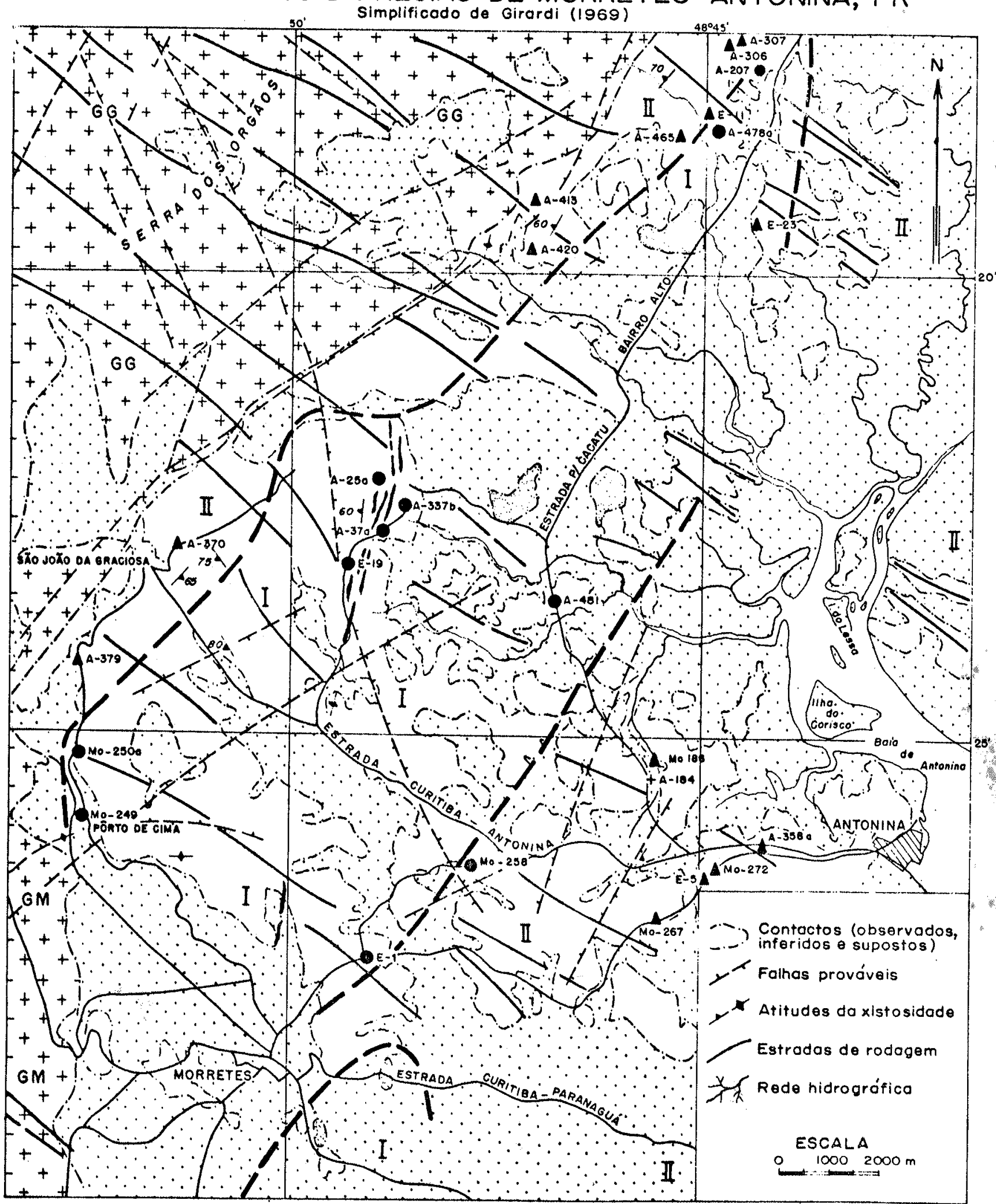

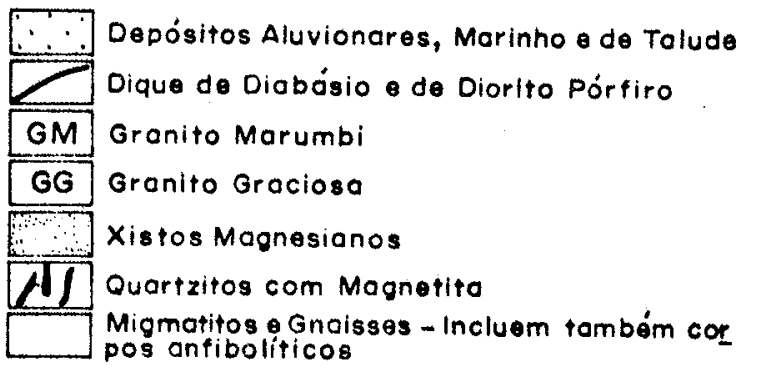

+ Andesina - Labrodorita Anfibolitos

- Oligociásio-Andesina Anfibolitos

- Albita Anfibolitos

Limite daszonas Metamórficas

I Áreaprofundamente ofetado pelo metamorfismo regrasaivo

II Áreo de metomorfismo retrógrodo incipiente ou inexistente 
tos de feldspato potässico.

Mineralogicamente, eles caracterizam as partes claras dos epibolitos. Os seus constituintes principais são quartzo, feldspato potāssico (em geral microclínio) e plagioclàsio (oligo cläsio-andesina), E frequente a ocorrência de intercrescimentos pertítico, antipertítico, ou mesmo gräfico. Biotita é o mineral ferromagnesiano mais comum, aparecendo na forma de cristais placóides, isolados ou agrupados na massa quartzo-feldspätica. Por outro lado, hornblenda acha-se raramente presente. Cloritização da biotita é uma feição comum. Como acessōrios, foram reconhecidos zircão, allanita, epídoto, titanita, sericita, fluorita e opacos.

Migmatitos heterogêneos - os migmatitos heterogêneos (epibolitos) são rochas que se caracterizam por um nítido bandamento subparalelo evidenciado pela alternância de faixas claras, contendo minerais félsicos, e escuras, estas ricas em minerais mäficos. Essas faixas apresentam geralmente espessura centimétri ca.

Tanto a disposição dos minerais placōides e alongados nas bandas escuras (xistosidade), como tambēm das faixas subpara lelas, é feita segundo direções concordantes para toda a região, dominantemente NNE. Os mergulhos são em geral muito fortes, ora para NW, ora para SE.

As bandas fëlsicas apresentam textura claramente equigranular e contêm quartzo, feldspato potássico (geralmente micro clínio) e plagioclàsio (oligocläsio-andesina) como principais constituintes. As mäficas exibem xistosidade paralela à direção da estrutura gnäissica e, mineralogicamente, são constituídas de biotita, epidoto, hornblenda, muscovita, titanita, opacos, allanita, zircão e clorita.

Petrograficamente, essas rochas são definidas em função da variação das proporções mineralógicas que ocorrem nas bandas claras e escuras. Nos tipos mais claros, onde predominam as bandas félsicas, a rocha é classificada como um biotita gnaisse, e 
a essas faixas correspondem "suites" variando de composição granitica a granodioritica.

Os tipos mais escuros, fato devido à predomināncia de bandas mäficas xistosas, são classificados como biotita-hornblen da gnaisses. Em geral, as bandas claras têm composição adamellítica a granodioritica, ou mesmo em alguns casos quartzo-diorítica; por outro lado, as bandas escuras têm biotita como mineral predominante, apesar de hornblenda ocorrer em quantidades consi deràveis.

Um ültimo tipo de rocha migmatítica,de ocorrência mais rara, consiste da alternáncia de bandas granoblästicas (composição granitico-adamellítica) com material micāceo, aparecendo mus covita como mineral predominante. Trata-se de um muscovita gnais se.

As associaçōes mineralögicas dos gnaisses acima referidos permitem englobar tais rochas na fäcie almandina anfibolito de TURNER e VERHOOGEN (1960). Por outro lado, a existência de uma extensa ärea na região leste, onde as bandas escuras são constituidas de epidoto (em grande parte englobado por albita), muscovita (sericita), biotita e, em menor proporção, de clorita, apatita, opacos e zircão, e as bandas claras de quartzo;albita e microclínio, por vezes pertítico, permite a caracterização de uma zona de mais baixo metamorfismo, enquadrada na fácies xistos verdes daqueles autores.

As rochas migmatíticas da ärea acham-se cortadas por enormes corpos graníticos e diques de diabásio e diorito, estes ültimos preenchendo fraturas, alëm de associadas a intercalações concordantes de xistos magnesianos, clorita xistos, quartzitos, magnetita quartzitos, quartzo-muscovita xistos, gonditos e anfibolitos. Estas, à exceção dos anfibolitos, objeto de estudo dos prōximos capítulos, serão brevemente descritas visando uma melhor caracterização da geologia regional, bem como a inserção dos anfibolitos no seu contexto. 
Quartzitos e quartzo-muscovita xistos

Essas rochas ocorrem na forma de inclusões lenticulares, invariavelmente concordantes com os migmatitos. A sua espessura e irregular, variando de poucos centímetros a dezenas de metros. São xistosas e apresentam coloração esbranquiçada ou avermelhada. Na região leste da àrea, evidências de cisalhamento são relativa mente comuns.

Xistos magnesianos

Ao longo de uma faixa intercalada nos migmatitos regionais, aparecem xistos magnesianos orientados segundo $N 20 \mathrm{E}$. Acham-se localizados na região atingida pelo metamorfismo retró grado, sendo possivel reconhecer-se dois tipos principais: talco xistos, exibindo xistosidade muito pronunciada, granulação fina, cor cinza, e tendo talco como constituinte predominante, e tremo Zita-talco xistos, mostrando granulação mais grossa que a dos primeiros, xistosidade nitida, cor cinza-esverdeado e uma textura variävel, ora equigranular, ora porfiroblästica, contendo no ül timo caso cristais bem desenvolvidos de tremolita.y Essa associação mineralögica permitiu CORDANI e GIRARDI (1967) enquadrälos na fäcies xistos verdes de TURNER e VERHOOGEN (1960).

Gonditos

Essas rochas metamórficas de natureza manganifera ocorrem associadas aos gnaisses e migmatitos da fácies almandina anfibolito. Caracterizam-se por sua alta densidade, aspecto maciço e coloração cinza escuro. A sua assemblēia mineralögica contém granada, com predomínio do membro espessartita, anfibólio da sé- 
rie cummingtonita-grunerita, piroxênio, quartzo em quantidade va riāveis, opacos, além de apatita e biotita como acessörios.

Magnetita quartzitos

Essa variedade petrogräfica, tão comum e de particular interesse econômico, ocorre na forma de lentes intercaladas nos migmatitos regionais. A exemplo dos xistos magnesianos, acha-se tambëm situada na zona retrometamórfica. A sua cor e densidade estão condicionadas às proporções relativas de quartzo e magneti ta. A espessura das lentes é variāvel, chegando a atingir algumas dezenas de metros. Intercalados a essas rochas aparecem clorita xistos com uma mineralogia simples, em que clorita é o mine ral predominante, e contendo quartzo em quantidades subordinadas. Magnetita, juntamente com apatita, zircão, epídoto e sericita,es tão presentes na qualidade de acessōrios.

Granitos

A região em foco acha-se recortada por dois enormes maciços graníticos, o de Marumbi e o Graciosa.

o maciço granítico Graciosa, de forma alongada, possui direção geral NE, e, a grosso modo, mostra-se concordante relati vamente às estruturas metamörficas regionais. Em quase toda a sua extensão, acha-se em contato direto com os migmatitos. As ro chas apresentam cores claras, textura hipidiomörfica granular e uma "suite" mineralögica essencial formada de quartzo, feldspato potässico e plagiocläsio. Geminação em grade é pouco freqüente no feldspato potässico, que, no entanto, pode mostrar-se geminado segundo as leis de Carlsbad e Baveno. Anälises de raios $x$ per mitiram classificar esse mineral como um ortocläsio micropertít co anōmalo. o plagioclāsio é albita, enquanto que biotita e anf 
bölio, alēm de piroxênio sōdico, podem estar presentes em proporções variāveis. Esses dois ültimos minerais ocorrem tão somen te nas variedades mais alcalinas do maciço. Anälises químicas (MAACK, 1961) permitiram enquadrar o maciço Graciosa, apesar da heterogeneidade de suas rochas, no grupo dos chamados granitos alcalinos.

- granito Marumbi difere do Graciosa pela sua maior homogeneidade mineralögica e textural. Apresenta uma coloração pre dominantemente cinza claro e, do ponto de vista mineralögico, é constituído de quartzo, feldspato potässico sem geminação em gra de e plagioclàsio $\left(A n_{2-8}\right)$. Intercrescimento pertitico é comum. 0 principal mineral mäfico é a biotita, não tendo sido reconhecidos anfibōlios ou piroxênios alcalinos. Esses minerais dispõem-se no conjunto formando uma textura equigranular milimétrica. A anālise química de uma amostra permitiu a MAACK (1961) concluir que o seu magma parental apresentava um caräter menos alcalino que o exibido pelo granito Graciosa.

Os contatos dos granitos Graciosa e Marumbi com os migmatitos regionais são nitidamente tectônicos, com a formação de grandes falhas. Por outro lado, na borda ocidental do granito Graciosa, GIRARDI (1969) menciona a ocorrēncia de anfibolitos (A-379 e A-467) exibindo evidências de metamorfismo de contato.

Rochas intrusivas

o surto de intrusivas básicas ocorrido no mesozóico em todo o sul do Brasil afetou tambëm a região de Morretes-Antonina. Segundo MARINI et al. (1967), a direção geral desses corpos no És tado do Paranā è N50-60\%, e a sua freqüência média cerca de 1,5 diques/km nas zonas de maior densidade. Na região em apreço, a frequíncia desses diques è superior a l dique/km, e as suas es pessuras variam de $20-50 \mathrm{~m}$, podendo mesmo atingir até 100 metros (CORDANI e GIRARDI, 1967).

o tipo petrogrä́fico mais comum é o diabásio, com os mi- 
nerais se arranjando segundo uma textura ofítica a subofitica.Mi neralogicamente, predominam plagiocläsio e piroxénio, ocorrendo em menor quantidade hornblenda, biotita, epídoto, opacos, quartzo, feldspato potässico e apatita. Comumente o plagioclásio acha-se geminado segundo a lei albita e, mais raramente, segundo periclí nio e Carlsbad. A sua composição è razoavelmente homogénea, com - teor da molécula de anortita variando de An 54 a An 64 . Augita é - clinopiroxēnio predominante, aparecendo subsidiariamente pigeo nita. Hornblenda é um típico produto de uralitização do piroxênio, enquanto que biotita, também um mineral de alteração,ocorre intersticialmente. Ouartzo forma cristais isolados ou ocorre intercrescido granofiricamente com o feldspato potässico.

Dois enormes diques de diorito pörfiro atravessam a região de Morretes, alcançando suas espessuras cerca de 100 metros. Essas rochas exibem uma matriz afanitica escura onde se so bressaem fenocristals milimētricos de plagioclāsio, piroxênio e minerais opacos. Ao microscópio, a matriz é holocristalina e alo triomörfica, e constituída de plagiocläsio, piroxênio, hornblenda, quartzo (intercrescido granofiricamente com feldspato potássico), biotita, apatita e opacos.

o plagiocläsio da matriz é menos cälcico $\left(A_{30-48}\right)$ que o correspondente aos fenocristais $\left(A n_{46-61}\right)$. Por sua vez, o piro xênio, tanto fenocristais como pertencentes à matriz,corresponde principalmente a uma augita, conquanto pigeonita também esteja presente. Hornblenda provém da uralitização do piroxênio. 


\section{ANF I BOL ITOS}

\section{Petrografia}

Os anfibolitos da região de Morretes-Antonina exibem invariavelmente coloração verde escuro e mostram-se constituí dos predominantemente de plagiocläsio e anfibölio. Sua textura é variàvel, passando de xistosa a granoblästica, e a granulação grada em geral de fina a mëdia.

Quando estudando essas rochas, GIRARDI $(1969,1971)$ ob teve as anälises modais que constam da Tabela l, agora acrescidas com os novos dados obtidos durante este trabalho. Na oportu nidade, baseado em dados öpticos, esse autor concluiu que as ro chas anfibolíticas da ärea são extremamente heterogêneas, sendo mesmo possível dividi-las em grupos distintos, a partir da composição do seu plagioclásio. os dados químicos dos principais minerais obtidos com a técnica da microssonda eletrōnica endossam inteiramente aquelas observações, sustentando, assim, a sub divisão que se segue.

Andesina-Zabradorita anfibolitos - Na ärea investigada, foram reconhecidos apenas dois afloramentos de andesina-labradorita anfibolitos (CORDANI e GIRARDI, 1967; GIRARDI, 1969, 1971), fato também confirmado pelo novo programa de coleta de amostras.

Esses anfibolitos apresentam granulação mēdia e textu ra granoblästica ou mesmo nematoblästica. 0 exame de suas anāli ses modais (Tabela 1) evidencia que hornblenda e plagioclásio constituem mais de $85 \%$ do volume da rocha. Subordinadamente, e tão presentes epídoto, quartzo, opacos, titanita, zircão e piro xênio.

Hornblenda, o mineral mais importante dessas rochas, é o ünico anfibölio presente, apresentando coloração dominante- 
TABELA 1

Anälises modais de anfibolitos da iegiāo de korretes - Antonina

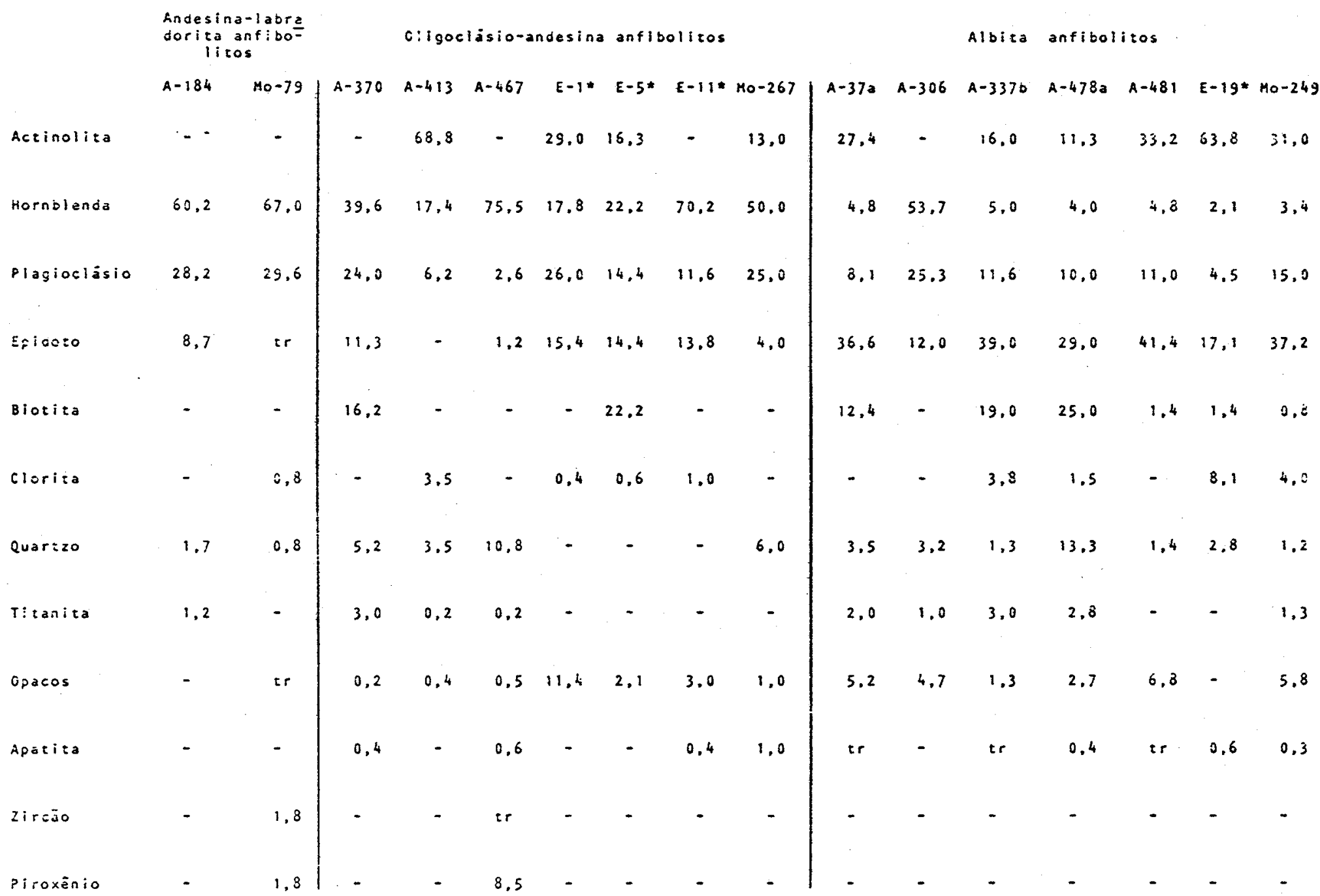


mente marrom. Em geral, não exibe grandes evidencias de alteração, sendo mesmo insignificante a quantidade de clorita formada às suas expensas. Em uma ünica amostra verificou-se a presen f̧a de piroxênio, que, a julgar pelas relaçōes texturais, parece ter-se formado contemporaneamente aos demais minerais primärios da rocha.

0 plagiocläsio apresenta-se em geral com forma granular ou tendendo a alongada, mostrando-se geminado neste ültimo caso. Comumente acha-se inalterado, com o teor de anortita, determinado por mëtodos öpticos, variando de $A_{40}$ a An 54 (GIRARDI, 1969, 1971). Epidoto é o mineral mais freqüente entre os consti tuintes menores, correspondendo na quase totalidade dos casos (exceção amostra $A-184$ ) a uma fase primäria, isto è, que não se formou às expensas do plagiocläsio ou do anfibólio.

A composição mineralógica essencial, hornblenda e plagiocläsio cálcico, aliada à presença ocasional de restos de piroxēnio, a ausência de actinolita e biotita, bem como as ocorrências restritas de epídoto, clorita e titanita em relação às demais rochas anfiboliticas regionais são indicativas, conforme GIRARDI (1969, 1971), que os andesina-labradorita anfibolitos pertecem à fäcies de mais alto grau metamórfico na região, a fäcies anfibolito de TURNER (1968).

oligocläsio-andesina anfibolitos - Enquadram-se nesse grupo as rochas anfiboliticas onde o teor de anortita dos plagioclásios acha-se situado dentro do campo de variação oligoclá sio-andesina. Aparentemente, trata-se da variedade de anfibolitos mais comum da região.

A sua associação mineralógica ē simples, essencialmente anfibōlio e plagioclásio (Tabela 1), com os minerais se arranjando de forma tal a conferir à rocha uma textura ora granoblästica, ora nematoblästica.

o plagiocläsio é menos abundante que o anfibölio e mos tra-se poucas vezes geminado. 0 seu teor em anortita, determina do opticamente, varia, segundo GIRARDI $(1969,1971)$, de An 25 a 
$\operatorname{An}_{35^{\circ}}$

Preliminarmente, pode-se dizer que os dados químicos re ferentes a esses minerais, e que foram obtidos com a microssonda eletrônica, estão em consonância com os primeiros, podendo, no en tanto, ir algumas vezes um pouco alëm daqueles limites. Contudo, uma única ressalva deve ser feita, a amostra A-306, que consta da tabela fornecida por GIRARDI (1969, 1971) como pertencente ao grupo dos oligocläsio-andesina anfibolitos. As anälises de microssonda revelaram que o seu plagiocläsio é essencialmente sódi co, com um teor em anortita abaixo de 3,5\%. Considerando, tambēm, que o anfibólio dessa amostra tem composição actinolitica, julgou-se mais conveniente enquadräla no grupo dos albita anfiboli tos.

Um fato ainda digno de registro no tocante ao plagioclä sio $\dot{e}$ o seu comportamento heterogêneo para diferentes rochas, mostrando-se praticamente inalterado em algumas amostras (exemplo $E-11)$ e quase que inteiramente transformado em epídoto em ou tras.

Comportamento anālogo ao descrito é observado com o anfibölio, pois na maioria das amostras onde a transformação do plagioclásio não se fez sentir, hornblenda é o ünico representan te do grupo, enquanto que, em outras, mostrando sinais evidentes de alteração, o mineral acha-se parcialmente transformado em actinolita ou mesmo clorita. Uma feição muito comum consiste na presença de nücleos de hornblenda marrom envolvidos por hornblen da verde, a indicar mudanças nas condições metamörficas reinantes.

Ao lado dos minerais acima, aparecem ainda biotita, de ocorrência acidental, e epídoto, este seja de natureza primäria, seja proveniente da transformação do plagioclásio.

o comportamento heterogéneo dessas rochas, como indica do pela presença ou näo de actinolita, clorita e epídoto, pela ocorrência ocasional de biotita, bem como pela grande variação na concentração de hornblenda, constitui a evidência inicial apontando no sentido da existência de atividades diaftoréticas 
na ärea. Por outro lado, as associações mineralögicas presentes nessas rochas parecem condizentes com um gradiente metamōrfico inferior àquele atingido pelos andesina-labradorita anfibolitos (GIRARDI, 1969, 1971).

Albita anfibolitos - A extensa ärea situada a leste de São João da Graciosa acha-se fortemente afetada por esforços de cisalhamento (CORDANI e GIRARDI, 1967), com reflexos diretos na litologia, que se apresenta constituida de rochas mostrando as sociações mineralögicas bem distintas das anteriores.

os constituintes minerais dos anfibolitos, que se encon tram intercalados àquelas rochas, apresentam tambēm diferenças marcantes em relação aos demais grupos da região,particularmente a composição extremamente albítica do seu plagiocläsio. Hornblen da acha-se quase que inteiramente transformada em actinolita, en quanto que epídoto e biotita estão presentes em quantidades apre ciäveis (Tabela 1). Ao lado desses minerais, aparecem, ainda, clorita, quartzo, titanita, opacos e apatita. A textura mostra- se mais xistosa, com um carāter dominantemente nematoblästico.

GIRARDI (1969, 1971) determinou opticamente o teor de anortita do plagioclásio nessas rochas, tendo encontrado valores situados entre $A_{0}$ e $A n_{5}$, que, por sinal, são inteiramente con cordantes aos obtidos por microssonda eletrônica. 0 baixo teor em anortita desses minerais evidencia a existência de processos de alteração mineralōgica levando à formação de albita. Essa mu dança, que se constitui em feição comum junto a processos retró metamörficos, foi tão marcante na ärea a ponto de originar ro chas tendo epidoto como um dos constituintes mineralógicos mais importantes. Certas amostras, como exemplificado pela E-19, con têm plagioclāsio tão alterado,que o epídoto, secundārio, acha-se completamente moldado pelos poucos cristais restantes.

Enquanto que, na região como um todo, hornblenda marrom aparece em abundância, nesta faixa especificamente ela desapare ce quase que totalmente, com os poucos cristais remanescentes, ago ra de coloração esverdeada, ocorrendo intersticialmente. Como 
jä observado por GIRARDI (1969, 1971), a maior parte desse mine ral viu-se transformado em clorita, biotita, actinolita, epído to, titanita, etc. Com isso esses minerais ganham uma maior participação como constituintes da rocha, com o anfibölio agora uma actinolita (típico produto de transformação da hornblenda), mantendo a sua condição de mineral mais abundante.

Dentro de um contexto metamōrfico geral, as pequenas quantidades de hornblenda verde residual e plagiocläsio, o evi dente aumento da concentração de actinolita, epídoto, clorita e titanita, produtos de alteração dos primeiros minerais (Tabela 1), e o baixo teor da molēcula de anortita do plagioclásio são evidências concretas da ação de processos de retrometamorfismo na ärea, e permitiram a GIRARDI (1969, 1971) enquadrar esses an fibolitos na fäcies xistos verdes de TURNER e VERHOOGEN (1960) e TURNER (1968).

Mineralogia Química

FeZdspatos - Estudos öpticos e por microssonda eletrô nica permitiram concluir que esse grupo de minerais acha-se re presentado nas rochas anfibolíticas da ärea principalmente por plagioclásios, com os feldspatos alcalinos aparecendo esporadi camente. Dessa forma, as considerações que serão feitas a se guir dizem respeito, sobretudo, aos primeiros minerais.

Esses minerais exibem häbito granular, com dimensões variāveis entre 0,1 e $3 \mathrm{~mm}$, e mostram-se comumente geminados. Quando isto ocorre eles apresentam geminações segundo as leis da albita, albita-Carlsbad e periclínio. os plagiocläsios per tencentes às rochas localizadas na já referida faixa de cisalhá mento encontram-se extremamente alterados, com enorme quantida de de epídoto incluso no interior dos cristais. Como menciona do anteriormente, o estudo öptico desses minerais efetuado por GIRARDI (1969, 1971) demonstrou que eles têm composição hetero 
gênea, a ponto de ser possível dividir os anfibolitos da região em três grupos distintos: andesina-labradorita, oligocläsio-ande sina e albita anfibolitos. O comportamento químico dos demais minerais coexistentes parece acompanhar as mudanças ocorridas na composição dos plagioclásios.

Discussão dos Resultados - A determinação por microssonda das concentrações de $\mathrm{Na}, \mathrm{Ca}$ e $\mathrm{K}$ em vinte e seis amostras foi feita tendo por objetivo principal a caracterização química dos felds patos, bem como o estudo do comportamento desses elementos.

Os dados constantes das Tabelas II a IV,correspondentes a valores mëdios para diferentes amostras, foram obtidos a par tir de 1.710 determinações da composição química de feldspatos, e acham-se expressos em termos da porcentagem em peso dos compo nentes moleculares albita, anortida e ortoclásio. A composição mëdia de cada grupo acha-se contida na Tabela IV. Em algumas amostras, notou-se a presença de plagiocläsio com alto teor em anortida coexistindo com albita. A fim de proporcionar uma visão geral dos dados foram construídos histogramas de composição, reu nindo frequência dos pontos analisados e teor de anortita (Figu ras 7 a 10 ), que serão discutidos posteriormente.

As anālises realizadas para cada amostra acham-se proje tadas individualmente em diagramas ternārios Ab-An-Or (Figuras 2 a 4), com todos os dados reunidos nas figuras 5 e 6 .

os resultados confirmam inteiramente as observações fei tas anteriormente de que, com raras exceções, esses minerais per tencem à sērie dos plagiocläsios. Tambëm não ficou caracterizá do qualquer zoneamento, assim que, por exemplo, nas amostras E-1, E-23 e A-307 (Figura 3), cujas anālises da borda dos cris tais (círculos vasios) foram separadas das do nücleo. (círculos cheios), a variação é pequena a não permitir que se interprete a feição como sendo uma estrutura zonada.

A análise da Figura 2 demonstra que o comportamento do plagioclásio nas duas amostras de andesina-labradorita anfibol 


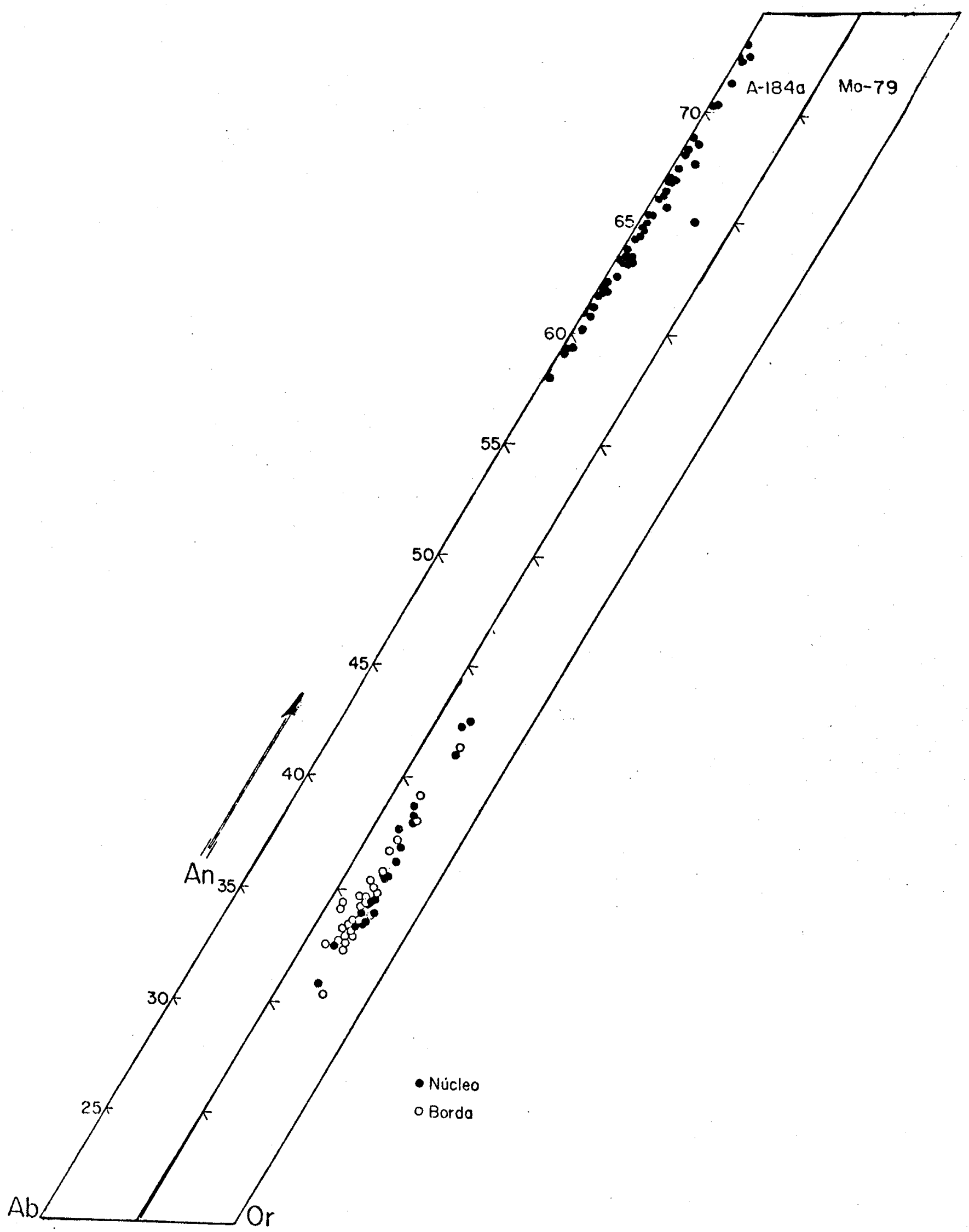

Figura 2 - Diagramas ternärios Ab-An-Or para os plagioclásios das diversas amostras de andesina-1abradorita anfibolitos. 
TABELA | I

Composição química de plagioclásios, expressa em termos dos componentes Ab, An e or, dos oligoclásio-andesina anfibolitos

$\begin{array}{rrrrrrrrrrr} & A-307 & A-358 a & A-370 & A-379 & A-379 * & A-413 & A-413 * & A-413 * & A-465 & A-465 * \\ \text { Ab } & 72,3 & 65,3 & 75,0 & 57,2 & 34,2 & 74,2 & 61,9 & 67,9 & 78,5 & 68,5 \\ \text { An } & 27,6 & 34,2 & 23,2 & 40,9 & 65,0 & 25,5 & 37,7 & 31,6 & 21,9 & 31,0 \\ \text { Or } & 0,1 & 0,5 & 1,8 & 1,9 & 0,8 & 0,3 & 0,4 & 0,5 & 0,6 & 0,5\end{array}$

$\begin{array}{rrrrrrrrr} & E-1 & E-5 & E-11 & E-11 * & E-23 & E-23 * & \text { Mo-186 } & \text { Mo-272 } \\ \text { Ab } & 52,9 & 74,7 & 77,2 & 67,9 & 73,3 & 95,9 & 75,9 & 75,8 \\ \text { An } & 45,8 & 24,7 & 22,5 & 31,9 & 25,7 & 3,6 & 22,6 & 23,5 \\ \text { Or } & 1,3 & 0,6 & 0,3 & 0,2 & 1,0 & 0,5 & 1,5 & 0,7\end{array}$

*Fases coexistentes 


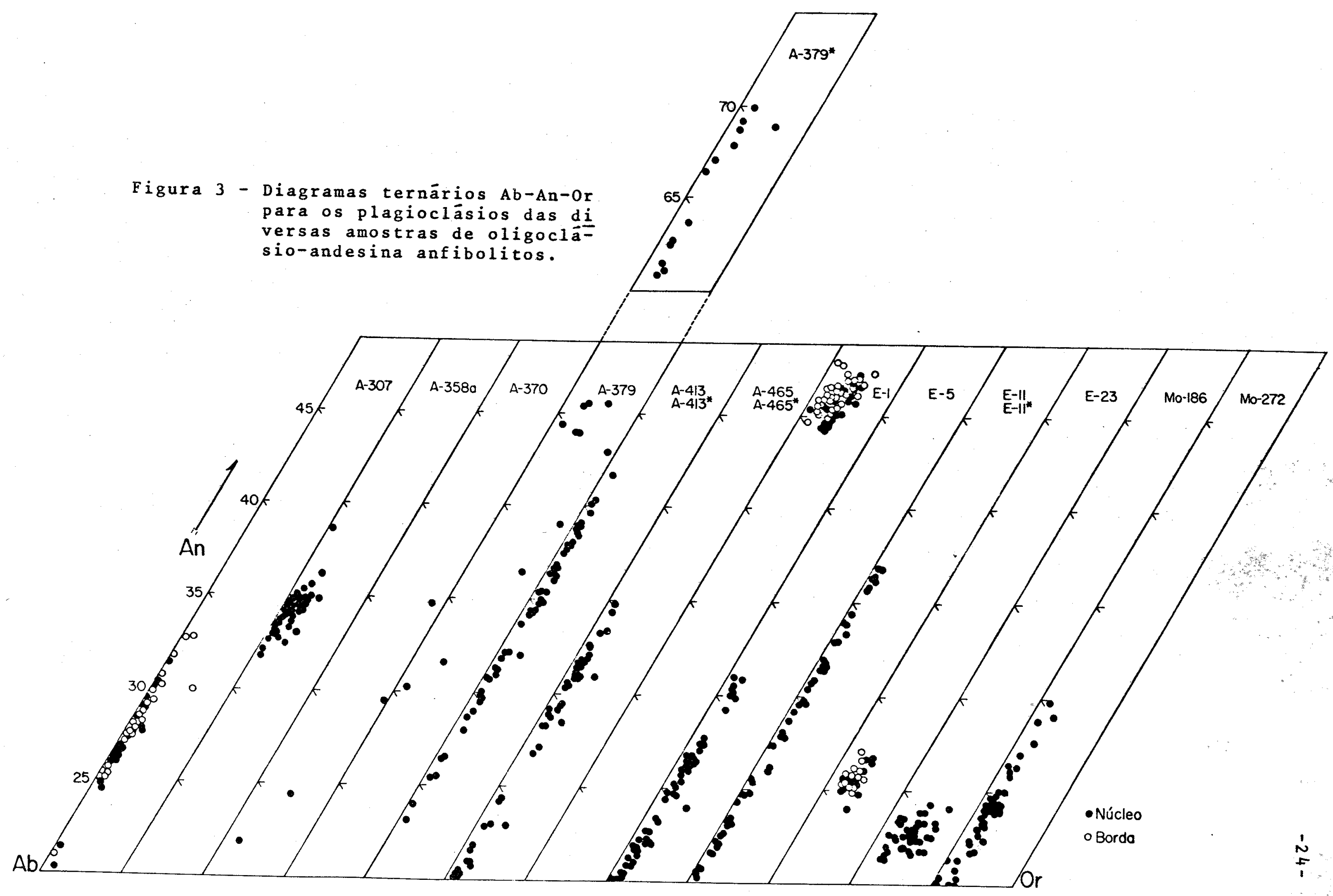




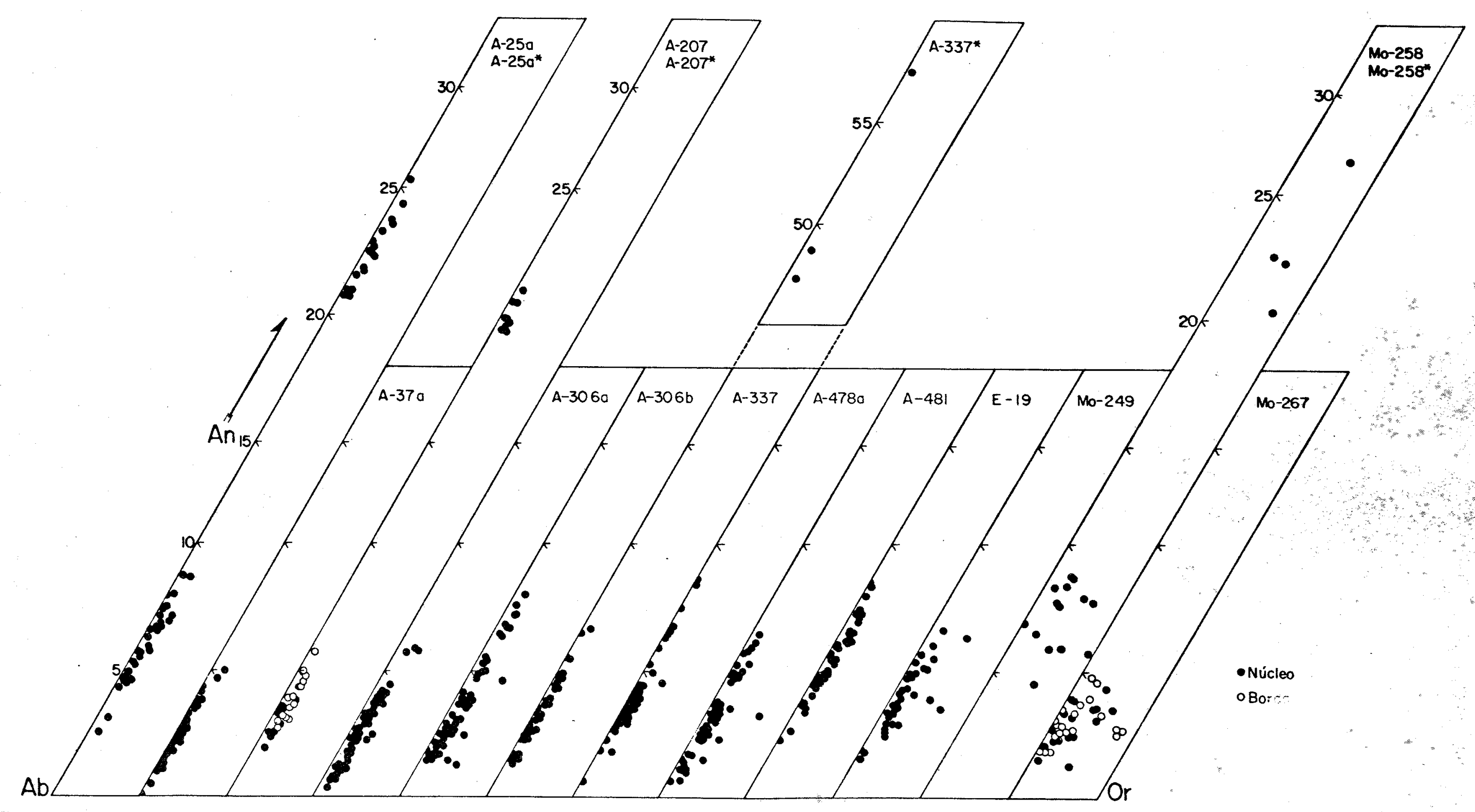

Figura 4 - Diagramas ternários Ab-An-Or para os plagioclásios das diversas amostras de albita an 

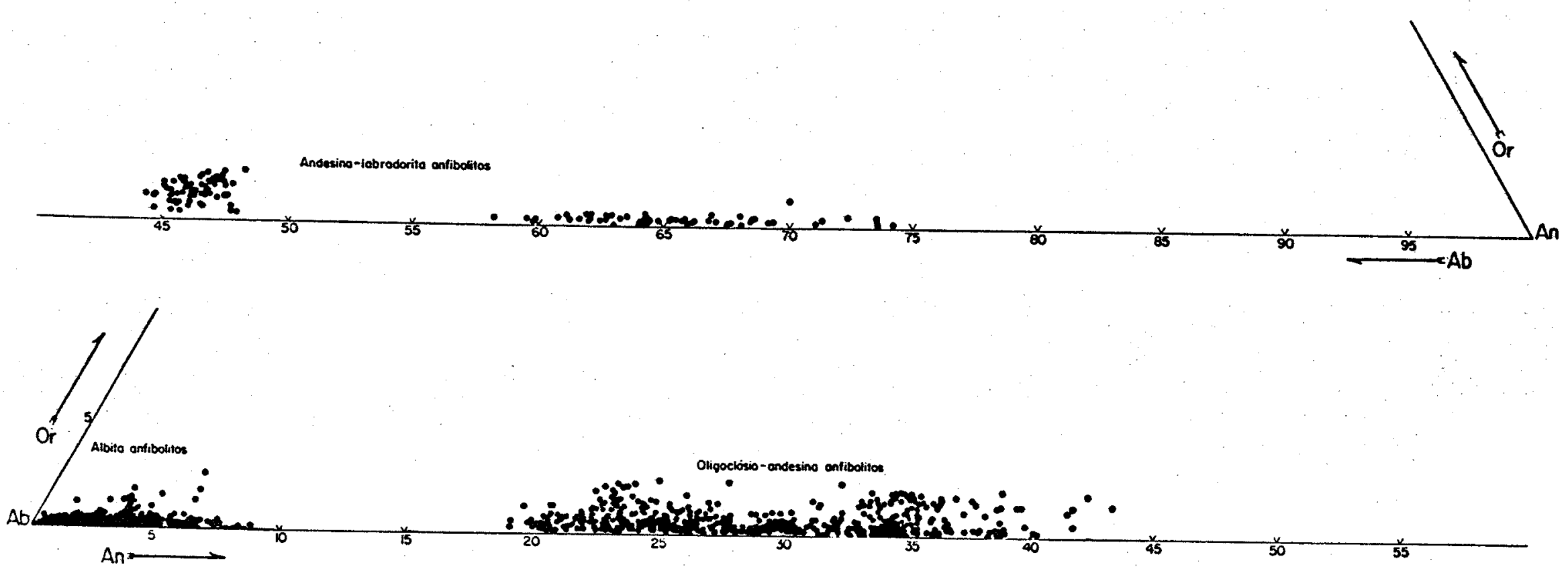

Figura 5 (superior) - Gräfico integrando os dados constantes da Figura 2. Figura 6 (inferior) - Gráfico integrando os dados constantes das Figuras 3 e 4. 


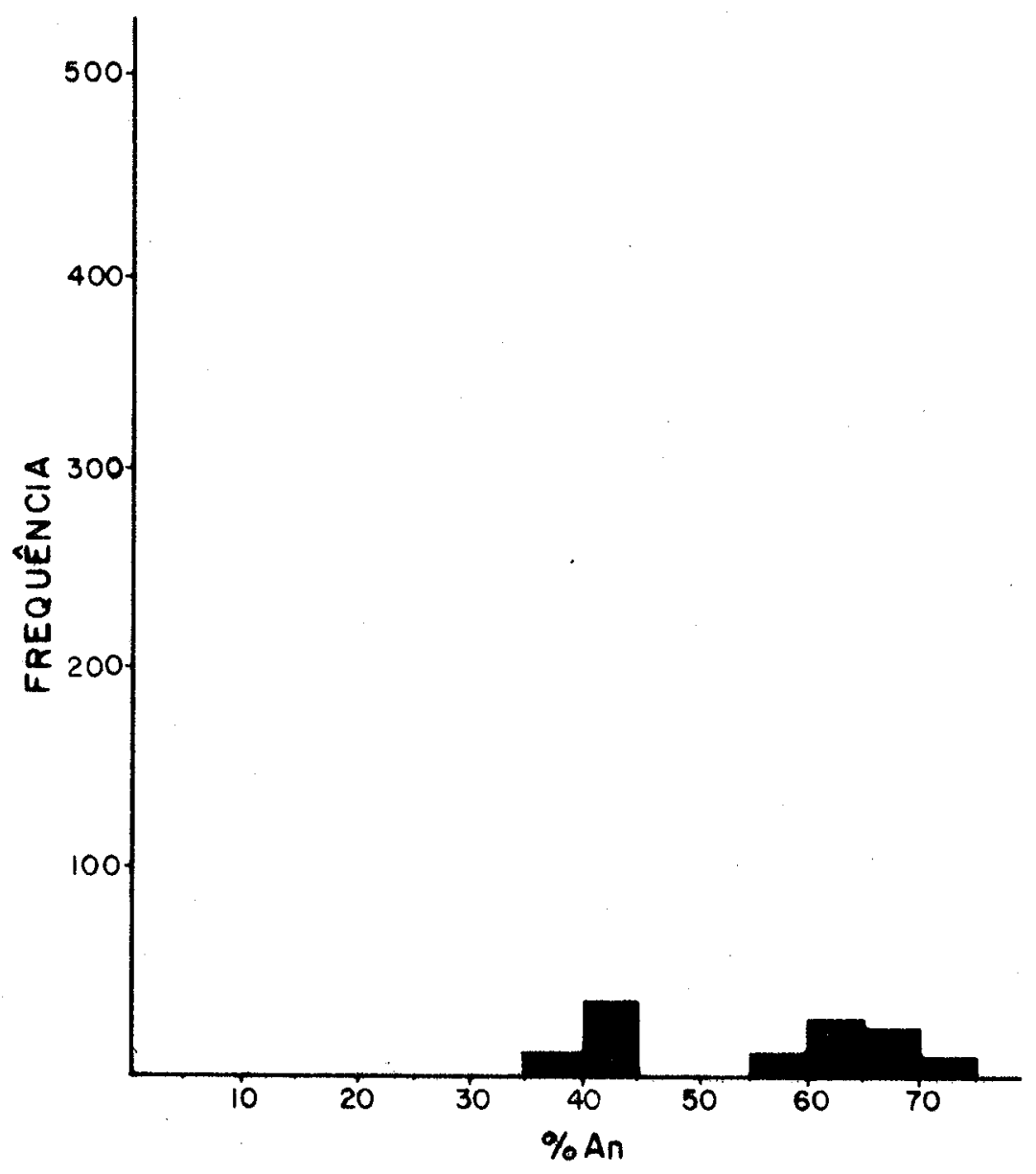

Figura 7 - Histograma de composição para os plagioclásios dos andesina-labradorita anfibolitos.

tos é muito heterogéneo. A amostra Mo-79 possui plagioclásio mais cālcico, de composição labradorítica, com os dados, seja para o núcleo (círculos cheios), seja para as bordas (círculos vasios) dos cristais, mostrando pequena dispersão. Por outro lado, a amostra A-184 apresenta caracteristicas bem diferentes, um plagioclásio mais södico, de natureza andesínica, e forte dispersão dos dados, com uma composição variāvel dentro do in tervalo de 25 a $40 \%$ da molécula de anortita. Como resultado, o seu histograma de composição (Figura 7) apresenta um caräter fortemente bimodal.

No grupo dos oligoclásio-andesina anfibolitos, à exce ção das amostras E-1, E-23 e A-358a (Figura 3), cujas anälises acham-se concentradas dentro de um pequeno intervalo de varia ção composicional, em geral não superior a $5 \%$ do teor de anor tita, as demais apresentam grande dispersão, com os pontos dis tribuindo-se em longas faixas, fato que se reflete no carátér irregular do seu histograma de composição (Figura 8). Determi 
TABELA || $\mid$

Composição química de plagioclásios, expressa em termos dos componentes Ab, An e or, dos albita anfibolitos

\begin{tabular}{|c|c|c|c|c|c|c|c|c|c|}
\hline & $A-25 a$ & $A-25 a *$ & $A-37 a$ & $A-207$ & $A-207 *$ & $A-306 a$ & $A-306 b$ & $A-337$ & $A-337 *$ \\
\hline$A b$ & 93,2 & 78,0 & 97,2 & 96,0 & 79,9 & 96,0 & 96,6 & 96,4 & 48,7 \\
\hline An & 6,5 & 21,6 & 2,7 & 3,7 & 19,7 & 3,6 & 3,0 & 3,4 & 50,9 \\
\hline or & 0,3 & 0,4 & 0,1 & 0,3 & 0,4 & 0,4 & 0,4 & 0,2 & 0.4 \\
\hline & $A-478 a$ & $A-481$ & & $E-19$ & $M O-249$ & Mo- 258 & \multicolumn{2}{|c|}{ Mo- -258 * } & Mo-267 \\
\hline$A b$ & 95,7 & 96,5 & & 94,1 & 95,3 & 91,5 & \multicolumn{2}{|c|}{75,4} & 96,4 \\
\hline An & 4,2 & 3,2 & & 5,7 & 4,2 & 7,3 & \multicolumn{2}{|c|}{22,1} & 2,9 \\
\hline or & 0,1 & 0,3 & & 0,2 & 0,5 & 1,2 & \multicolumn{2}{|c|}{2,5} & 0,7 \\
\hline
\end{tabular}

*Fases coexistentes 


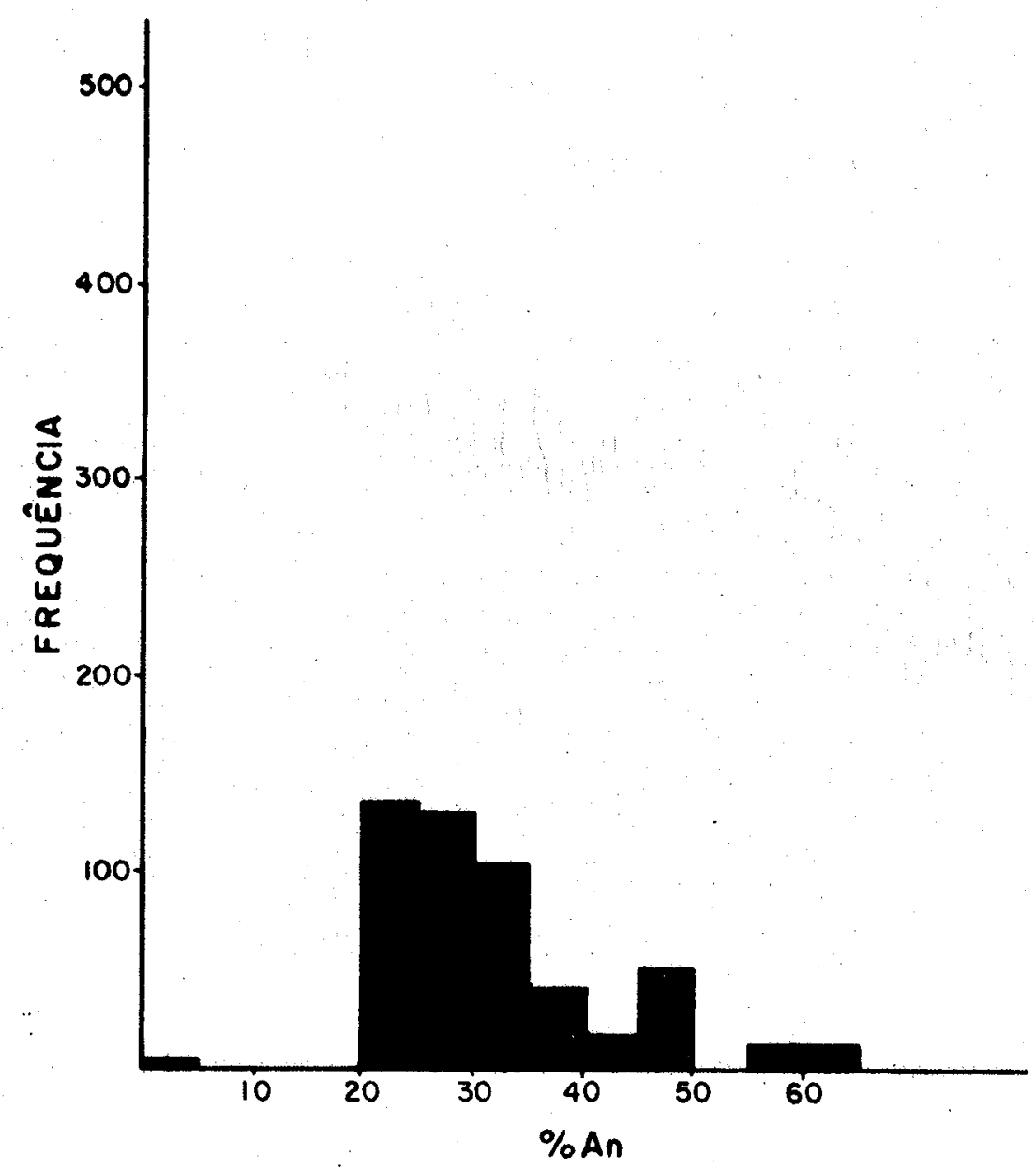

Figura 8 - Histograma de composição para os plagioclásios dos oligoclásio-andesina anfibolitos.

nações feitas separadamente nas bordas e nūcleo de cristais de algumas amostras demonstram que esses minerais são quimicamente homogêneos na escala de grãos.

A Figura 4 reüne os dados analiticos referentes aos plagioclásios do grupo litológico albita anfibolitos. Para a maior parte das anālises, tem-se uma dispersão pequena de pon tos, que tendem a se concentrar no intervalo 90-95\% de anorti ta. Este fato acha-se plenamente salientado no histograma da Figura 9. A julgar pelos dados coligidos para as amostras A-207 e Mo-267, esses minerais são quimicamente homogêneos, não apre sentando portanto zoneamento.

Os resultados analiticos confirmam, em linhas gerais, as observaçóes feitas por métodos öpticos para os grupos litoló gicos de baixo e mëdio grau de metamorfismo. No entanto, o mes mo não se verifica com as amostras do grupo de mais alto grau, 
TABELA IV

Composição química média das diferentes fases de plagiocläsios de anfibolitos da região de Morretes - Antonina

\section{Albita anfibolitos}

$0 l i g o c l a ̈ s i o-a n d e s i n a ~ a n f i b o l i t o s$

$\mathrm{Ab}$

An

or

95,4
4,3
0,3

75,0

25 ,

68,2

61,9

52,9

$(64,5)$

$37,7 \quad 45,8 \quad(34,9)$

$\begin{array}{lllll}0,4 & 0,4 & 0,4 & 1,3 & (0,6)\end{array}$

Andesina-labradorita anfibolitos 


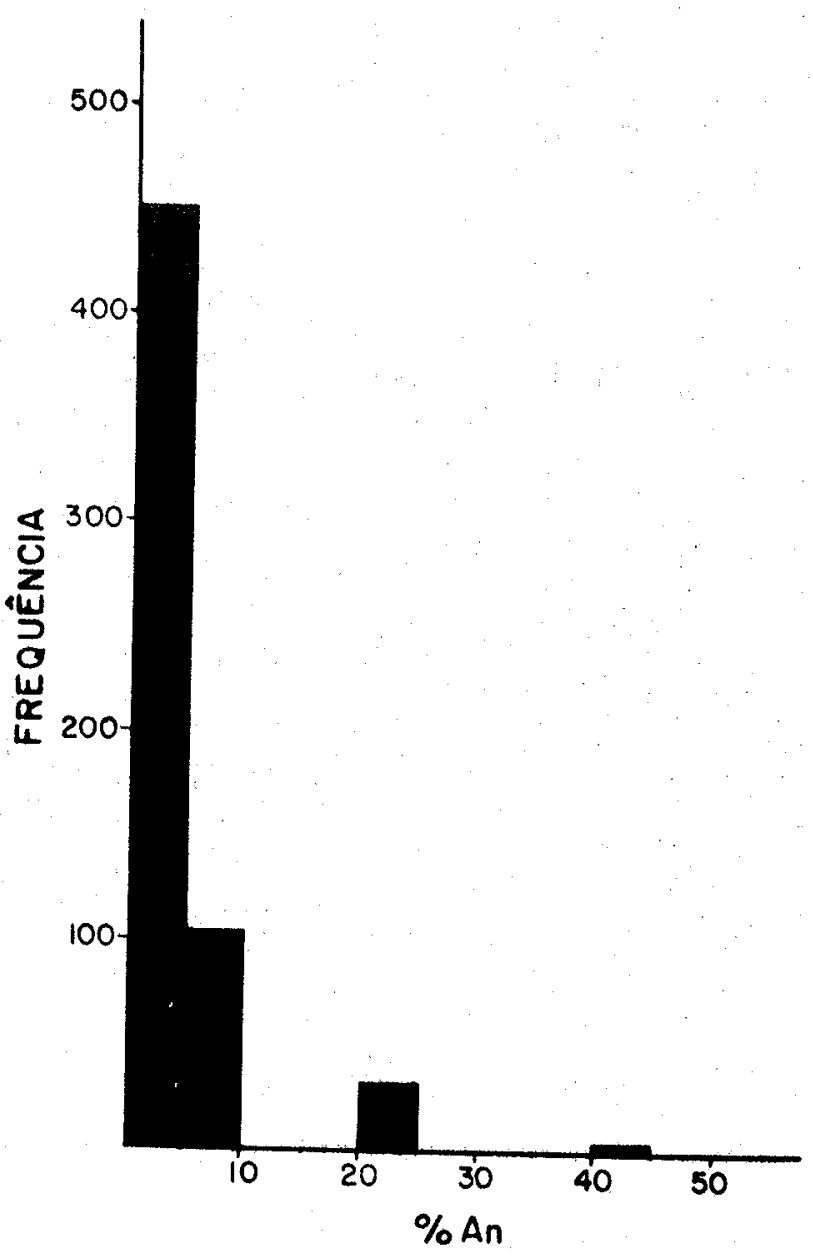

Figura 9 - Histograma de composição para os plagioclásios dos albita anfibolitos.

os andesina-labradorita anfibolitos, em que se obteve valores discordantes daqueles conseguidos por GIRAROI $(1969,1971)$ para as duas amostras investigadas, Mo-79 e A-184.

Uma vez reunidos (Figuras 5 e 6 ), os dados indicam cla ramente que, embora o campo de variação composicional dos plá giocläsios seja extremamente amplo $\left(A_{0-75}\right)$, a distribuição dos pontos não se faz de maneira contínua, havendo uma interrupção nitida no intervalo compreendido entre $A_{8}$ e $A_{2} n_{20}$. Essa carên cia de dados pode ser também vista no histograma da Figura 10 , reunindo as informações constantes dos histogramas individuais para cada grupo litológico (Figuras 7 a 9). A aparente falta de dados para o intervalo An $50-55$ encontra justificativa na amostragem precäria dos andesina-labradorita anfibolitos, com apenas duas amostras analisadas. 


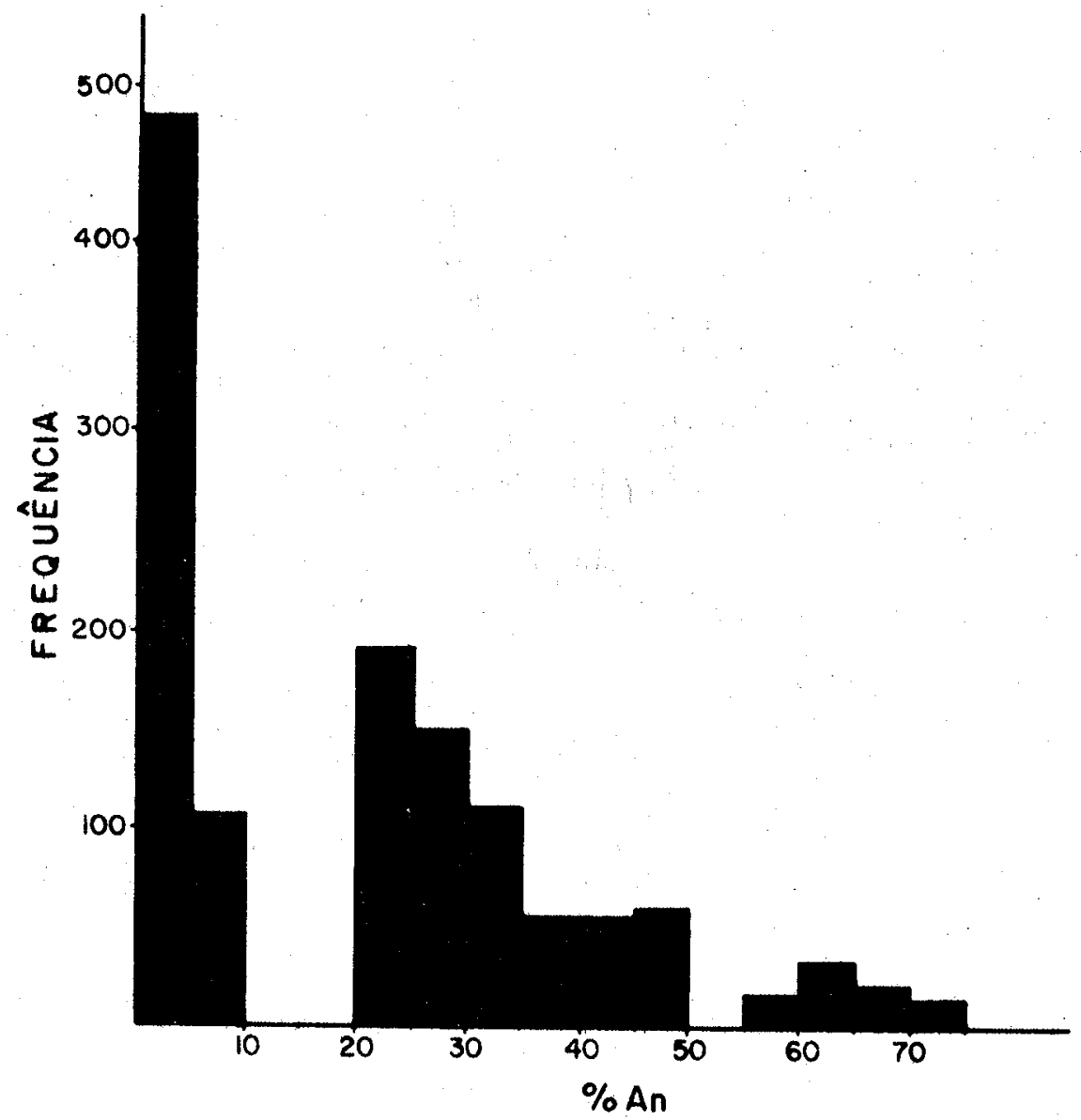

Figura 10 - Histograma de composição integrando os dados referentes aos andesina-labradorita, oligoclásio-andesina e albita anfibolitos.

Värios autores tentaram explicar c hiato acima $\left(\mathrm{An}_{8-20}\right)$, tão frequente em plagioclásios de rochas metamórficas, destá cando-se entre eles CHAO e TAYLOR (1940), RAMBERG (1944), LAVES (1954), GAY e SMITH (1955), CHRISTIE (1959) e NOBLE (1962). Das explicações apresentadas, as que mais encontram adeptos são as de CHRISTIE (1959) e NOBLE (1962). Estes autores, baseando-se em modificações do diagrama de estabilidade plagioclásio-epído to de RAMBERG (1944), concluiram que, em condições de temperá tura decrescente, o plagioclásio tende a formar membros cada vez mais sódicos, originando paralelamente epídoto às expensas das moléculas de anortita liberada durante a reação. Uma vez a temperatura tenha atingido um determinado valor, o plagiocla sio se desmistura e a fase cálcica reage com o epidoto formando albita + epídoto, momento em que a temperatura continua novamen te a decrescer. 
Em resumo, a ausência de plagioclásios com composição situada no intervalo $A_{5-20}$ é interpretada como o resultado de um processo de desmisturação das moléculas de albita e anortita em condições de baixa temperatura, disso resultado minerais hete rogêneos denominados "peristerite" (BOGGILD citação em CHRISTIE, 1959). Segundo CHRISTIE (1959), esse campo de imiscibilidade es taria compreendido entre $\mathrm{An}_{5}$ e $\mathrm{An}_{20}$.

A Tabela IV mostra que o grupo dos oligoclásio-andesina anfibolitos é quimicamente o mais heterogêneo, a ponto de ser possivel reconhecer-se quatro fases mineralógicas coexistentes, a julgar pelo seu teor em anortita. Por outro lado, o grupo dos albita anfibolitos contêm tão somente uma ünica fase. Quando com parados os valores médios para os três grupos, tem-se uam idéia mais concreta dessas diferenças, passando-se de um plagiocläsio mais cálcico (andesina-labradorita anfibolitos) para uma fase in termediāria (oligoclásio-andesina anfibolitos) e, finalmente, um plagioclásio sódico (albita-anfibolitos).

Feldspatos potássicos - Estes minerais aparecem esporadicamente nos anfibolitos da região, sendo a sua presença reconhecida em pelo menos sete das amostras investigadas.

A exceção da amostra E-23, eles possuem pequenas dimen sões e estão presentes em quantidades reduzidas nas rochas. A sua identificação somente foi possível com o auxílio da micros sonda eletrónica, motivo pelo qual não constam das tabelas de anālises modais.

Foram efetuadas anälises em sete amostras, com os dados químicos parciais constando da Tabela V. A distribuição dos pon tos correspondentes à composição desses minerais, expressa em função das molëculas de albita-anortita-ortocläsio, ē vista na Figura 11 .

Dentre as amostras examinadas, uma se destaca das de 


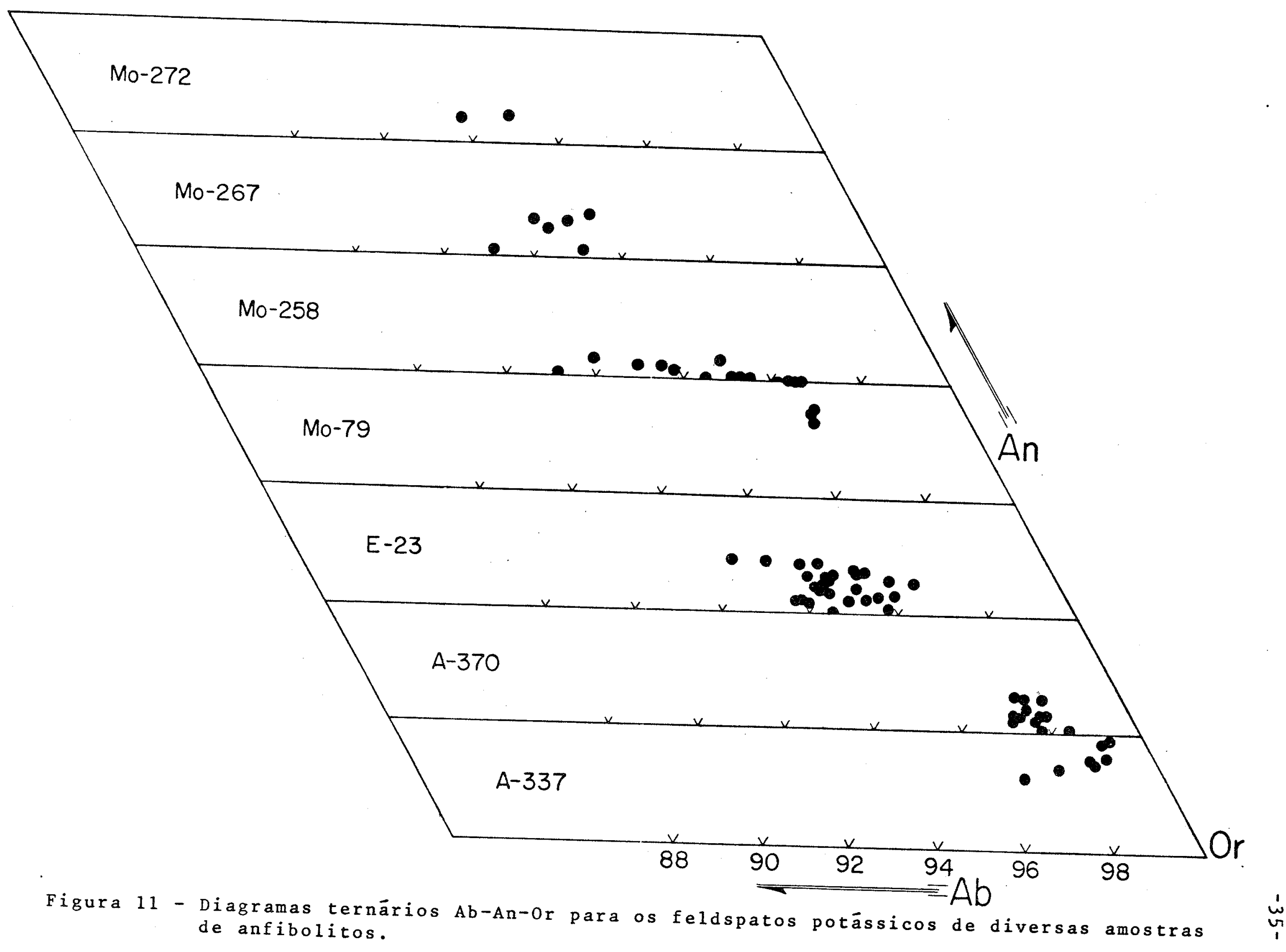


TABELA V

Análises químicas parciais de feldspatos potássicos, expressas em função dos componentes molecula res Albita, Anortita e Ortoclásio

$\begin{array}{cccc} & \text { Ab } & \text { An } & \text { Or } \\ A-337 & 1,5 & 3,3 & 95,2 \\ \text { A-370 } & 2,0 & 0,6 & 97,4 \\ \text { E-23 } & 5,0 & 0,7 & 94,3 \\ \text { Mo-79 } & 3,8 & 2,4 & 93,8 \\ \text { Mo-258 } & 5,5 & 0,1 & 94,4 \\ \text { Mo-267 } & 7,2 & 0,7 & 92,1 \\ \text { Mo-272 } & 7,2 & 0,7 & 92,1\end{array}$


mais por corresponder a um tipo peculiar de rocha, com caracte rísticas que se afastam totalmente das exibidas pelos três gru pos de anfibolitos anteriormente descritos. Trata-se de uma ro cha contendo, ao lado de hornblenda e plagioclásio, feldspato po tāssico como constituinte mineralögico principal. A sua anāise modal, constante da Tabela VI, mostra que a porcentagem desse mi neral é muito alta, aproximando-se do valor obtido para os pla gioclàsios.

\section{TABELA VI}

Anälise modal do anfibolito E-23

$\begin{array}{lr}\text { Hornblenda } & 45,0 \\ \text { Plagioclásio } & 22,3 \\ \text { Feldspato potässico } & 18,2 \\ \text { Epídoto } & 8,7 \\ \text { Clorita } & 2,2 \\ \text { Opacos } & 0,3 \\ \text { Apatita } & 0,7 \\ \text { Titanita } & 0,8 \\ \text { Biotita } & 1,7\end{array}$

0 exame dos resultados acima evidencia também que esse anfibolito contēm apatita, titanita e opacos como acessórios, apa recendo clorita e epídoto, oriundos da alteração da hornblenda e do plagioclāsio, como minerais secundārios mais comuns.

o feldspato potássico acha-se representado por um micro clínio, por vezes geminado em grade, em geral límpido e sem o me nor indicio de alteração, o que parece sugestivo de que represen ta o produto de uma cristalização tardia. 0 plagiocläsio apre senta-se muito saussuritizado, sendo aparentemente representado por dois tipos (Tabelas II a IV), um mais cālcico, de composição olígoclásio, e outro mais sódico, uma albita, proveniente da transformação do primeiro e presente em pequena quantidade. Ep 
doto ocorre em quantidades razoāveis, mostrando-se na forma de bastonetes muito finos, e em íntima associação com o plagioclā sio. Do ponto de vista genético, a existência de clorita, epído to e albita, formados secundariamente a partir do plagioclásio (oligoclásio) e da hornblenda, bem como a presença de hornblenda como ünico anfibölio, são responsäveis por uma assemblēia típica de uma rocha preliminarmente afetada por um processo mörfico, que, no entanto, não chegou a atingir maior intensida de como indicado pela ausência de actinolita.

Poder-se-ia classificar a amostra em questão (E-23) co mo um microclínio anfibolito, e caracterizar-se, assim, mais um grupo de anfibolitos em adição aos três já definidos para a re gião; contudo, o fato de se tratar de uma ünica ocorrência, ao la do da rocha exibir feições mineralögicas (excetuando-se obviamen te o teor de feldspato potássicol e texturais comuns às demais va riedades da àrea, parecem desaconselhar tal. procedimento. Em termos de gradiente metamörfico, a associação mineralögica encon trada é condizente com a fäcies anfibolito de grau médio de TURNER e VERHOOGEN (1960) e TURNER (1968).

A presença de feldspato potássico na amostra E-23 pare ce estar relacionada a um processo de metassomatose, com a in trodução de potássio tendo lugar após a formação da rocha, como sugerido por feições mineralógicas e texturais. Esse metassoma tismo, que atingiu maior intensidade junto à amostra em questão, não se restringiu, no entanto, a apenas um ünico local, existin do evidências espalhadas por toda a área.

E possível que esses fenômenos metassomäticos estejam geneticamente associados aos corpos graníticos da Graciosa e do Marumbi .

Anfibólios - Como citado previamente, os anfibolitos de Morretes-Antonina foram agrupados de conformidade com a natureza do seu plagiocläsio. Tambēm foi mencionado que os anfibölios mudam as suas propriedades ópticas à medida que o teor de anorti ta daqueles minerais sofre qualquer variação. A caracterização 
desses anfibólios foi efetuada por GIRARDI (1969, 1971) com base nas suas propriedades öpticas, e recorrendo ao gräfico de SHIDO e MIYASHIRO (1959), que separa os campos da hornblenda e da act nolita a partir dos valores de $2 \mathrm{~V}$ e $\mathrm{N}_{Y}$.

A presença de hornblenda como único anfibölio de um gru彑 po especifico de anfibolitos, a ocorrēncia de actinolita como mi neral principal em outros, assim como a existência de núcleos de hornblenda circundados por actinolita, indicam que os anfiboli tos da região se formaram em condições variāveis de metamorfís mo.

0 estudo dos anfibölios, efetuado inicialmente com base em dados öpticos, foi ampliado, contando-se agora com os dados referentes à química mineral. Assim, foram examinadas as amos tras investigadas anteriormente por GIRARDI (1969, 1971), acres cidas de cinco outras coletadas recentemente.

A exemplo do sucedido com os feldspatos, as anälises químicas dos anfibölios foram realizadas utilizando-se a tēcnica da microssonda eletrônica, com os dados obtidos constando das Tabelas VII, VIII e $X$. Esses valores representam a mëdia resul tante da anālise de cerca de quarenta grãos do mineral em cada amostra de rocha. Dados referentes à förmula química dos anfibó lios, expressa na base de vinte e três ätomos de oxigênio, acham-se reunidos, respectivamente, nas Tabelas VII, $I X$ e XI. A com pasição química média dos anfibólios para os três grupos de anfi bolitos è fornecida na Tabela XII.

Discussão dos Resultados - Coube a LEAKE (1968), a proposição de uma nova nomenclatura para os anfibólios, onde anfibólios calcí feros são definidos como sendo aqueles trazendo, em sua förmula unitäria, 1,5 ou mais átomos de cālcio; por outro lado, anflboo lios subcalcíferos contêm entre 1,0 e 1,5 àtomos de cálcio. 0 sistema propōs a subdivisão dos anfibólios em diversos campos de composição, usando-se como parâmetros de classificação as pro porções das seguintes variáveis (dados extraídos da fórmula quí 
TABELA VII

Composição química parcial de anfibōlios dos andesina-labradorita anfibolitos da região de Morretes - Antonina

$\begin{array}{lcc}\mathrm{SiO}_{2} & \mathrm{Mo}-79 & \mathrm{~A}-184 \\ \mathrm{TiO}_{2} & 43,4 & 44,3 \\ \mathrm{Al}_{2} \mathrm{O}_{3} & 1,66 & 1,58 \\ \mathrm{FeO}^{*} & 11,2 & 12,8 \\ \mathrm{MnO} & 14,3 & 15,5 \\ \mathrm{MgO} & 0,23 & 0,23 \\ \mathrm{CaO} & 11,2 & 9,04 \\ \mathrm{Na}_{2} \mathrm{O} & 12,5 & 12,2 \\ \mathrm{~K}_{2} \mathrm{O}^{\mathrm{N} O} & 1,27 & 1,46 \\ \mathrm{Total} & 1,24 & 0,42 \\ \mathrm{TaO} & 97,00 & 97,53\end{array}$

* Fe calculado como Feo

Förmula química, expressa na base de 23 àtomos de oxigênio, e nümero de NIGGLI $\mathrm{mg}$

$\begin{array}{lll} & M 0-79 & A-184 \\ \mathrm{Si} & 6,509 & 6,574 \\ \mathrm{Al} \text { iv } & 1,491 & 1,426 \\ \mathrm{Al} \text { i } & 0,488 & 0,813 \\ \mathrm{Ti} & 0,187 & 0,176 \\ \mathrm{Fe} & 1,794 & 1,923 \\ \mathrm{Mn} & 0,029 & 0,028 \\ \mathrm{Mg} & 2,504 & 1,999 \\ \mathrm{Ca} & 2,009 & 1,939 \\ \mathrm{Na} & 0,369 & 0,420 \\ \mathrm{~K} & 0,237 & 0,079 \\ & & \\ \mathrm{Z} & 8,000 & 8,000 \\ \mathrm{Y} & 5,002 & 4,939 \\ \mathrm{X} & 2,615 & 2,438 \\ \mathrm{mg} & 0,58 & 0,51\end{array}$


mica estrutural): $\mathrm{Si}, \mathrm{Ca}+\mathrm{Na}+\mathrm{K}, \mathrm{Ti}$ e relação $\mathrm{Mg} / \mathrm{Mg}+\mathrm{Mn}+\mathrm{Fe}^{3+}$ $+\mathrm{Fe}^{2+}$ (nümero de $\mathrm{Niggli} \underline{\mathrm{mg}}$ ).

0 exame dos resultados apresentados permite concluir, segundo LEAKE (1968), que todos os minerais analisados correspon dem a anfibólios calcíferos, visto que apresentam em sua förmula química (Tabelas VII, IX e XI) nümero de àtomos de cälcio supe rior ao limite definido acima. Por outro lado, à exceção de al gumas amostras, a maior parte contém valores inferiores a 2,0 átomos de cālcio por fórmula unitāria, obedecendo-se, assim, o limite superior estabelecido por HALLIMOND (1943) para esse gru po de minerais:

A caracterização química desses minerais ē feita tám bẻm com base no gräfico de DEER et al. (1963). Assim,a projé ção dos valores de $\mathrm{Na}+\mathrm{K}$ e $\mathrm{Al}^{\mathrm{i}}$ V (Figura 12) possibilita situar os anfibólios analisados em dois campos distintos de composição. o primeiro ocupa a porção superior do campo da hornblenda, com os pontos voltados ligeiramente no sentido do campo da pargasita. Nessa região, à exceção apenas de duas amostras, acham-se local i zadas as amostras relativas aos anfibölios pertencentes aos gru

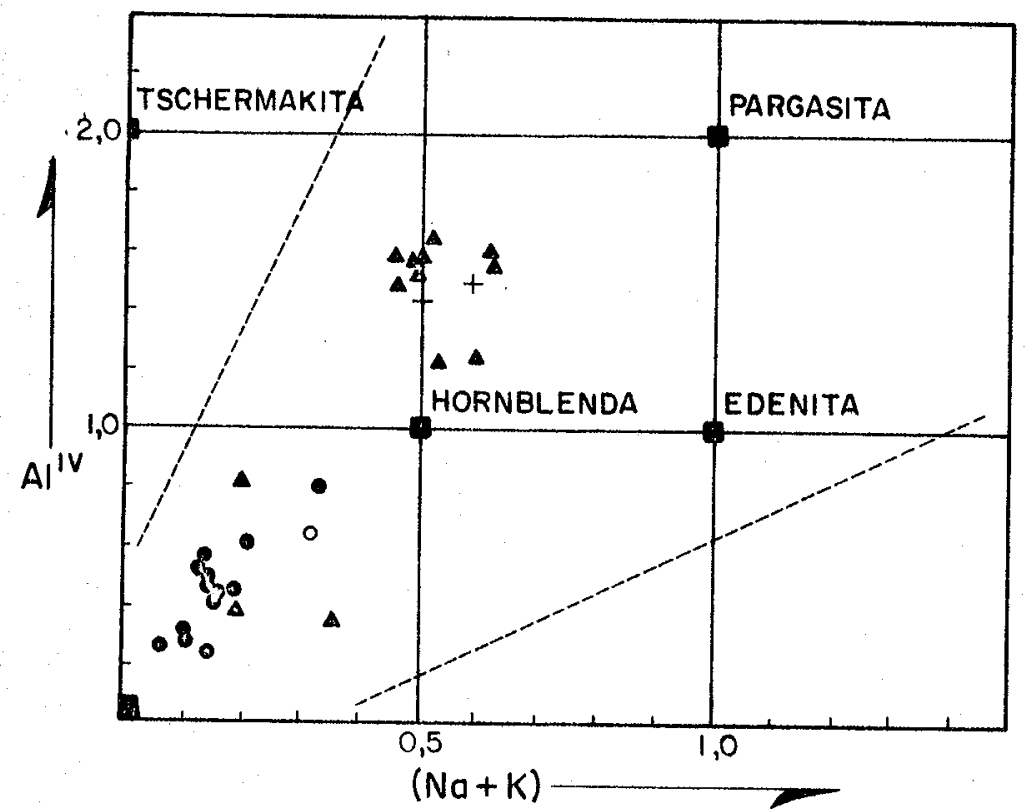
Figura 12 - Gráfico reunindo os valores de $N a+K$ e Al $1 \mathrm{~V}$ para os
anfibólios investigados.

Simbologia (tambēm adotada para as Figuras 13 a 17): + , andesina-labradorita anfibolitos; $\Delta, 01$ igoclasio-andesina anfibo litos ( $\Delta$, borda cristal zonado); o, albita anfibolitos(o,borda cris tal zonado). 
TABELA VIII

Composição quimica parcial de anfibölios dos oligoclásio-andesina anfibolitos da região de Morretes - Antonina

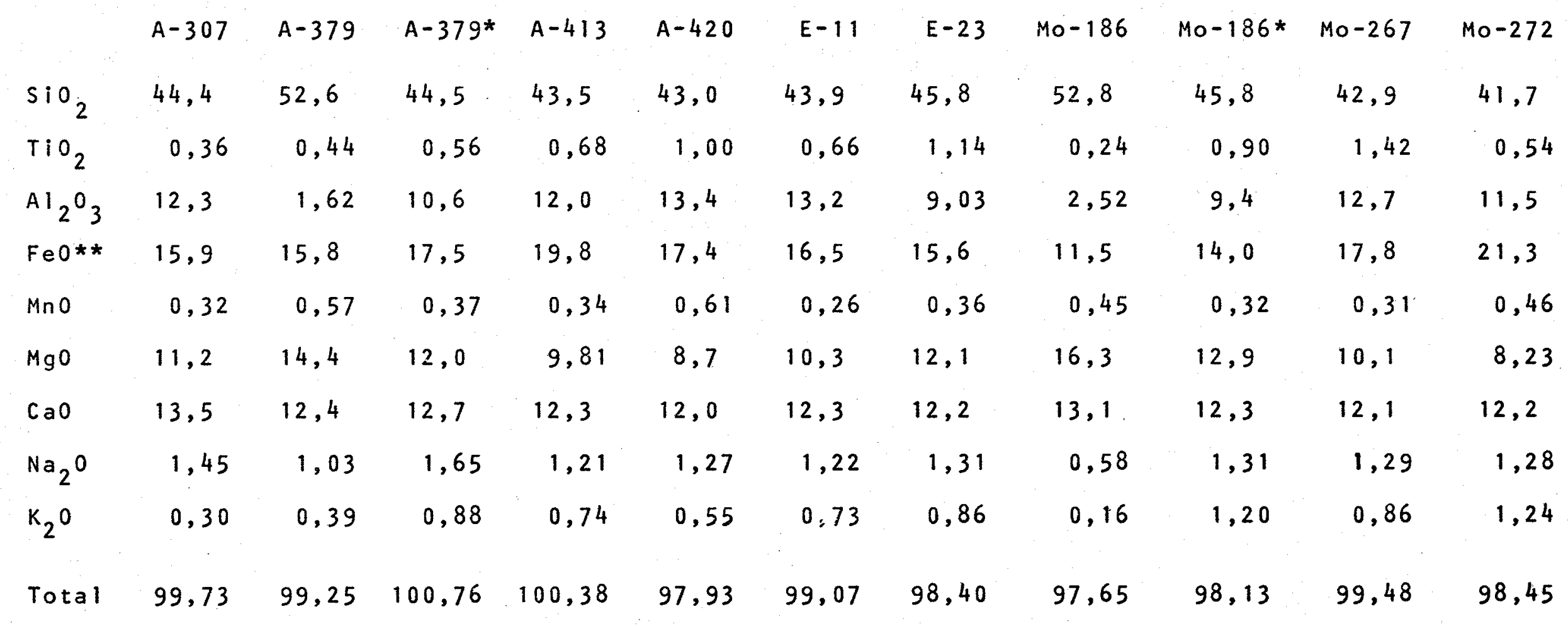

* Fases coexistentes

**Fe calculado como FeO 
TABELA IX

Förmula estrutural, expressa na base de 23 ätomos de oxigênio, dos anfibólios dos oligoclásio-andesi na anfibolitos, e nümero de NIGGLI $\underline{\mathrm{mg}}$

\begin{tabular}{|c|c|c|c|c|c|c|c|c|c|c|c|}
\hline & $A-307$ & $A-379$ & $A-379 *$ & $A-413$ & $A-420$ & $E-11$ & $E-23$ & Mo- 186 & Mo-186* & Mo-267 & Mo- 272 \\
\hline Si & 6,487 & 7,636 & 6,511 & 6,433 & 6,435 & 6,459 & 6,772 & 7,618 & 6,753 & 6,351 & 6,389 \\
\hline$A I^{I V}$ & 1,513 & 0,364 & 1,489 & 1,567 & 1,565 & 1,541 & 1,228 & 0,382 & 1,247 & 1,649 & 1,611 \\
\hline$A I^{v i}$ & 0,606 & - & 0,340 & 0,524 & 0,799 & 0,489 & 0,346 & 0,046 & 0,386 & 0,567 & 0,465 \\
\hline $\mathrm{Ti}$ & 0,040 & 0,048 & 0,061 & 0,075 & 0,113 & 0,073 & 0,127 & 0,026 & 0,100 & 0,158 & 0,062 \\
\hline $\mathrm{Fe}$ & 1,942 & 1,918 & 2,141 & 2,449 & 2,178 & 2,030 & 1,929 & 1,387 & 1,726 & 2,204 & 2,729 \\
\hline$M n$ & 0,039 & 0,070 & 0,046 & 0,043 & 0,077 & 0,032 & 0,045 & 0,055 & 0,040 & 0,039 & 0,059 \\
\hline $\mathrm{Mg}$ & 2,439 & 3,116 & 2,617 & 2,162 & 1,940 & 2,259 & 2,667 & 3,505 & 2,835 & 2,229 & 1,879 \\
\hline $\mathrm{Ca}$ & 2,114 & 1,929 & 1,991 & 1,949 & 1,924 & 1,938 & 1,932 & 2,025 & 1.943 & 1,919 & 2,003 \\
\hline $\mathrm{Na}$ & 0,411 & 0,290 & 0,468 & 0,346 & 0,369 & 0,348 & 0,376 & 0,162 & 0,375 & 0,370 & 0,380 \\
\hline K & 0,055 & 0,072 & 0,164 & 0,139 & 0,105 & 0,137 & 0,162 & 0,030 & 0,225 & 0,162 & 0,242 \\
\hline$z$ & 8,000 & 8,000 & 8,000 & 8,000 & 8,000 & 8,000 & 8,000 & 8,000 & 8,000 & 8,000 & 8,000 \\
\hline$Y$ & 5,066 & 5,152 & 5,205 & 5,253 & 5,107 & 4,883 & 5,114 & 5,019 & 5,087 & 5,197 & 5,194 \\
\hline$x$ & 2,580 & 2,291 & 2,623 & 2,434 & 2,398 & 2,423 & 2,470 & 2,217 & 2,543 & 2,451 & 2,625 \\
\hline $\mathrm{mg}$ & 0,55 & 0,61 & 0,54 & 0,46 & 0,46 & 0,52 & 0,57 & 0,71 & 0,60 & 0,50 & 0,40 \\
\hline
\end{tabular}

*Fases coexistentes 
pos dos oligocläsio-andesina e andesina-labradorita anfibolitos. A segunda concentração de pontos ocorre próximo ao campo da tre molita, com as amostras pertencentes, em quase sua totalidade, ao grupo dos albita anfibolitos. A posição relativa desses pontos evidencia o nítido decréscimo nos conteúdos de Al'v, que substi tui si na posição tetraédrica, e àlcalis desses minerais, Por outro lado, existem ainda pontos dispersos entre os dois campos acima, correspondendo a fases coexistentes em anfibolitos de grau mëdio e baixo de metamorfismo.

A anälise dos minerais zonados permite concluir que eles ocupam posições na região intermediāria do diagrama, com os pon tos correspondentes às bordas dos cristais situando-se abaixo dos relativos aos nücleos. Isto mostra que, para uma variação muito pequena em $\mathrm{Na}+K$, o teor em $A l^{i}$ vê-se diminuído do cen tro para a borda dos cristais, refletindo, assim, uma tendência composicional no sentido da tremolita. Cabe, também, realçar que os pontos, no seu conjunto, guardam disposição linear, suge rindo assim a existência de variações gradativas de composição entre os termos hornblenda e tremolita.

A projeção dos dados químicos nos diagramas de LEAKE (1968) é mostrada nas figuras 13 e 14 . 0 exame desses diagramas evidencia que a maioria dos pontos correspondentes aos anfibó lios do grupo dos albita anfibolitos acha-se concentrada no cam po da actinolita, com pequenas incursões estendendo-se atë o da hornblenda actinolitica (Figura 13). As amostras caracterizando os anfibólios das andesina-labradorita anfibolitos situam-se em campos bem distintos, limite magnésio hornblenda e ferro horn blenda (Figura 13) e hornblenda edenitica (Figura 14). 0s gräficos demonstram, tambēm, que o comportamento químico dos anfi bölios dos oligocläsio-andesina anfibolitos estä condicionado ao seu grau de transformação. Nas amostras menos alteradas, o anfibölio é representado por apenas um membro da família, com os pontos correspondentes à composição desses minerais localizando-se nos limites dos campos da hornblenda tschermakitica,hornblen da ferro-tschermakitica e magnésio hornblenda. 


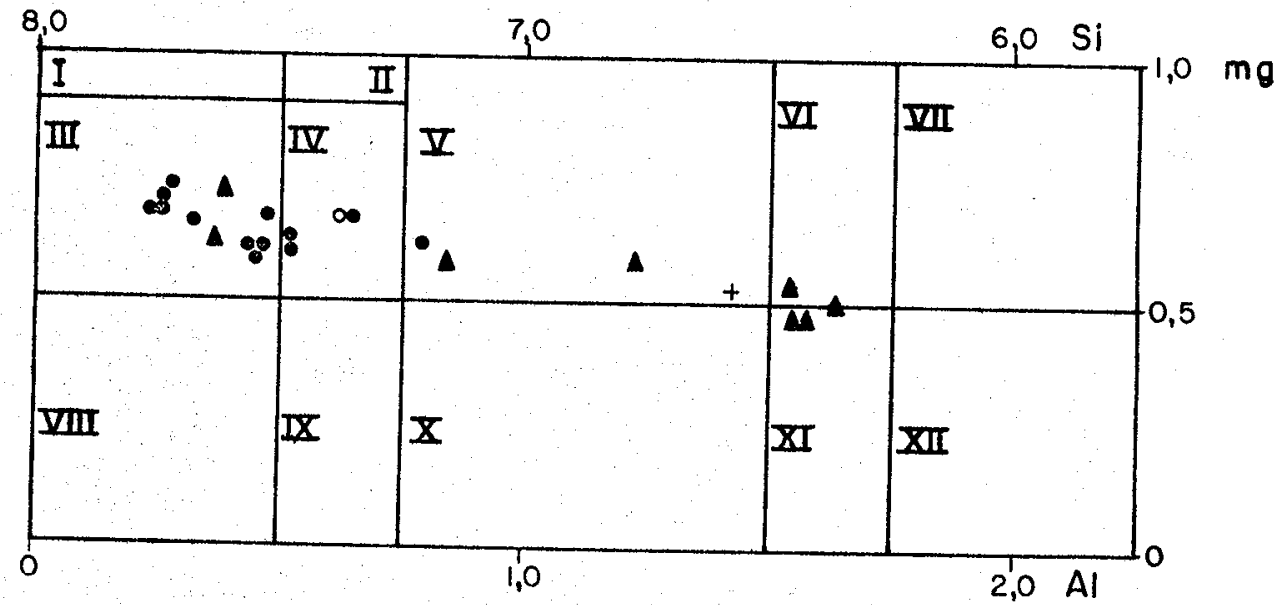

Figura 13 - Diagrama de nomenclatura, proposto por LEAKE (1968), reunindo valores de $\mathrm{Si}, \mathrm{Ca}+\mathrm{Na}+\mathrm{K}, \mathrm{Ti}$ e número de Niggli mg.

I-Tremolita; II-Hornblenda tremolítica; III-Actino lita; IV-Hornblenda actinolítica; V-Magnésio horn blenda; VI-Hornblenda tschermakítica; VII-Tscherma kita; VIII-Ferro actinolita; IX-Ferro hornblenda actinolitica; X-Ferro hornblenda; XI-Ferro hor $\underline{n}$ blenda tschermakitica; XII-Ferro tschermakita.

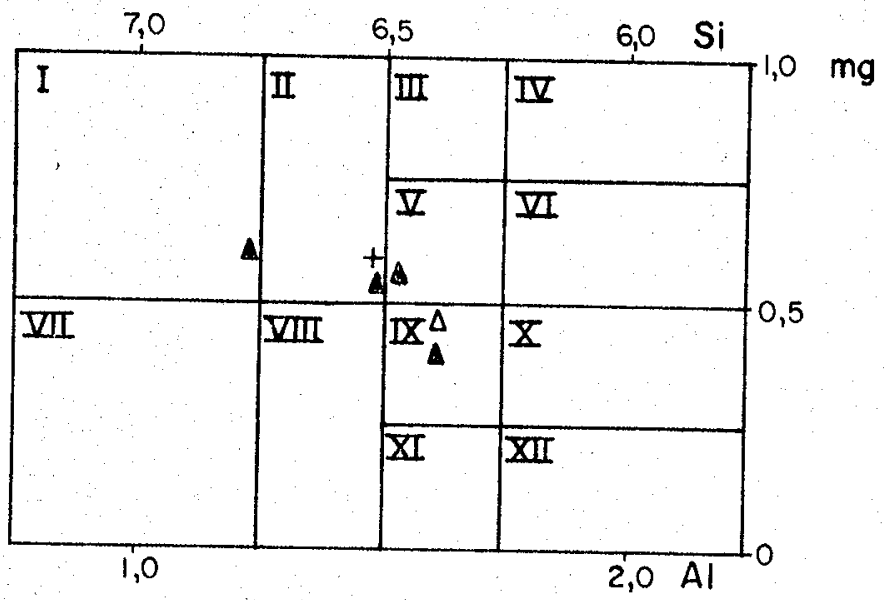

Figura 14 - Diagrama de nomenclatura, proposto por LEAKE (1968), reunindo valores de $\mathrm{Si}, \mathrm{Ca}+\mathrm{Na}+\mathrm{K}, \mathrm{Ti}$ e número de Niggli mg.

I-Edenita; II-Hornblenda edenítica; III-Hornblenda pargasitica; IV-Pargasita; V-Hornblenda pargasíri ca ferrosa; VI-Pargasita ferrosa; VII-Ferro eden ta; VIII-Ferro hornblenda edenítica; IX- Magnésio hornblenda hastingsítica; $X$-Hastingsita magnesia na; XI-Hornblenda hastingsitica; XII-Hastingsita. 
Entretanto, nas rochas mais atingidas pela ação retrometamörfica, dois ou mais tipos de anfibölio ocorrem na mesma amostra, sendo que os pares coexistentes se separam em campos distintos, ou se ja, enquanto que as fases portadoras de baixo teor em Al caem no campo da actinolita (Figura 13) os seus correspondentes alumi nosos dispõem-se segundo um círculo fechado de pequeno raio en globando os limites dos campos da hornblenda edenitica, hornblen da pargasítica ferrosa, magnésio hornblenda hastingsítica e fer ro hornblenda edenítica.

O exame da Figura 15 , reunindo $A l^{i v}$ e $A l^{v i}$, aliado às observações extraídas dos diagramas anteriores, possibilita con cluir que os nūcleos de anfibölio remanescente possuem teores mais altos em $A I^{i V}$ e mais baixos em Si. Isto parece indicativo que, como resultado de mudanças no gradiente metamörfico regio nal, esses minerais tiveram sua composição química modificada, va riando as concentrações de Si e Al ${ }^{i V}$ na posição tetraēdrica. A Figura 15 mostra, ainda, uma separação nítida entre os anfibó lios correspondentes aos três agrupamentos litológicos. Os anfi bölios pertencentes ao grupo dos andesina-labradorita e oligoclä

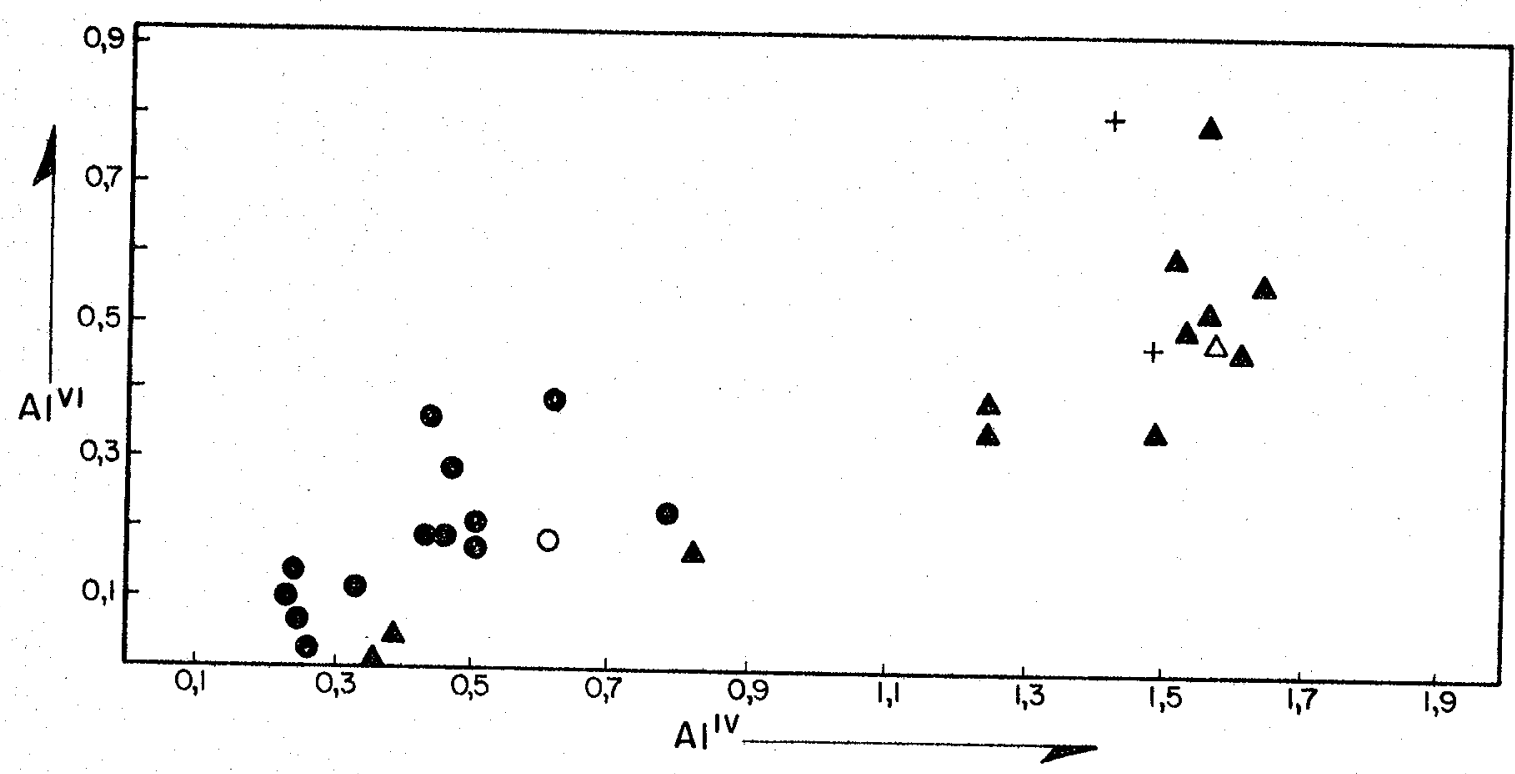

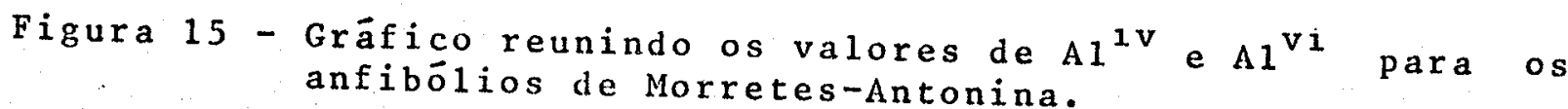


TABELA $X$

Composição química parcial de anfibölios dos albita anfibolitcs da região de Morretes-Antonina

\begin{tabular}{|c|c|c|c|c|c|c|c|c|c|c|c|c|}
\hline & $A-25 a$ & $A-25 a *$ & $A-306 a$ & $A-306 a *$ & $A-306 b$ & $A-306 b *$ & $A-337$ & $A-481$ & $E-19$ & Mo-249 & Mo-249* & Mo-250a \\
\hline $\mathrm{SiO}_{2}$ & 53,3 & 50,5 & 54,0 & 51,9 & 54,5 & 52,1 & 51,4 & 51,8 & 52,1 & 53,8 & 51,5 & 54,5 \\
\hline $\mathrm{TiO}_{2}$ & 0,16 & 0,24 & 0,13 & 0,25 & 0,19 & 0,39 & 0,14 & 0,19 & 0,16 & 0,19 & 0,18 & 0,08 \\
\hline $\mathrm{Al}_{2} \mathrm{O}_{3}$ & 2,56 & 5,96 & 2,07 & 3,69 & 2,29 & 3,97 & 4,71 & 4,26 & 4,50 & 1,61 & 3,67 & 1,94 \\
\hline $\mathrm{FeO} * *$ & 14,0 & 12,0 & 12,9 & 15,2 & 12,9 & 15,6 & 14,2 & 15,1 & 12,2 & 10,5 & 15,5 & 12,6 \\
\hline MnO & 0,27 & 0,29 & 0,36 & 0,30 & 0,27 & 0,31 & 0,41 & 0,29 & 0,30 & 0,39 & 0,40 & 0,25 \\
\hline $\mathrm{MgO}$ & 15,3 & 14,1 & 15,7 & 13,5 & 15,7 & 13,8 & 12,5 & 13,9 & 15,1 & 17,2 & 13,1 & 16,7 \\
\hline $\mathrm{CaO}$ & 12,5 & 12,7 & 12,5 & 12,7 & 12,5 & 12,7 & 12,7 & 12,7 & 12,5 & 13,3 & 12,7 & 12,6 \\
\hline $\mathrm{Na}_{2} \mathrm{O}$ & 0,30 & 0,61 & 0,50 & 0,52 & 0,35 & 0,45 & 0,61 & 0,41 & 0,47 & 0,36 & 0,52 & 0,22 \\
\hline $\mathrm{K}_{2} \mathrm{O}$ & 0,12 & 0,20 & 0,03 & 0,07 & 0,07 & 0,11 & 0,20 & 0,12 & 0,09 & 0,02 & 0,07 & - \\
\hline
\end{tabular}

$\begin{array}{lllllllllllll}\text { Total } 98,51 & 96,60 & 98,19 & 98,13 & 98,77 & 99,43 & 96,87 & 98,77 & 97,42 & 97,37 & 97,64 & 98,89\end{array}$

* Fases coexistentes

**Fe calculado como FeO 
TABELA XI

Förmula estrutural, expressa na base de 23 àtomos de oxigênio, dos anfibólios dos albita anfibolitos, e numero de NIGGLI $\mathrm{mg}$

\begin{tabular}{|c|c|c|c|c|c|c|c|c|c|c|c|c|}
\hline & $A-25 a$ & $A-25 a *$ & $A-306 a$ & $A-306 a *$ & $A-306 b$ & $A-306 b *$ & $A-337$ & $A-481$ & $E-19$ & Mo-249. & Mo-249* & Mo-250a \\
\hline Si & 7,668 & 7,373 & 7,751 & 7,558 & 7,760 & 7,499 & 7,553 & 7,488 & 7,524 & 7,729 & 7,557 & 7,742 \\
\hline$A I^{i v}$ & 0,332 & 0,627 & 0,249 & 0,442 & 0,240 & 0,501 & 0,447 & 0,512 & 0,476 & 0,271 & 0,443 & 0,258 \\
\hline$A I^{V I}$ & 0,102 & 0,399 & 0,100 & 0,191 & 0,145 & 0,172 & 0,369 & 0,215 & 0,290 & 0,002 & 0,192 & 0,067 \\
\hline$T \mathbf{i}$ & 0,017 & 0,026 & 0,014 & 0,027 & 0,020 & 0,042 & 0,016 & 0,021 & 0,017 & 0,020 & 0,020 & 0,009 \\
\hline $\mathrm{Fe}$ & 1,684 & 1,465 & 1,548 & 1,851 & 1,536 & 1,878 & 1,745 & 1,826 & 1,473 & 1,262 & 1,902 & 1,496 \\
\hline$M n$ & 0,032 & 0,036 & 0,044 & 0,037 & 0,033 & 0,038 & 0,051 & 0,035 & 0,036 & 0,048 & 0,049 & 0,030 \\
\hline $\mathrm{Mg}$ & 3,280 & 3,069 & 3,359 & 2,930 & 3,332 & 2,960 & 2,738 & 2,995 & 3,250 & 3,683 & 2,865 & 3,536 \\
\hline $\mathrm{Ca}$ & 1,926 & 1,986 & 1,922 & 1,981 & 1,907 & 1,958 & 2,000 & 1,967 & 1,934 & 2,047 & 1,997 & 1,917 \\
\hline $\mathrm{Na}$ & 0,084 & 0,173 & 0,139 & 0,146 & 0,096 & 0,126 & 0,173 & 0,114 & 0,131 & 0,100 & 0,148 & 0,060 \\
\hline K & 0,022 & 0,037 & 0,006 & 0,013 & 0,012 & 0,020 & 0,038 & 0,022 & 0,017 & 0,004 & 0,013 & 0,000 \\
\hline$z$ & 8,000 & 8,000 & 8,000 & 8,000 & 8,000 & 8,000 & 8,000 & 8,000 & 8,000 & 8,000 & 8,000 & 8,000 \\
\hline$Y$ & 5,115 & 4,995 & 5,065 & 5,036 & 5,066 & 5,090 & 4,919 & 5,092 & 5,066 & 5,015 & 5,028 & 5,138 \\
\hline$x$ & 2,032 & 2,196 & 2,067 & 2,140 & 2,015 & 2,104 & 2,211 & 2,103 & 2,082 & 2,151 & 2,158 & 1,977 \\
\hline $\mathrm{mg}$ & 0,66 & 0,67 & 0,68 & 0,61 & 0,68 & 0,61 & 0,60 & 0,62 & 0,68 & 0,74 & 0,59 & 0,70 \\
\hline
\end{tabular}


sio-andesina anfibolitos ocupam a porção superior, lado direito, do diagrama, fato decorrente dos seus teores mais elevados em $A I^{I V}$ e $A I^{V i}$. Alguns pontos associados aos oligoclásio-andesina anfibolitos acham-se concentrados na região intermediäria em re lação ao conteüdo de $A I^{\mathfrak{}}{ }^{\mathrm{V}}$, representando, assim, aqueles mine rais do grupo mais afetado pelo evento retrometamórfico. os an fibölios pertencentes ao terceiro grupo, os albita anfibolitos, situam-se na parte inferior, lado esquerdo, do gräfico, tendo por principal característica o seu carāter pouco aluminoso.

A anälise conjunta dos dados químicos (Tabelas VII a XII) permite concluir que os anfibólios das rochas anfibolíticas da ärea de Morretes-Antonina sofreram modificações apreciáveis em sua composição química, como resultado de variações ocorridas nas condições metamörficas regionais. As diferenças químicas existentes, quando comparadas as composições mëdias para os três agrupamentos litolögicos, são muito significativas e apontam no sentido de uma adaptação progressiva desses minerais às novas condições de pressão e temperatura reinantes. Por outro lado,os resultados constantes da Tabela XIl estão a indicar que esse pro cesso de estabilização não chegou a se completar, com as amós tras pertencentes aos grupos dos oligocläsio-andesina e albita anfibolitos mostrando associações mineralögicas em flagrante de sequilibrio, com a formação de diversas fases coexistentes.Esses dados demonstram, também, que o processo de adaptação às condi ções de metamorfismo mais brando se fez acompanhar de uma simpli ficação da composição química (compare-se, por exemplo, a maior complexidade química do anfibólio do grupo dos andesina-labradorita anfibolitos relativamente à fase 4 dos albita anfibolitos), a despeito do nümero maior de fases coexistentes nos albita anfi bolitos.

Se confrontados os anfibölios exibindo composição extre ma (caso das fases 1 e 4, respectivamente, dos andesina-labradorita e albita anfibolitos; Tabela XII), verifica-se que as mudan ças químicas consistiram, essencialmente, de uma diminuição dos teores de $\mathrm{SiO}_{2}, \mathrm{TiO}_{2}, \mathrm{Al}_{2} \mathrm{O}_{3}, \mathrm{FeO}, \mathrm{Na}_{2} \mathrm{O}$ e $\mathrm{K}_{2} \mathrm{O}$, seguida do aumento 


\section{TABELA X $\mid 1$}

Composição química média das fases coexistentes de anfibólios nos diferentes grupos de anfibolitos Andesina-
labradorita 01 igocläsio-andesina anfibolitos Albita anfibolitos anfibolitos

$\begin{array}{ccccccccccc}\text { Fase } & 1 & \text { Fase } 1 & \text { Fase } 2 & \text { Fase } 3 & \text { (Média) } & \text { Fase } 1 & \text { Fase } 2 & \text { Fase } 3 & \text { Fase } 4 & \text { (Média) } \\ 43,9 & 43,0 & 45,0 & 52,7 & (46,9) & 43,8 & 49,1 & 51,5 & 53,7 & (49,6) \\ 1,62 & 0,79 & 0,57 & 0,34 & (0,57) & 0,40 & 0,16 & 0,21 & 0,15 & (0,23) \\ 12,0 & 12,5 & 11,1 & 2,07 & (8,53) & 11,3 & 5,87 & 4,45 & 2,50 & (6,02) \\ 14,9 & 18,6 & 15,5 & 13,7 & (15,9) & 18,4 & 14,3 & 14,3 & 12,5 & (14,9) \\ 0,23 & 0,41 & 0,33 & 0,51 & (0,42) & 0,43 & 0,39 & 0,34 & 0,31 & (0,37) \\ 10,1 & 9,5 & 12,0 & 15,3 & (12,3) & 9,5 & 13,8 & 13,7 & 16,0 & (13,2) \\ 12,3 & 12,4 & 12,6 & 12,8 & (12,6) & 12,2 & 13,0 & 12,7 & 12,6 & (12,6) \\ 1,37 & 1,26 & 1,40 & 0,81 & (1,16) & 1,43 & 0,95 & 0,58 & 0,37 & (0,84) \\ 0,83 & 0,80 & 0,69 & 0,28 & (0,59) & 0,85 & 0,37 & 0,16 & 0,06 & (0,36) \\ 97,25 & 99,26 & 99,19 & 98,51 & (98,97) & 98,31 & 97,94 & 97,94 & 98,19 & (98,12)\end{array}$


concomitante do conteüdo em Mgo, quando passando da fase I (horn blenda tschermakítica) à fase 4 (actinolita). 0s dados da Tabe la XII são, ainda, indicativos que essas modificações se proces saram de forma gradativa, levando ao desenvolvimento de fases intermediārias.

Zoneamento - Uma característica pouco comum aos anfibólios das rochas anfibolíticas da região è a presença de estrutura zonada, visto que no conjunto de amostras analisadas apenas duas apre sentaram essa feição. Preliminarmente, poder-se-ia afirmar que não há qualquer relação entre essas duas rochas, uma vez que, geo graficamente, se situam em pontos distantes, pröximos aos extre mos dos quadrantes NE e SE. Alēm disso, os estudos ópticos reve laram que os seus minerais exibem situações inversas; enquanto a amostra E-5 contém cristais de anfibölio com nücleos claros e bordas verde escuro, a A-478a tem a maior parte da porção cen tral dos seus grãos colorida de verde escuro, algumas vezes ten dendo a marrom, e a periferia mostrando cores mais claras. Além disso, as dimensões dos cristais contribuem para que o zoneamen to da primeira amostra seja bem mais evidente opticamente, oque não ocorre com a segunda, onde os grãos são muito pequenos, dif cultando mesmo por vezes a distinção das duas äreas.

Com o objetivo de se caracterizar quimicamente essa fei ção, foram realizadas anälises com a microssonda eletrônica, ora em pontos alinhados e equidistantes ao longo de um suposto per fil atravessando os cristais, ora em pontos dispersos localiza dos nas bordas dos grãos. Os valores médios correspondentes às bordas e aos núcleos de cada uma das amostras acham-se reunidos na Tabela $x \mid 11$, que, por sua vez, contêm tambēm as förmulas quí micas desses minerais e o seu nümero de Niggli mg.

0 exame dos resultados evidencia que as mudanças de coloração estão diretamente ligadas a variações na composição química desses minerais. Assim, para a amostra E-5, uma vez ado tada a classificação de LEAKE (1968), tem-se um nūcleo de compo 
sição mais magnésio hornblenda e uma borda mais rica em magnẹ sio hornblenda hastingsitica. Quimicamente, essas variações acham-se refletidas, em termos de nücleo $\rightarrow$ borda, na diminuição dos teores de $\mathrm{SiO}_{2}$ e $\mathrm{MgO}$ e aumento concomitante nas concentra ções de $\mathrm{TiO}_{2}, \mathrm{Al}_{2} \mathrm{O}_{3}, \mathrm{FeO}, \mathrm{Na}_{2} \mathrm{O}$ e $\mathrm{K}_{2} \mathrm{O}$. A pequena variação ob servada para o cälcio parece destituída de maior importancia, pois é sabido que esse elemento apresenta um comportamento un forme. Se comparados esses valores com os listados na Tabela $X \mid l$, observa-se que a composição do nücleo caracteriza uma fase mineralögica de transição, em flagrante desequilíbrio químico, e que se identifica mais com os anfibólios actinolíticos comuns aos albita anfibolitos. Por outro lado, a composição da borda corresponde a uma fase guardando grandes similaridades, conquan to o teor de MgO mantenha-se num plano ligeiramente superior, com a magnésio hornblenda dos andesina-labradorita anfibolitos.

Os dados relativos à amostra A-478a apontam para uma situação completamente distinta da anteriormente descrita, com as partes centrais dos cristais apresentando maior riqueza em $\mathrm{TiO}_{2}, \mathrm{Al}_{2} \mathrm{O}_{3}$ e FeO,e maior pobreza em $\mathrm{SiO}_{2}$ e MgO relativamente às bordas. Conquanto essas variações sejam de menor monta, ca racterizando muito mais fases transicionais, sem quimismo defí nido, verifica-se que as composições do nücleo e da borda apró ximam-se mais dos termos actinolíticos, como evidenciado prín cipalmente pelas concentrações de $\mathrm{SiO}_{2}, \mathrm{Al}_{2} \mathrm{O}_{3}$ e Mgo. Se colocá dos dentro do contexto geolögico regional,esses dados guardam perfeita sintonia com o sucedido na ārea, onde são visíveis as evidências da ação de um processo retrometamórfico superimposto ao evento regional. A presença de bordas de composição mais ac tinolítica está a indicar que esses anfibölios reagiram às no vas condições metamórficas reinantes, dando lugar, assim, à for mação de uma associação mineralógica de mais baixo grau de metá morfismo.

No tocante à amostra E-5, os resultados estão apontan do no sentido oposto, ou seja, de uma elevação do gradiente tér mico, como indicado pela natureza mais hornblêndica das bordas 
TABELA XIII

Composição química parcial de anfibólios zonados da região de Morretes - Antonina

\begin{tabular}{|c|c|c|c|c|}
\hline & & & & \\
\hline & Borda & Nücleo & Borda & Nücleo \\
\hline $\mathrm{SiO}_{2}$ & 51,2 & 49,1 & 43,0 & 48,9 \\
\hline $\mathrm{TiO}_{2}$ & 0,09 & 0,16 & 0,46 & 0,29 \\
\hline $\mathrm{Al}_{2} \mathrm{O}_{3}$ & 4,91 & 5,87 & 11,8 & 5,83 \\
\hline $\mathrm{FeO} 0^{*}$ & 12,7 & 14,3 & 18,9 & 16,8 \\
\hline MnO & 0,39 & 0,39 & 0,47 & 0,46 \\
\hline $\mathrm{MgO}$ & 15,1 & 13,8 & 9,91 & 12,1 \\
\hline $\mathrm{CaO}$ & 13,0 & 13,0 & 13,3 & 14,1 \\
\hline $\mathrm{Na}_{2} \mathrm{O}$ & 0,93 & 0,95 & 1,29 & 0.61 \\
\hline $\mathrm{H}_{2} \mathrm{O}$ & 0,37 & 0,37 & 0,68 & 0,22 \\
\hline Total & 98,69 & 97,94 & 99,81 & 99,31 \\
\hline
\end{tabular}

Förmula química, expressa na base de 23 ätomos de oxigênio, e nümero de NIGGLI $\underline{\mathrm{mg}}$

$$
A-478 a
$$$$
E-5
$$

$\begin{array}{lllll} & \text { Borda } & \text { Nücleo } & \text { Borda } & \text { Nücleo } \\ \mathrm{Si} & 7,372 & 7,204 & 6,402 & 7,170 \\ \mathrm{Al}^{\mathrm{IV}} & 0,628 & 0,796 & 1,598 & 0,830 \\ \mathrm{Al}^{\mathrm{Vi}} & 0,205 & 0,219 & 0,473 & 0,177 \\ \mathrm{Ti} & 0,009 & 0,018 & 0,051 & 0,032 \\ \mathrm{Fe} & 1,529 & 1,754 & 2,354 & 2,060 \\ \mathrm{Mn} & 0,048 & 0,049 & 0,059 & 0,057 \\ \mathrm{Mg} & 3,241 & 3,017 & 2,199 & 2,645 \\ \mathrm{Ca} & 2,005 & 2,044 & 2,122 & 2,215 \\ \mathrm{Na} & 0,259 & 0,270 & 0,372 & 0,173 \\ \mathrm{~K} & 0,068 & 0,069 & 0,129 & 0,041\end{array}$

$\begin{array}{lll}Z & 8,00 & 8,00 \\ Y & 5,03 & 5,06 \\ X & 2,33 & 2,38 \\ \mathrm{mg} & 0,67 & 0,63\end{array}$

8,00

8,00

5,14

4,97

2,62

2,43

0,48

0,56 
dos cristais relativamente às suas porções centrais. 0 compor tamento desses anfibólios não se coaduna com o observado em esca la regional, parecendo mais ser o resultado de uma ação metamór fica de caräter localizado.

Minerais opacos - 0 s dois ünicos minerais opacos encon trados nos anfibolitos de Morretes-Antonina foram ilmenita e mag netita (magnetita titanifera numa ünica amostra). Estes mine rais ocorrem invariavelmente nos três grupos de rochas, sendo que nos andesina-labradorita anfibolitos estão presentes em concen trações diminutas.

Ilmenita pode ocorrer isoladamente ou então acompanhada de magnetita. Neste ültimo caso, ela se faz presente em propor ção bem maior que a da magnetita, atingindo muitas vezes razões da ordem de 5:1. A ocorrência de magnetita como ünico mineral do grupo é relativamente rara, e quando isso acontece ela parti cipa apenas como um constituinte menor da rocha.

Em geral, esses minerais não apresentam häbitos distin tos em função do grupo a que pertencem, mostrando sempre formas granulares, ameböides ou mesmo alongadas. Muito raramente vê-se um cristal subhedral ou euhedral. No entanto, nos anfibolitos intensamente afetados pelo retrometamorfismo, esses minerais exi bem invariavelmente formas irregulares e evidências de intensa transformação mineralögica. Estas acham-se traduzidas na presen ça de titanita, formada às expensas dos opacos, e disposta ao seu redor, ou mesmo penetrando as porçóes mais interiores dos cristais. Em adição à titanita, os opacos encontram-se também associados aos anfibölios, caso, por exemplo, da amostra E-ll, circundando-os, parcialmente envolvidos por eles, ou mesmo dis postos ao longo de seus planos de clivagem.

Um programa inicial visando à identificaçäo desses mine rais foi levado a efeito por GIRARDI (1969), quando então resí duos de opacos analisados por meio de difratogramas de raios $\bar{x}$ revelaram a presença de magnetita e ilmenita.

Com o auxilio da microssonda, procurou-se caracterizar 
quimicamente os opacos, nos diferentes grupos de anfibolitos, bem como estabelecer a sua abundancia relativa. 0s resultados obtidos para as diferentes amostras de cada grupo constam das Tabelas XIV, XV e XVI, enquanto que os valores médios acham-se reunidos na Tabela $X V \mid l$.

TABELA XIV

Composição química parcial de ilmenita do andesina-labradorita anfibolito $A-184$

$\begin{array}{cr}\text { TiO }_{2} & 49,6 \\ \mathrm{Al}_{2} \mathrm{O}_{3} & 0,01 \\ \mathrm{FeO}^{*} & 41,8 \\ \text { Total } & 91,41 \\ \text { *Feo calculado como FeO }\end{array}$

Discussão dos Resultados - 0 exame das tabelas permite con cluir que os resultados, dentro de cada grupo litológico, mos tram pequenas variações para os elementos principais $\mathrm{Ti}$ e Fe, como evidenciado pelos totais das análises químicas, ora prōxi mos de $100 \%$, ora bem distantes. Os dados possibilitam igua mente concluir que a magnetita presente nessas rochas possui um teor extremamente baixo em titânio. Quando confrontadas as médias constantes da Tabela XVII, particularmente no tocante à ilmenita, observa-se que as diferenças encontradas são muito pe quenas, conquanto existentes como se depreende dos valores da razão $\mathrm{Fe} / \mathrm{Ti}$. Jä no caso da magnetita, a diferença torna-se muito acentuada, uma vez incluído no cālculo da mëdia o valor referente à amostra $A-370$ (Tabela XV), um oligocläsio-andesina anfibolito trazendo magnetita com $5,34 \%$ de $\mathrm{Ti}_{2}$ em sua composi ção. Esta anālise ē responsāvel pela razão Fe/Ti mais baixa desse grupo relativamente aos albita anfibolitos. 


\section{TABELA XV}

Composição química parcial de ilmenita e magnetita dos oligocläsio-andesina anfibolitos da região de Morretes - Antonina

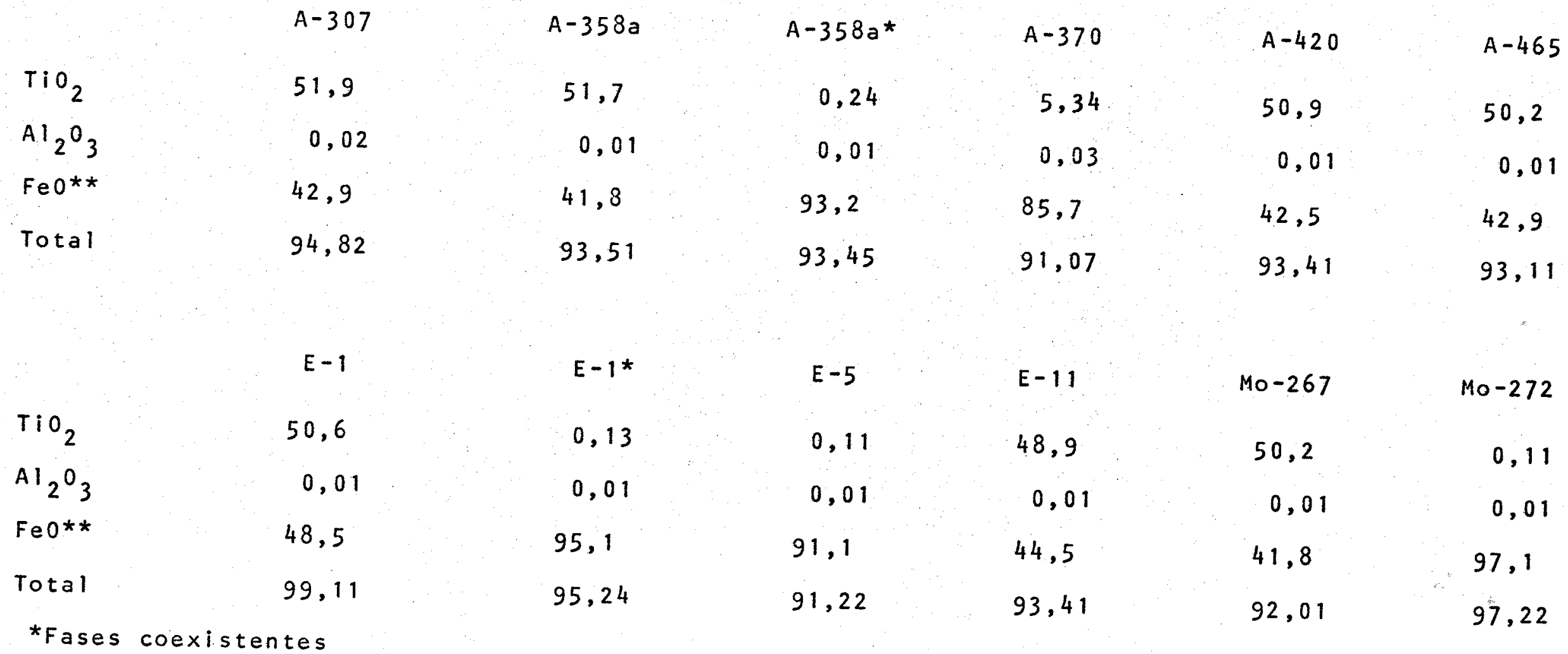

**Fe calculado como FeO 
TABELA XVI

Composição química parcial de ilmenita e magnetita dos albita anfibolitos da região de Morretes - Antonina

\begin{tabular}{|c|c|c|c|c|c|c|c|c|}
\hline & $A-25 a$ & $A-25 a *$ & $A-37 a$ & $A-37 a^{*}$ & $A-207$ & $A-207^{\star}$ & $A-306 a$ & $A-306 b$ \\
\hline $\mathrm{TiO}_{2}$ & 50,0 & 0,13 & 51,1 & 0,12 & 55,0 & 0,01 & 50,0 & 51,1 \\
\hline $\mathrm{Al}_{2} \mathrm{O}_{3}$ & 0,01 & 0,00 & 0,01 & 0,01 & 0,02 & 0,01 & 0,02 & 0,01 \\
\hline $\mathrm{FeO} * *$ & 43,7 & 94,1 & 42,7 & 93,1 & 45,5 & 97,5 & 44,0 & 45,9 \\
\hline Total & 93,71 & 94,23 & 93,81 & 93,23 & 100,52 & 97,52 & 94,04 & 97,01 \\
\hline
\end{tabular}

$\begin{array}{cccccccc} & A-337 & A-478 a & A-481 & E-19 & \text { Mo-249 } & \text { Mo-250a } & \text { Mo-250a* } \\ \mathrm{TiO}_{2} & 49,5 & 0,12 & 49,7 & 50,9 & 49,9 & 0,09 \\ \mathrm{Al}_{2} \mathrm{O}_{3} & 0,02 & 0,01 & 0,01 & 0,01 & 0,01 & 0,01 \\ \mathrm{FeO**} & 42,2 & 91,9 & 46,2 & 41,6 & 43,0 & 45,3 \\ \text { Total } & 91,72 & 92,03 & 95,91 & 92,51 & 92,91 & 94,31\end{array}$

${ }^{*}$ Fases coexistentes

**Fe calculado como FeO 
TABELA XVII Composição química mëdia das fases coexistentes de opacos nos
diferentes grupos de anfibolitos de Morretes - Antonina

\section{Andesina - labradorita anfibolitos}

IImenita

$\begin{array}{lr}\mathrm{TiO}_{2} & 49,6 \\ \mathrm{Al}_{2} \mathrm{O}_{3} & 0,01 \\ \mathrm{FeO} & 41,8 \\ \text { Total } & 91,41 \\ \mathrm{Fe} / \mathrm{Ti} & 1,09\end{array}$

0ligocläsio-andesina anfibolitos

$\begin{array}{lcc} & \text { Ilmenita } & \text { Magnetita } \\ \mathrm{TiO}_{2} & 50,6 & 1,19 \\ \mathrm{Al}_{2}{ }^{3} & 0,01 & 0,01 \\ \mathrm{FeO}^{3} & 43,6 & 92,4 \\ \text { Total } & 94,21 & 93,60 \\ \mathrm{Fe} / \mathrm{Ti} & 1,12 & 101,1\end{array}$

Albita anfibolitos

IImenita Magnetita

$\begin{array}{lcc}\mathrm{TiO}_{2} & 50,6 & 0,10 \\ \mathrm{Al}_{2} \mathrm{O}_{3} & 0,01 & 0,01 \\ \mathrm{FeO} & 44,0 & 94,5 \\ \mathrm{Total} & 94,61 & 94,61 \\ \mathrm{Fe} / \mathrm{Ti} & 1,13 & 122,4\end{array}$




\section{A QUIMICA MINERAL E 0 GRADIENTE METAMÓRFICO}

Feldspatos

TILLEY (1924), estudando os efeitos do metamorfismo de contato em rochas dos Highlands, Escöcia, observou que o teor da molécula de anortita dos plagiocläsios varia diretamente com a intensidade do gradiente metamörfico. VOGT (1927, citação em MIYASHIRO, 1968) determinou a variação composicional dos plagioclāsios em uma sērie de gabros metamorfoseados na ārea de Sulitelma, Suēcia. Na oportunidade, pode observar um contínuo empobrecimento da molëcula de anortita desses minerais com o decrēscimo da temperatura de formação, sendo que nas regiões de baixa temperatura, correspondente á fäcies dos xistos verdes, o plagioclāsio estāvel é a albita. A exemplo daqueles autores, PHILLIPS (1930), WISEMAN (1934), WAARD (1959), GOMES (1962), ENGEL e ENGEL (1962a), ENGEL et al. (1964), GOMES et al. (1964), BINNS (1964), MIYASHIRO (1968), GOMES (1971, 1972) e WENK et al. (1974) vêm investigando o comportamento químico de plagioclā sios em rochas metamōrficas, de regiões completamente distin tas, submetidas a condições variāveis de metamorfismo, tendo in variavelmente chegado a resultados idênticos.

Fato que particularmente chamou a atenção dos diversos petrólogos foi a mudança composicional dos plagioclásios duran te todo o campo de variação do gradiente metamörfico, sendo que a cada intervalo de temperatura de cristalização, parece corres ponder um membro da sërie com um teor de anortita definido é correspondente àquele intervalo. Isso fez com que MIYASHIRo (1968) passasse a utilizar o teor de anortita dos plagioclásios como indice do gradiente metamörfico.

No Brasil, coube a GOMES (1962) a iniciativa pioneira de correlacionar a composição dos plagioclāsios, determinada op ticamente, e o gradiente metamörfico, em anfibolitos do Jaraguá, 
São Paulo. Um estudo mais minucioso por parte do mesmo (GOMES, 197i, 1972), utilizando dessa vez dados químicos, autor tiu concluir que esses minerais, permi ratura provocada esses minerais, em virtude da elevação de tempe ratura provocada por uma intrusão granitica, sofreram modifica ções diversas, aumento do tamanho dos grãos, maior abundância e enriquecimento em cālcio, etc.

No tocante aos anfibolitos de Morretes-Antonina, a riação da composição dos plagiocläsios, embora processada em sen tido oposto, guarda inteira concordancia com os resultados obtidos por GOMES (1971, 1972). As anālises químicas, reunidas nas Figuras 5 e 6 , evidenciam claramente que os plagioclásios acham- se situados em très campos distintos, sendo que, nos dois pri meiros, os pontos se distribuem maciçamente na região compreendi da entre $A_{0-5}$ e $A_{20-37}$, embora em ambos os casos os 1 imites su periores possam ser estendidos até $A n_{9}$ e $A_{40}$, se consideradas as regiões de menor incidência de plagiocläsios. A separação desses dois campos é devida à existência dos "peristerite" defi nidos previamente. O terceiro acha-se compreendido pelo interva 10 An $_{45-75}$, definido, no entanto, a partir de dados referentes apenas a duas amostras.

Anälises químicas dos anfibolitos representantes de ca da grupo (GIRARDI, 1969, 1971) demonstram nitidamente que as va riações em CaO dessas rochas não são muito significativas. Mesmo em se tratando dos andesina-labradorita anfibolitos, portadores de plagioclásios mais cálcicos, è possível observar-se que os seus valores em $\mathrm{CaO}$ estão em geral dentro do campo de variação desse óxido para os demais grupos. Esse fato parece indicativo de que a composição da rocha não teve qualquer influência sobre a natureza dos plagioclásios, com esta dependendo tão somente do gradiente metamörfico.

os resultados evidenciam que, devido à distribuição geo gräfica irregular dos corpos anfibolíticos, como visíiel no mapa de localização das amostras (Figura 1), a ação do retrometamor fismo se fez sentir em intensidade variävel. Nos albita anfibo litos, os efeitos foram mais intensos, a julgar-se pela escassez 
de remanescentes cálcicos, atestando o caráter polimetamórfico dessas rochas. Esse estägio final se deu em condições de baixa temperatura. A intensidade do fenômeno sobre os oligocläsios-andesina anfibolitos varia de local para local, tornando-se mais acentuada nos corpos portadores de maior concentração de albita coexistente com um plagiocläsio mais cālcico. De qual quer maneira, os plagioclásios mais cälcicos desse agrupamento se formaram em condições inferiores de temperatura relativamen te aos minerais do grupo dos andesina-labradorita anfibolitos.

\section{Anfibólios}

As pesquisas realizadas nas ültimas dēcadas demonstra ram ser possível estabelecer relações entre o quimismo de miné rais coexistentes em rochas metamörficas e as condições de crís talização. Devido a sua estabilidade dentro de amplos limites de metamorfismo e a sua grande variabilidade de composição, os anfibölios vêm merecendo enorme atenção por parte dos pesquisa dores.

WISEMAN (1934) foi o primeiro autor a correlacionar a composição quimica das hornblendas e o gradiente metamörfico,em seus estudos sobre epidioritos da região central e sudoeste dos Highlands da Escócia. A exemplo desse autor, muitos outros pes quisadores se preocuparam com o problema, estudando äreas preli minarmente conhecidas quanto ao gradiente metamörfico, para en tão poder extrair conclusões sobre o comportamento químico dos diversos elementos presentes nesses minerais. Dentre esses au tores, mencione-se HARRY (1950), SHIDO (1958), SHIDO e MIVASHIRO (1959), ENGEL et al. (1961), ENGEL e ENGEL (1962b), BINNS (1965), LEAKE (1965), GOMES (1971), GOMES et al. (1972) e WENK et $a l$. (1974).

A presença de actinolita em rochas metamörficas de bai xo grau, e hornblenda nas de grau elevado, levou HARRY (1950) 
a sugerir que o aumento de temperatura se faz acompanhar pela substituição de Si por Al, na estrutura desses minerais. Por outrolado, SHIDO (1958) e SHIDO e MIYASHIRO (1959) sugeriram que $\mathrm{Na}+\mathrm{K}$ tendem a aumentar com a elevação do gradiente metamōr fico. LEAKE (1965), num trabalho de revisão a partir de dados coligidos da literatura, verificou que as sugestões daqueles au tores são vālidas tão somente para rochas de grau metamórfico baixo, quando ocorrem transformações de actinolita para hornblen da; nos anfibölios formados em condições de metamorfismo mais enērgico, onde tem lugar apenas a transformação de uma hornblen da em outra, aquela correlação com o gradiente metamōrfico tor na-se mais dificil de ser precisada. Ainda nesse trabalho, LEAKE (1965) concluiu que a composição da hornblenda originada em con dições de metamorfismo mais elevado, dentro de amplos limites de pressão e temperatura, ē controlada principalmente pela composi ção da rocha ou do magma. Como exemplo, o referido autor cita a presença de actinolita e tremolita em rochas da fácies anfibo lito, de composição apropriada, como mármores impuros ou rochas ultramäficas metamorfoseadas. Apesar da sua dependência relat vamente à composição da rocha, as hornblendas podem ser adequadá mente investigadas, uma vez conhecida a composição química da rocha, permitindo, assim, com as devidas correções, estabelecer- se mudanças químicas ocorridas como reflexos de variações do gradiente metamörfico. WENKE et al. (1974), em seu estudo sobre anfibölios calcíferos e anfibolitos da região de Lepontine, Al pes Centrais, chegaram a conclusões similares às de LEAKE (1965). Nesse trabalho, verificou-se que, ao lado de uma variação compo sicional sistemática dos plagiocläsios em direção às zonas de baixo grau metamórfico, as hornblendas apresentavam uma composi ção limitada, e que raramente estavam associadas às actinolitas. observaram, também, que o teor de magnësio nas hornblendas, assim como nas rochas anfibolíticas, aumenta com a intensidade do me tamorfismo, e que hă uma nitida interdependência entre os valo res da razão Mg/Fe para hornblendas, biotitas e rocha hospedeira. Segundo ainda esses autores, os teores de $\mathrm{Fe}_{2} \mathrm{O}_{3}, \mathrm{Na}_{2} \mathrm{O}$ e $\mathrm{H}_{2} \mathrm{O}$ nos anfibölios tendem a decrescer com a elevação do gradiente. 
No Brasil, pouco se tem investigado a respeito do com portamento químico de anfibölios em anfibolitos. Coube a GOMES (1971) e, posteriormente, GOMES et al. (1972), a iniciativa de correlacionar o quimismo de anfibólios com o gradiente metamórfí co, no já referido estudo do corpo anfibolítico do Jaraguā, são Paulo. Esse estudo se revestiu de grande importancia, visto que, pelo fato desses anfibolitos constituirem uma ocorrencia ünica, foi possivel executar-se um estudo sistemätico do quimismo des ses minerais ao longo de todo o corpo, atē a sua zona de contato com extensa massa granitica. Na oportunidade, esses autores ve rificaram que os anfibölios exibiam variações sistemáticas de com posição ao longo do corpo; nas regiões próximas ao contato, es ses minerais apresentavam-se mais enriquecidos em ferro, ao lado de empobrecidos em magnésio. Essas diferenças foram interpreta das como devidas a modificações das condições metamörficas provo cadas pela intrusão granítica. Ainda, segundo esses autores, o aumento progressivo do gradiente se fez acompanhar por um conco mitante enriquecimento em $A I^{i v}, A I^{V I}$ e $T i$ nesses minerais,enquan to que os älcalis permaneceram mais ou menos constantes. A exem plo dessa ocorrência, deve ser lembrado que os anfibolitos de Morretes-Antonina, a despeito de sua situação geolögica distinta, podem ser comparäveis entre si, uma vez que a ocupação química das posições estruturais dos anfibólios depende antes que tudo das condições metamōrficas superimpostas.

\section{AZuminio - Como referido, WISEMAN (1934) correla} cionou a composição química das hornblendas com o grau de meta morfismo da rocha hospedeira, de natureza bäsica, em seu trabalho sobre a região dos Highlands da Escócia. Segundo esse autor, Si ë substituído por Al durante a elevação do gradiente metamórf co da ärea. THOMPSON (1947), procurando correlacionar Al e a po sição estrutural dos silicatos, concluiu que Al tende a exibir coordenação tetraēdrica nas rochas de alta temperatura, e octaé drica nas de baixa. Ainda no mesmo trabalho, o autor acabou tam bém por concluir que o efeito da pressão hidrostática. $\ddot{\text { menos }}$ evidente. BINNS (1965), realizando estudos em rochas metabás 
cas do Willyama Complex, Nova Gales do Sul, concluiu que, do pon to de vista das reações minerais, um dos principais efeitos cau sados pelo aumento do gradiente metamörfico parece residir na forma com que o $\mathrm{Al}$, substituindo o Si na posição estrutural $Z$, $\bar{e}$ balanceado. Por outro lado, em contradição ao exposto, ENGEL e ENGEL (1962), em seu estudo sobre hornblendas formadas em condi ções de metamorfismo progressivo, na região de Andirondack Mountains, Nova York, EUA, verificaram que as variações de $s i$ e Al são pouco significativas.

Correlações de $A l^{V I}$ com a pressão de cristalização, jä haviam sido sugeridas por WICKMAN (1943, citação em LEAKE, 1965). A partir de dados coligidos da literatura, LEAKE (1965)verificou que anfibólios metamórficos tendem a trazer em sua estrutura conteúdo mais al to em $A l^{V}$ relativamente aos anfibólios igneos, interpretando essa observação como um reflexo das temperaturas mais altas de cristalização das rochas igneas e de diferenças de pressão durante a cristalização, visto que os anfibölios de bai xo grau contêm sabidamente pequena quantidade de Alvi. Em adição a esses dados, verificou, ainda, que anfibólios associados a cia nita, jadeíta e glaucofânio, minerais indicadores de alta pres são, continham um māximo possível de $A l^{v i}$ em relação a $\mathrm{Si}$. Ape sar do teor de $A l^{v i}$ estar condicionado à pressão, LEAKE (1965) manifestou opinião de que a quantidade desse elemento em anfibö lios calcíferos não é proporcional à sua atuação durante o pro cesso de cristalização, uma vez que considera a composição da rocha não menos importante. Isso porque muitos anfibólios de al to teor em $A l^{v i}$ provém de rochas aluminosas, disso resultando ser - seu conteúdo em $A l^{v i}$ devido à combinação da composição da ro cha e alta pressão. Numa situação inversa, um anfibölio pobre em $A I^{V I}$, mas que comprovadamente se cristalizou em condições de alta pressão, deve o seu baixo teor em Al a escassez desse ele mento na rocha hospedeira. Ainda se referindo ao mesmo autor, uma observação importante que deve ser feita diz respeito às di ficuldades do uso desse parâmetro como medida de mudanças de pressão em regiões metamorfoseadas, uma vez que a composição da rocha e do plagioclásio associado, o qual é relacionado à tempe 
ratura, tambēm influencia a quantidade de Al octaēdrico.

Nos anfibolitos do Jaraguā, GOMES (1971) e GOMES et al. (1972) verificaram que os anfibólios situados prōximos à região de contato com o granito são mais ricos em Al'v e Alvi, o que permitiu concluir que os mesmos teriam sido submetidos a condi ções de pressão mais intensa ou, alternadamente, de temperatura mais elevada.

A vista do exposto, verifica-se que o comportamento do alumínio é um tanto controvertido, com duas linhas de pensamento sendo seguidas: uma considerando a temperatura como o fator bàs co de controle do teor de Al'v nos anfibólios, enquanto que ou tra assumindo que o $A l^{v i}$ estaria condicionado à pressão, a de peito da sua dependência da composição da rocha.

A Figura 15 mostra a projeção de $A l^{\prime V}$ e $A f^{v i}$ para os an fibölios de Morretes-Antonina. Nesse gräfico, são perfeitamente visiveis dois campos distintos, um deles reunindo os anfibólios de alto e médio grau metamörfico (respectivamente, andesina-labra dorita e oligocläsio-andesina anfibolitos), enquanto que o outro contendo os anfibölios de baixo grau (albita anfibolitos). Alguns pontos correspondentes aos oligocläsio-andesina anfibolitos acham- se também contidos no segundo campo. Esses pontos correspondem à fase actinolítica coexistente com as hornblendas dos anfiboli tos estabilizados em gradiente intermediärio.

A anälise da Figura 15 permite que se tire conclusões a respeito de alguns pontos. Em ambos os campos, pode-se notar a influência marcante da pressão, conquanto a temperatura pareça ter sido fator mais importante. Considerando apenas o campo correspondente aos anfibolitos de grau mais elevado, verifica-se que a maioria dos pontos acha-se concentrado dentro de uma es treita faixa, limitada entre 1,4 e 1,65 de $A l^{\prime}$, enquanto nas ordenadas observa-se uma variação significativa de $A)^{v i} \quad(0,32$ a 0,82 ), evidenciando, assim,que, ao lado das condições de tempera tura elevada, a pressão assumiu um papel bastante importante. Da mesma forma, no grupo dos albita anfibolitos, representando as rochas formadas em baixas temperaturas, pode-se notar que o Al'v 
é menos variävel relativamente a $\mathrm{Al}^{\mathrm{vi}}$; por exemplo, se tomado o ponto correspondente a 0,26 , ou então aquele em torno de 0,5 , vê-se nitidamente que para um valor aproximadamente constante de $A l^{i v}$, há uma variação bastante significativa nas ordenadas, ou seja, na concentração de $A I^{V I}$, sugerindo, assim, uma certa in fluência da pressão. Pode-se, ainda, extrair do gräfico a con clusão de que algumas das rochas afetadas pelo retrometamorfismo se formaram em condições de pressão muito baixa, como indicado pe los teores extremamente baixos em Alvi.

\section{Alcalis - Estudos por SHIDÕ e MIYASHIRO: (1959) em} rochas básicas do plató central de Abukuma, Japão, possibilita ram concluir que o teor de älcalis das hornblendas pode ser cor relacionado com as condições de pressão e temperatura em que se deu a cristalização. Segundo esses autores, o conteūdo em älca lis de hornblendas de uma particular fäcies de metamorfismo au menta com a elevação do gradiente metamörfico. BINNS (1965), com base em investigações realizadas em rochas do Willyama Complex, chegou a conclusões semelhantes; por outro lado LEAKE (1965), co mo mencionado anteriormente, acredita que o uso do teor de älca lis como medida da intensidade de processos metamōrficos è väli do apenas para as rochas de baixo grau.

Em realidade, os vários trabalhos no gênero têm demons trado que o comportamento dos älcalis nos anfibólios em rochas submetidas à metamorfismo variāvel nem sempre é uniforme. Assim, enquanto ENGEL e ENGEL (1962b) conseguiram agrupar anfibolitos formados em condições metamörficas diversas em dois campos per feitamente definidos, equivalentes às regiões de Emeryville e Colton, a partir do gräfico relacionando $\mathrm{Ca}$ e $(\mathrm{Na}+\mathrm{K})$ em anfi bölios, GOMES (1971) e GOMES et al. (1972) não observaram varia ções significativas nos teores desses elementos junto aos anfibö lios das rochas do Jaraguá.

Os dados reunindo $\mathrm{Ca}$ e $(\mathrm{Na}+\mathrm{K})$ para os anfibólios de Morretes-Antonina estão projetados na Figura 16. A distribuição dos pontos guarda concordāncia com a obtida por ENGEL e ENGEL 
(1962b), uma vez que é possivel delimitar dois campos dis tintos. Oprimeiro representa os anfibolitos de baixo grau, com um teor em älcalis variando entre 0,05 e 0,2 ; a única execção re side na presença de um anfibólio de composição actinolítica (grau baixo de metamorfismol coexistindo com minerais de grau médio. 0 segundo campo, bem afastado do anterior, contēm apenas pontos correspondentes aos anfibölios formados em condições de metamor fismo de grau mēdio e alto, com um teor em álcalis variävel de 0,45 a 0,63 . Entre os dois campos são encontrados pontos relati vos aos anfibólios zonados e às fases coexistentes dos oligoclä sio-andesina anfibolitos. Assim, a partir do diagrama da Figura 16, pode-se concluir que os anfibólios dos anfibolitos de Morre tes-Antonina formam dois agrupamentos distintos, um mais rico em àlcalis, com os minerais tendo se originado em condições de meta morfismo de grau mēdio a alto (oligocläsio-andesina e andesina- labradorita anfibolitos), e outro mais pobre, correspondendo aos minerais de baixo grau (albita anfibolitos).

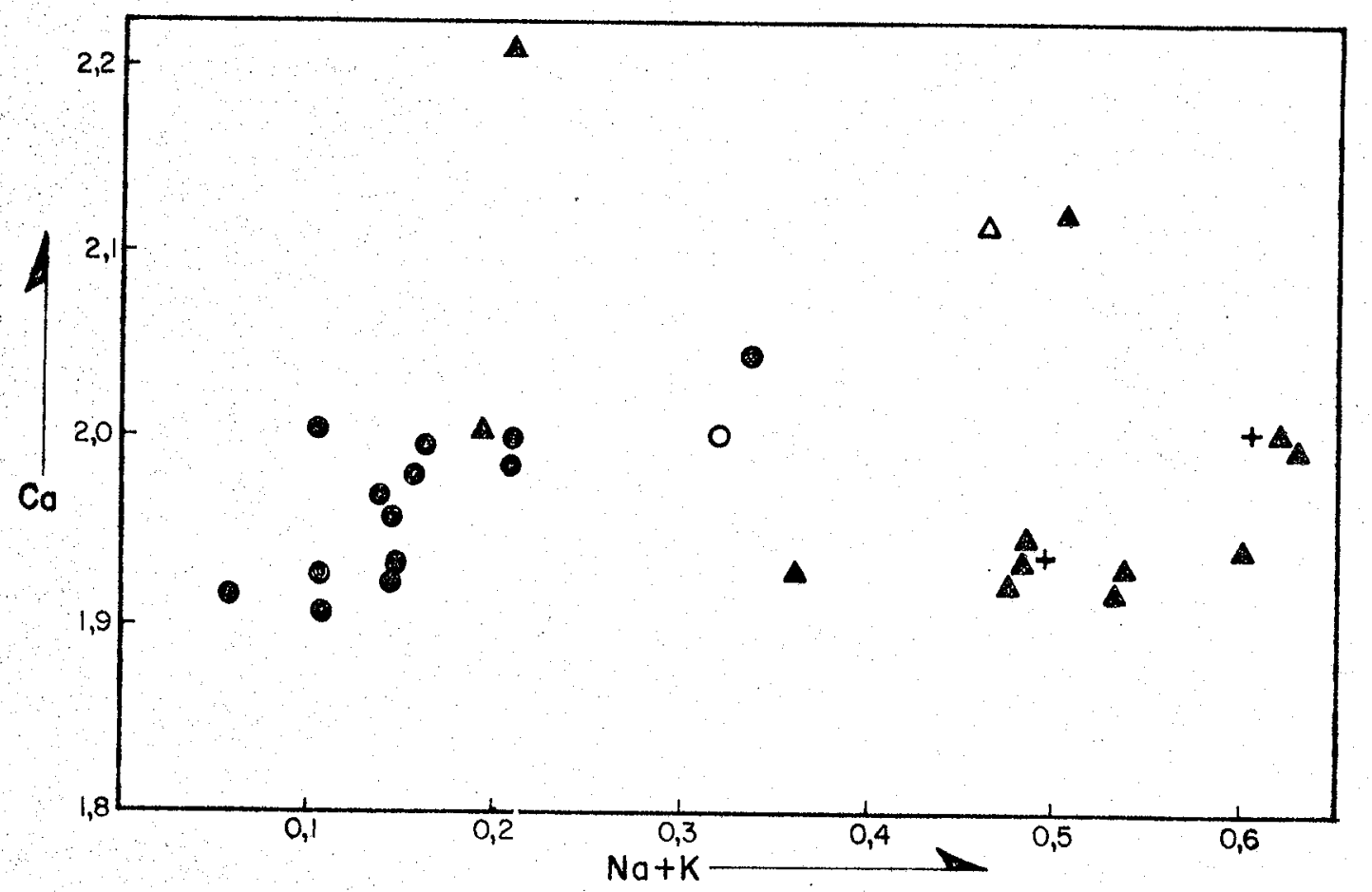

Figura 16 - Gräfico reunindo os valores de $\mathrm{Ca}$ e (Na+K) para os anfibólios de Morretes-Antonina. 
Titânio - DEER (1938) nótou,pëla primeìra vez,a interde pendência entre as propriedades físicas e a composição química de anfibölios. Segundo esse autor, a concentração de titânio nas hornblendas guarda relação direta com a cor marrom desses minerais. Uma vez que hornblendas de cor marrom são sabidamente estáveis apenas em condição de metamorfismo de alto grau, vā rios autores viram no fato a possibilidade de se estabelecer um novo parâmetro para medidas de variação do gradiente metamörfico.

ENGEL e ENGEL (1962b), em seu estudo sobre as rochas da região de Adirondack Mountains, observaram que a concentra ção de $\mathrm{TiO}_{2}$ nas hornblendas aumenta com o grau de metamorfismo; por outro lado, BINNS (1965) concluiu, junto às rochas básicas metamorfoseadas do Willyama complex, que um dos principais efe tos causados pela elevação do grau de metamorfismo nas hornblen das desses anfibolitos consiste do aumento do seu teor em titâa nio. Conclusão idêntica foi obtida por GOMES (1971) e GOMES et az. (1972) junto às hornblendas do corpo anfibolítico do Jara guä. LEAKE (1965), em seu trabalho de revisão sobre anfibólios calciferos e subcalcíferos, observou que a substituição de $\mathrm{Ti}$ na estrutura de minerais silicäticos é controlada principalmente pela temperatura. Segundo ainda esse autor, a presença de ilmenita em rochas anfibolíticas indica que os seus anfíbölios estão saturados em óxido de titânio.

0 exame da Tabela XII, reunindo a composição mēdia dos anfibólios dos anfibolitos de Morretes-Antonina, evidencia cla ramente que o teor de $\mathrm{TiO}_{2}$ desses minerais varia de forma cres cente, quando passando dos albita anfibolitos até os andesina- labradorita anfibolitos. A projeção dos pontos corresponden tes aos valores de Si e Ti (Figura 17), extraídos das Tabelas VII, IX e XI, demonstra que essas variäveis guardam relação in versa, com os anfibolitos de baixo grau contendo alto teor em Si e baixo em Ti; neste grupo, a variação do teor de Ti é muito pequena. Por outro lado, os anfibolitos de grau médio a alto, ao lado do teor mais alto em $\mathrm{Ti}$ e muito mais baixo em $\mathrm{Si}$, apre sentam, igualmente, uma grande variação no conteúdo em Ti $(0,0 \overline{4}$ 


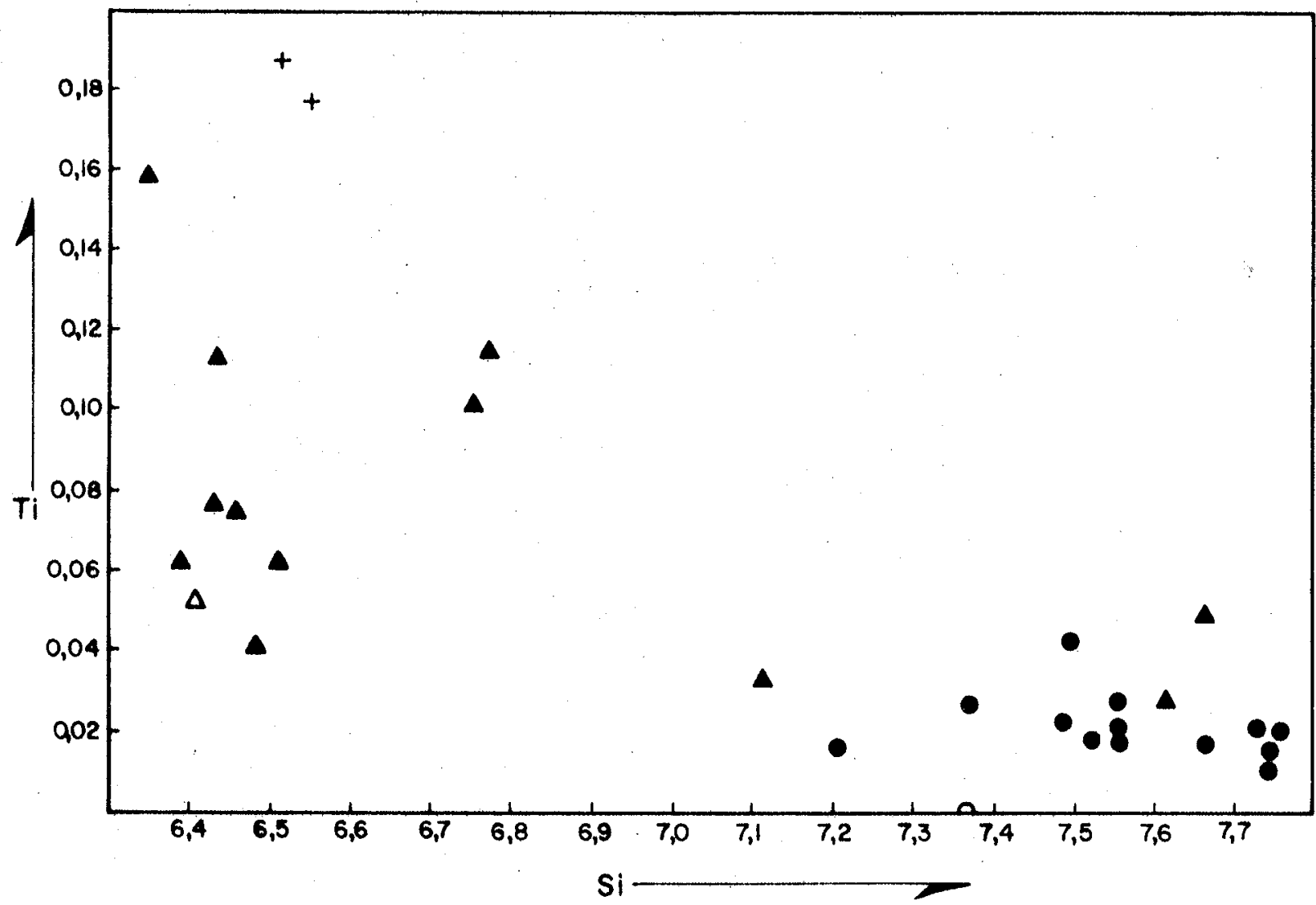
$\begin{aligned} \text { Figura } 17 \text { - Gráfico reunindo os valores de Ti e Si para os anf } & \text { bólios de Morretes-Antonina. }\end{aligned}$

a 0,19$)$. A exemplo do observado nas figuras 15 e 16 , verifica-se, tambēm, a existência de alguns pontos dispersos entre os dois campos, correspondendo aos anfibölios zonados e às fases coexistentes dos oligocläsio-andesina anfibolitos.

Os dados corroboram as conclusões obtidas anteriormen te quanto ao comportamento do alumínio e dos álcalis nesses mi nerais, ou seja, os anfibólios formados em condiçós metamórfí cas mais intensas (oligocläsio-andesina e andesina-labradorita anfibolitos) mostram-se mais enriquecidos em Al ( $I^{\mid \vee}$ e $A I^{v i}$ ), $(\mathrm{Na}+\mathrm{K})$ e Ti, relativamente àqueles de baixo grau (albita anfibo 1 itos). 
Opacos

A literatura especializada tem demonstrado que não há quase dados químicos sobre o comportamento de minerais opacos em rochas anfibolíticas polimetamórficas, cabendo a HOWIE (1955), ENGEL et a . (1964) e GOMES (1971, 1973) a autoria de poucos trabalhos existentes.

ENGEL et al. (1964) observaram que ilmenitas presentes em anfibolitos da região dos Adirondack Mountains, Nova York, va riam em quantidade com o gradiente metamörfico, bem como que ti tanita, formada a partir da alteração daqueles minerais, tende a desaparecer em condições de metamorfismo mais enērgico. Por outro lado, anālises químicas desses minerais revelaram uma pe quena variação dos teores dos seus componentes químicos princi pais com o gradiente; essa variação parece indicátiva de que nesses minerais $\mathrm{Ti}$ aumenta levemente com a elevação do metamor fismo, enquanto que Fe se comporta de forma antagónica. Em seu estudo sobre o quimismo de ilmenitas dos anfibolitos do Jaraguá, GOMES (1971, 1973) verificou que Ti mantēm-se mais ou menos cons tante, enquanto que Fe decresce ligeiramente com o aumento do gradiente.

Como visto nas Tabelas XV a XVII, as ilmenitas das ro chas de Morretes-Antonina apresentam diferenças químicas muito pequenas, conquanto não se possa negar que a quantidade de Feo diminui muito discretamente junto aos andesina-labradorita anfi bolitos; por outro lado,o teor de $\mathrm{Ti}_{2}$ comporta-se de maneira razoavelmente uniforme junto aos três grupos litológicos.

Se confrontados os valores da razão Ti/Fe nas rochas acima, nota-se uma leve, porëm significativa, variação passan do-se de 1,13, nos andesina-labradorita anfibolitos, a 1,12 nos oligoclásio-andesina anfibolitos, e, finalmente, a 1,09, junto aos albita anfibolitos. Por sua vez, ENGEL et al. (1964) con seguiram valores muito similares, 1,09 e 1,11, quando examinan 
do, respectivamente, ilmenitas em anfibolitos de médio e a) to grau de metamorfismo. Para rochas granuliticas da região de Madras, India, HOWIE (1955) obteve um valor de 1,33.

No tocante às magnetitas, por sinal ausentes dos andes na-labradorita anfibolitos, os dados são perfeitamente comparä veis uma vez excluído do cálculo do valor médio a amostra $A-370$ portadora de magnetita titanifera. Incluindo-se esta ültima amos tra, tem-se, então, valores muito distintos para a razão Ti/Fe, 101,1 e 122,4, respectivamente, junto aos oligocläsio-andesina anfibolitos e albita anfibolitos. 
ME TAMORF I SMO

As evidências químicas não deixam quaisquer dūvidas de que os anfibolitos da região de Morretes-Antonina são polimeta mórficos, com a ültima fase de metamorfismo, que por sinal não afetou todas as rochas da área, sendo responsävel pela estabili zação dos minerais em condições de baixa temperatura.

A Figura l mostra que um segundo evento de carätér ni tidamente regressivo atuou de maneira distinta na região, estan do as rochas mais atingidas pelo processo confinadas a uma fai xa (1, no mapa da Figura 1), orientada para NE e situada a les te de São João da Graciosa, relativamente estreita, onde anfibó litos albiticos ocorrem associados a clorita xistos e xistosmag nesianos. Esse ciclo metamōrfico parece estar relacionado à in trusão de maciços graníticos pōs-tectônicos, responsāveis pelo desenvolvimento de fraturas que se fizeram acompanhar da defor mação e cizalhamento das encaixantes regionais. A intensa téc tônica de borda desses corpos propiciou condições favoräveis à circulação de soluções, provocando reações químicas e levando à formação de assemblēias mineralögicas estáveis em metamorfismo de baixo grau. Por outro lado, rochas aflorando nas zonas 11 do mapa foram pouco atingidas pela diaftorese ou mantiveram-se mesmo completamente inalteradas.

Como previamente referido, as rochas das faixas 11 ( $F$ gura 1) foram submetidas a metamorfismo regional de mëdio a a to grau, em condições compatíveis com a fäcies anfibolito de TURNER (1968). Aqui se incluem, segundo GIRARDI (1971), os mig matitos homogêneos e heterogêneos, portadores de oligoclāsio e andesina, gonditos, oligoclāsio-andesina anfibolitos e andesina- labradorita anfibolitos. Superposto a esse evento, teve lugar um segundo, de carāter mais localizado, com as paragêneses mine rais apontando condições condizentes com a fäcies dos xistos verdes de TURNER (1968). Enquadram-se aqui os gnaisses e anfi bolitos albiticos, xistos magnesianos, clorita xistos e quartzi 
tos com magnetita (GIRARDI, 1971).

As informações coligidas neste estudo estão a indicar que as rochas mais afetadas pelo evento retrometamórfico, os a 1 bita anfibolitos, possuem características químicas muito espe ciais, como indicado pela natureza sōdica do seu plagioclāsio e composição mais actinolítica do anfibölio. Feições adicionais consistem da presença nessas rochas de outros minerais resultan tes de mudanças mineralógicas de baixo grau, como epídoto (forma do a partir da transformação de um plagiocläsio mais cálcico em albita + epídoto), clorita e titanita. Por outro lado, evidên cias quimicas e texturais apontam no sentido de uma transforma ção progressiva dos andesina-labradorita anfibolitos em direção aos albita anfibolitos, como resultado das variações no gradien te metamōrfico regional apontadas atrás. Essas evidências acham- se traduzidas sobretudo na composição extremamente variāvel dos plagioclásios, estendendo-se de $A n_{0} a A_{75}$, assim como na presen ça de estrutura zonada em certos cristais de anfibólio (por exem plo, amostra A-478a), com as partes centrais dos cristais guar dando uma composição mais hornblêndica.

Em termos de química mineral, a transformação de horn blenda, fase estävel em condições metamörficas de médio a alto grau, em actinolita, fase de baixo grau, se fez acompanhar do aumento dos teores de $\mathrm{SiO}_{2}$ e Mgo, ao lado de uma concomitante di minuição dos conteüdos de $\mathrm{TiO}_{2}, \mathrm{Al}_{2} \mathrm{O}_{3}, \mathrm{FeO}, \mathrm{Na}_{2} \mathrm{O}$ e $\mathrm{K}_{2} \mathrm{O}$. Como exaustivamente discutido no capitulo anterior, os teores de $\mathrm{TiO}_{2}$, $\mathrm{Al}_{2} \mathrm{O}_{3}$ e $\left(\mathrm{Na}_{2} \mathrm{O}+\mathrm{K}_{2} \mathrm{O}\right)$ nos anfibölios variam diretamente com a ele vação do gradiente metamörfico. Portanto, as variações encon tradas guardam total concordancia com o observado em rochas anfi boliticas de outras partes do globo. Se analisados os valores médios para as modas dos três agrupamentos litológicos (Tabela $X V|1|$ ), verifica-se que o evento retrometamórfico acarretou va riações marcantes nas concentrações dos principais constituintes mineralögicos. A diminuição dos teores de hornblenda e plagio cläsio acha-se de certa forma compensada pelo aumento das concen trações de actinolita, epídoto, clorita, biotita e opacos. 
Em adição aos eventos metamörficos referidos, alguns locais, dispersos, da região viram-se ainda afetados por um pro cesso metassomätico, caracterizado sobretudo pela formação de minerais potássicos. Esse fenômeno, provavelmente relacionado do ponto de vista genético com os maciços graníticos da ärea,al cançou maior expressão junto à amostra E-23, onde teve lugar a formação de grande quantidade de microclínio.

\section{TABELA XVIII}

Valores modais médios para os grupos de anfibolitos da região de Morretes - Antonina

01 igocläsioandesina-labradorita an fibolitos
01 igocläsio-andesina anfibolitos

Albita anfibolitos
Actinolita

Hornblenda

Plagiocläsio

Epídoto

Biotita

Clorita

Quartzo

Titanita

Opacos

Apatita

Zircão

Piroxênio

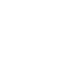

63,6

28,9

8,7

0,4

1,2

0,6
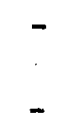

0,9

0,9
31,8

26,8

17,9

8,5

5,6

1,1

2,4

0,1

3,7

0,3

0,5

1,2

0,5

2,8
26,1

11,1

12,2

30,3

8,6

2,5

3,8

1,4

3,8

0,2 
EVOLUÇAOO DOS ANFIBOLITOS

A despeito da inexistência de feições texturais e de da dos quimicos para elementos traços, as relações dos nūmeros de Niggli mg e $\underline{c}$, quando tomadas comparativamente ao "trend" de va riação dos doleritos do Karroo, Africa do Sul (reproduzido em LEAKE, 1964), a distribuição das anälises no diagrama CaO-MgO-Feo de WALKER et $a l .(1960)$, bem como os valores de Tio ${ }_{2}$ e $K_{2} 0$ permi tiram GIRARDI (1969) concluir que os anfibolitos de Morretes-An tonina possuem origem ortometamörfica.

Essas rochas, muito provavelmente antigas intrusivas bäsicas, foram atingidas por um evento metamörfico regional, que atuou por volta de $600 \mathrm{~m}$. a., acarretando-lhes profundas modifica ções texturais e mineralógicas. Numa tentativa de adaptação às novas condições de pressão e temperatura reinantes, os plagioclá sios cálcicos viram-se transformados em termos ligeiramente mais sódicos, enquanto que os piroxênios passaram a anfibölios, estes de natureza hornblēndica, como evidenciado pelo quimismo dos cristais remanescentes. Ao que tudo faz crer, esse metamorfismo regional atuou em toda a àrea de maneira intensa e indistintamen te, alcançando gradiente compatível com a fäcies a julgar-se pela assembléia mineralógica comum aos andesina-la bradorita anfibolitos.

Evidências geocronológicas e de campo estão a indicar que as metamörficas regionais foram invadidas por corpos gran ticos, com a sua intrusão fazendo-se acompanhar de intensa tectô nica de borda. Como resultado, processos de fraturamento e fa Ihamento tiveram lugar, criando, assim, condições altamente favo räveis à percolação dos fluidos emanados desses corpos. As rela ções de contato desses granitos com as encaixantes regionais fo ram investigadas por FUCK (1966), CORDANI e GIRARDI (1967) e, posteriormente, por GIRARDI (1969). Este ültimo autor encontrou junto às rochas anfiboliticas, evidências de metamorfismo de con tato provocado pelas intrusões graníticas. Em värios locais da ärea, essa ação de contato se fez acompanhar de atividades metas 
somáticas levando à formação de minerais potässicos, em especial microclínio. Aplicando a termometria de BARTH (1962) às rochas da ärea, GIRARDI (1969) concluiu que os oligocläsio-andesina gnaisses, e, por extensão, os oligoclásio-andesina e andesina-la bradorita anfibolitos, formaram-se em temperaturas ao redor de 480-520 $\mathrm{C}$, enquanto que os granitos cristalizaram-se em torno de $700-750^{\circ} \mathrm{C}$. Idades Rb-Sr para as rochas graniticas da área confirmam que elas são mais jovens que as metamörficas regio nais, com os valores, incluindo tambēm aqueles obtidos para os ma ciços do Guaraü e Anhangava, situando-se sobre uma isōcrona de referência de $541 \pm 11 \mathrm{~m} . \mathrm{a}$. (CORDANI e KAWASHITA, 1971). Segun do estes autores, essa idade representa o episōdio pōs-tectónico principal associado à fase de dobramentos Ribeira.

Como previamente referido, processos de cisalhamento fa voreceram a migração de soluções hidrotermais, responsāveis pé la transformação química, mineralógica e textural das metamōrfí cas regionais. A ação dessas soluções foi mais efetiva junto às rochas localizadas na faixa l delimitada no mapa geológico.

Junto às variedades anfibolíticas, o processo de alteração, que, foi parcial ou completo, dependendo de värios fatores, os mais importantes a temperatura e a quantidade de fluidos (GIRARDI, 1969), levou à formação de uma assemblēia mineralōgica reunindo principalmente actinolita (produto de transformação da hornblen da), albita, e epídoto (estes dois ültimos minerais formados a partir da decomposição do plagioclásio original mais cālcico) e titanita (derivada da ilmenita). Essas mudanças mineralógicas, ocorridas à baixa temperatura, certamente inferior a $450^{\circ} \mathrm{C}$ em virtude da presença de albita pura,caracterizam a existência na àrea de um segundo evento metamórfico, este de carāter regress vo, com paragêneses condizentes com a fácies dos xistos verdes. A ação desse evento acha-se tambëm evidenciada nas idades K-Ar coligidas por CORDANI e ABRÃO (1974) em anfibölios e plagioclä sios de alguns anfibolitos da ärea. Os dados são muito diversos, particularmente os obtidos em feldspatos, mineral sabidamente co nhecido como incapaz de reter Ar, uma vez a rocha tenha sido sub metida a um evento geológico posterior a sua formação. 


\section{SUMARIO E CONCLUSÕES}

Os anfibolitos de Morretes-Antonina, ocorrendo na forma de pequenos corpos intercalados em rochas migmatíticas regionais, exibem variações mineralógicas marcantes permitindo separä-los, em conformidade com GIRARDI (1969, 1971), em trēs grupos distín tos: andesina-labradorita, oligocläsio-andesina e albita anfibo Iitos.

Os andesina-labradorita anfibolitos contêm plagiocläsio $\left(A n_{40-75}\right)$ e apenas um tipo de anfibölio como minerais dominantes, enquanto que ilmenita $(\mathrm{Fe} / \mathrm{Ti}=1,13)$ é o principal opaco presente. 0 anfibólio possui composição hornblêndica e, comparativa mente aos minerais dos demais grupos, apresenta maior riqueza

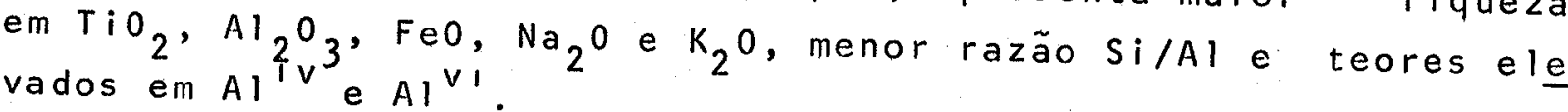

Os oligoclāsio-andesina anfibolitos são mais heterogê neos química e mineralogicamente, aparecendo duas variedades de anfibölio (hornblenda e actinolita), ao lado de um plagiocläsio de composição igualmente variāvel (An 20-50) como principais com ponentes. Como acessórios, ocorrem ilmenita $(\mathrm{Fe} / \mathrm{Ti}=1,12)$ e magnetita, enquanto que epídoto jā se faz presente em proporções significativas. Relativamente aos termos mais hornbléndicos, as actinolitas têm como caracteristicas químicas marcantes o enri quecimento em $\mathrm{SiO}_{2}$ e Mgo, bem como o aumento da razão Si/Al. Esse grupo representa uma etapa de transição, com as fases mine ralögicas coexistentes guardando características quimicas comuns aos minerais dos agrupamentos extremos, andesina-labradorita an fibolitos e albita anfibolitos.

Os albita anfibolitos constituem as rochas mais altera das da região, mostrando invariavelmente uma textura xistosa de caräter marcadamente nematoblästico. Ao lado do plagiocläsio só dico $\left(A_{0-8}\right)$ e da actinolita, epídoto ganha maior importância, chegando mesmo a superar aqueles minerais em algumas amostras. Biotita aparece ocasionalmente em quantidades apreciāveis, o mes mo ocorrendo com a clorita. Actinolita é o anfibölio mais abun 
dante, com hornblenda, menos enriquecida em $\mathrm{TiO}_{2}, \mathrm{Al}_{2} \mathrm{O}_{3}, \mathrm{Na}_{2} \mathrm{O}_{\text {e }}$ $\mathrm{K}_{2} \mathrm{O}$ relativamente às presentes nos grupos anteriores, aparecendo subordinadamente.

Os anfibolitos de Morretes-Antonina, derivados de ant gas intrusivas básicas, foram atingidos pelo evento metamörfico regional, datado de $600 \mathrm{~m}$. a., correspondente ao Ciclo Brasiliano. $\mathrm{Na}$ região, o gradiente metamörfico foi alto, a julgar-se pela pre sença de hornblenda portadora de teores elevados em Ti, Al' e $A l^{V I}$, e de um plagiocläsio rico em cälcio. Tomando-se como refe rência os dados de literatura, as temperaturas mäximas alcança das durante o evento metamórfico foram da ordem de $550-575^{\circ} \mathrm{C}$, com as rochas exibindo parageneses minerais compativeis com a fäcies almandina anfibolitos ou, mais modernamente, anfibolito.

A fase principal do metamorfismo regional foi seguida pela intrusão de maciços graníticos pós-tectônicos, representa dos localmente pelos granitos Graciosa e Marumbi, revelando ida des ao redor de $541 \mathrm{~m} . \mathrm{a}$. Associado à intrusão desses corpos, te ve lugar o cizalhamento e fraturamento das rochas encaixantes re gionais, com o processo atingindo maior intensidade a leste de São João da Graciosa. Soluções hidrotermais emanadas desses ma ciços acarretaram profundas modificações mineralógicas e quími cas das encaixantes, dando lugar à formação de uma assemblēia mineral de baixa temperatura, condizente com a fácie dos xistos verdes, e contendo albita, actinolita, epídoto, clorita, titani ta e biotita como principais constituintes. Como indicado pela presença de albita pura nessas rochas, a temperatura alcançada pelo episódio retrometamōrfico não foi superior a $450^{\circ} \mathrm{C}$. A ocor rência ocasional de anfibölios zonados, com as partes centrais dos cristais apresentando natureza hornblêndica e as bordas com posição actinolítica, confirma que o processo regressivo atuou posteriormente ao evento metamörfico regional, bem como que equi líbrio metamörfico não chegou a ser atingido. Esta ültima con clusão é tambēm indicada pela presença de plagiocläsio mostrando ampla variação de composição, alēm de fases coexistentes quimi camente heterogêneas. 
Evidências de metassomatismo potässico, levando à for mação de microclínio e biotita, foram reconhecidas em amostras de anfibolitos aflorando em diversos pontos da área. Muito pro vavelmente os maciços granitticos da Graciosa e do Marumbi foram as fontes geradoras das soluções responsāveis pelo processo.

Do exposto, conclue-se que os anfibolitos da região de Morretes-Antonina são rochas policíclicas, tendo sido afetadas inicialmente por um episōdio metamórfico de carāter regional, re lacionado ao Ciclo Brasiliano, e, posteriormente, por um meta morfismo regressivo, de caráter localizado e associado à fase in trusiva dos corpos graniticos pös-tectônicos regionais. Numa tentativa de adaptação às novas condições de pressão e temperatu ra reinantes, os anfibolitos sofreram profundas transformações mi neralógicas e químicas, levando à formação de paragêneses muito distintas das anteriores, sem que, no entanto, equilibrio meta mörfico tivesse sido plenamente atingido. 


\section{AGRADECIMENTOS}

Os meihores agradecimentos à Fundação de Amparo à Pes quisa do Estado de São Paulo (Processo 73/0945), ao Conselho Na cional de Desenvolvimento Científico e Tecnológico (Processo 3653/75), e ao Professor Doutor Riad Salamuni, atravēs da Uni versidade Federal do Paraná, pela assistência financeira que possibilitou a concretização deste trabalho.

Aquele que, em todas etapas do trabalho,esteve presen te com sua orientação e dedicação sem jamais medir esforços, o Professor Doutor Celso de Barros Gomes, meu profundo reconheci mento.

Ao Professor Doutor Vicente Antonio Vitörio Girardi por colocar à disposição as amostras de anfibolitos da região es tudada.

Ao Professor Doutor Setembrino Petri, por ter faculta do a utilização dos laboratórios do Departamento de Mineralogia e Petrologia.

Ao Professor Doutor Josē Moacyr Vianna Coutinho, Profes sor Doutor Horstpeter Ulbrich e Professor Pedro Luiz Pretz Sar tori, por sugestões dadas no transcurso do trabalho.

Agradecimentos são tambēm devidos aos seguintes colabo radores: Antonio Carlos Joaquim,do Instituto de Pesquisas Tec nológicas (Seção de Metalografia), por ter auxiliado na metali zação das lâminas de microssonda; Senhorita ltacy Kroehne e Se nhor Pedro Gennari Filho pela elaboração dos desenhos; Senhora Nair de Campos Louzada e Senhor José Ponchirolli, pela datilo grafia do manuscrito; Senhora Melany Thereza lsauk e Senhores Cláudio Hopp e Valdemar Lucas de 0liveira, pela confecção das làminas de microssonda. A equipe da Seção Gräfica, particularmente em nome do Senhor Jaime Alves da Silva. 


\section{BIBLIOGRAFIA}

AB'SABER, A.N. e BIGARELLA, J.J. (1961) Considerações sobre a geomorfogênese da Serra do Mar no Paranā. Bol. Paran. Geogr., 4-5: 1-94.

BARTH, T.F.W. (1962) The feldspar geologic thermometers. Norsk Geol. Tidsskr, Bind 42 , Feldspar Volume, 330.

BENCE, A.E. e ALBEE, A.L. (1968) Empirical correction factors for the electron microanalysis of silicates and oxides. J. Geol., 76: 382-403.

BINNS, R.A. (1964) Zones of Regional Metamorphism in the Willyama Complex, Broken Hill District, New South Wales.J. Geol. Soc. Australia, 11: 283-330.

BINNS, R.A. (1965) The mineralogy of metamorphosed basic rocks from the Willyama Complex, Broken Hill district, New South Wales. Part 1: Hornblendes. Min.Mag.,35:306-326.

CHAO, S. e TAYLCR, W.H. (1940) I somorphous replacement and superlattice structure in the plagioclase feldspar.Royal Soc.London Proc. Ser. A., 176: 76-87.

CHAYES, F. (1949) A simple point-counter for thin section analyses. Amer.Mineral., 134: 1-11.

CHRISTIE, O.H.J. (1959) Note on the equilibrium between plagioclase and epidote. Norsk Geol. Tidsskr., 39: 268-271.

CORDANI, U.G. e BITTENCOURT, I. (1967) Determinações de idade potässio-argônio em rochas do Grupo Açungui. An. XXI Congr.Bras.Geol., 218-233.

CORDANI, U.G. e GIRARDI, V.A.V. (1967) Geologia da Folha de Mor retes. Bol. Univ.Fed. Paranä. Geologia,26: 1-40.

CORDANI, U.G. e KAWASHITA, K. (1971) Estudo geocronológico,pelo mëtodo Rb-Sr, de rochas graníticas, intrusivas no Gru po Açungui. An.XXV Congr.Bras.Geol., 105-110.

CORDAN I, U.G. e ABRÃO, P.C. (1974) Comentärios sobre as determi nações geocronolögicas da Folha de Curitiba. In "Car ta Geológica do Brasil ao Milionésimo, Folha de Curitiba SG-22, texto explicativo", 61-65, M.M.E./D.N.P.M. - Brasilia. 
DEER, W.A. (1938) The composition and paragenesis of the hornblendes of the Glen Tilt Complex, Perthshire. Mineral. Mag., 25: 56-74.

DEER, W.A.; HOWIE, R.A. e ZUSSMAN, J. (1963) Rock forming minerals. Chain silicates. Vol. 11. Longmans, London.

DOMINGUES, A.J. (1945) Relatório geral da excursão ao Paranā e Santa Catarina, $103^{a}$ Tertülia do Cons.Nac.Geogr. Bol. Geogrä́ico, 25: 75-82 - Rio de Janeiro.

ENGEL, A.E.J. e ENGEL, C.G. (1962a) Progressive metamorphism of amphibolite, Northwest Adirondack Mountains, New York, Bull.Geol.Soc.Amer., Buddington Volume, 37-82.

ENGEL, A.E.J. e ENGEL, C.G. (1962b) Hornblendes formed during progressive metamorphism of amphibolites, Northwest Adirondack Mountains, New York. Bull. Geol. Soc. Amer., 73: 1499-1514.

ENGEL, A.E.J.; ENGEL, C.G. e HAVENS, R.G. (1961) Variations in properties of amphibolites, Northwest Adirondack Mountains, New York, U.S.Geol.Survey Prof. Paper,424C:313316.

ENGEL, A.E.J.; ENGEL, C.G. e HAVENS, R.G. (1964) Mineralogy of anphibolite interlayers in the gnaiss complex, Northwest Adirondack Mountains, New York.J.Geology,72:131-156

FUCK, R.A. (1966) Nota explicativa da Folha Geológica de QueroQuero. Bol. Univ.Fed.Paranä. Inst.Geol.,Geologia, 19.

GAY, P. e SMITH, J.V. (1955) Phase reaction in the plagioclase feldspar; composition range An 0 to An 70 . Acta Kryst., 8: 64-65.

GIRARDI, V.A.V. (1969) Petrologia das rochas metamörficas da região de Morretes-Antonina, Pr.Tese de doutotamento.Ins tituto Geociências e Astronomia, Universidade de São Paulo (inédito).

GIRARDI, V.A.V. (1971) Os anfibolitos da região de Morretes - An tonina, PR. Rev.Bras. Geoc., 1: 43-65.

GIRARDI, V.A.V. e SANTINI, P. (1973) The magnesian schists from the Morretes-Antonina area, Paranä. Rev.Bras. Geoc.,3: 181-191.

GOMES, C.B. (1962) Contribuição ao conhecimento dos anfibolitos da região de Jaraguã,SP. Soc.Bras.Geol.,11: 57-78. 
GOMES, C.B. (1971) Polimetamorfismo dos anfibolitos do Jaraguá, São Paulo: Evidências Químicas, Mineralögicas e Texturais. Tese de Livre-Docência. Instituto de Geociências, Universidade de São Paulo (inēdito).

GOMES, C.B. (1972) Chemical changes in plagioclases and their be aring on the petrologic history of an amphibolite body. Amer. Min., 57: 1860-1870.

GOMES, C.B. (1973) Nota sobre os minerais opacos dos anfibolitos do Jaraguà, SP. An.Acad.bras. Ciênc., 45: 103-107.

GOMES, C.B.; GASTUCHE, M.C.0. e DUTRA, C.V. (1972) Anfibölios do corpo anfibolítico do Jaraguä, SP. Rev.Bras.Geoc., 2 : 236-259.

GOMES, C.B.; SANTINI, P. e DUTRA, C.V. (1964) Petrochemistry of a precambrian amphibolite from the Jaraguá Área, São Paulo, Brazil. J.Geol., 72: 664-680.

HALLIMOND, A.F. (1943) on the graphical representation of the calciferous amphiboles. Amer. Mineral., 28: 65-89.

HARRY, W.T. (1950) Aluminum replacing silicon in some silicate lattices. Mineral. Mag., 29: 142-149.

HASUI, Y.; CARNEIRO, C. DaI R. e COIMBRA, A.M. (1975) The Ribeira Folded Belt. Rev.Bras.Geoc., 5: 257-266.

HOWIE, R.A. (1955) The geochemistry of the charnokite series of Madras, India. Trans.Roy Soc.Edinburgh, 62: 725-768 (ci taçäo em ENGEL et al., 1964).

HUSSAK, E. (1904) Uber die Mikrostruktur einiger brasilianischer Titanmagneteisensteine, Neues Jahrbuch fur Minera logie, Geologie und Paleontologie, p.94 (citação em LEONARDOS, 1938).

JUNG, J. e ROQUES, M. (1952) Introduction à l'ëtude zoneographique des formations cristallophylliennes. Bull. Serv. Geol. France, 50:61.

LAVES, F. (1954) The coexistence of two plagioclases in the oligoclase compositional range. J.Geol., 62: 409-411.

LEAKE, B.E. (1964) The chemical distinction between ortho and pa ra-amphibolites. J.Petrol., 5: 238-254. 
LEAKE, B.E. (1965) The relationship between composition of calci ferous amphibole and grade of metamorphism in controls of metamorphism. Pp. 299-318, Ed. W.S.Pitcher e G. M. Flinn. Oliver and Boyd, Edinburgh.

LEAKE, B.E. (1968) A Catalog of Analyzed Calciferous and Subcalciferous Amphiboles Together with their Nomenclature and Associated Minerals. Geol. Soc. Amer. Sp. Paper, $98: 1-210$.

LEINZ, V. (1938) Einsenerz-verkommen in Paranā, Brasilien-Zeitschrift für Min. etc. Jahrgang, Abt. A, n:2, s 42. (citação em CORDANI e GIRARDI, 1967).

LEONARDOS, O.H. (1938) Ferro no Paranä. Bol. D.N.P.M.- S.F.P.M., $25: 1-65$.

MAACK, R. (1947) Breves notícias sôbre a geologia dos Estados do Paranä e Santa Catarina. Arq.Biol. Tecn. IBPT,1:65-154. Curitiba.

MAACK, R. (1953) Mapa geológico do Estado do Paranä. Ed.Comissão de Comemorações do Centenārio do Paranā, Curitiba.

MAACK, R. (1961) Sôbre a ocorrência de granitos alcalinos no estado do Paranä e sua posição dentro das fases orogenéticas algonquianas. Bol.Univ.Paranä, Geologia, 4.

MARINI, 0.J.; TREIN, E. e FUCK, R.A. (1967) o Grupo Açungui no Estado do Paranä. In Geologia do pré-devoniano e intru sivas subseqüentes da porção oriental do Estado do Paranä. Bol. Paran.Geoc., 23 'a $25: 43$.

MIYASHIRO, A. (1968) Metamorphism of Mafic Rocks. In Basalts, Vol. 2 , pp. 799-834.

NOBLE, D.C. (1962) Plagioclase unmixing and the lower boundary of the amphibolite facies, J.Geol,, 70: 234-240.

OLIVEIRA, E.P. (1927) Geologia e recursos minerais do Estado do Paranä. Monografia VI, Serv.Geol.Min. Bras.,Rio de Janeiro.

PHILLIPS, F.C. (1930) Some mineralogical and chemical changes in duced by progressive metamorphism in the green bed group of the Scottish Dalradian. Mineral.Mag.,22: 239256 . 
RAMBERG, H. (1944) Petrological significance of some-solidus pha se transitions in mixed crystals. Norsk Geol. Tidsskr, 24, 1-2: 42-74.

RoXo, M.G.0. (1937) Minërios de ferro do Brasil. Terceiro Congresso Sul-Americano de Química.

RUELLAN, F. (1945) Interpretação geomorfolögica da Serra do Mar no Parana. $103^{a}$ Tertülia do Cons.Nac. de Geografia(27-3-1945), Bol. Geogräfico, 25: 81-82. Rio de Janeiro.

SHIDO, F. (1958) Plutonic and metamorphic rocks of the Nakoso and Iritono districts in the central Abukuma Plateau. Univ.Tokyo, J.Fac.Sci., Sec. 2, 11: 131-217.

SHIDO, F. E MIYASHIRO, A. (1959) Hornblendes of basic metamorphic rocks. Univ.Tokyo, J.Fac.Sci., Sec.2, 12: 85-102.

THOMPSON, J.B. (1947) Role of aluminum in the rock-forming sili cates. Bull. Geol.Soc.Amer., 58: 1232 .

TILLEY, C.E. (1924) Contact metamorphism in the Comrie Area. Quart. J.Geol. Soc.London, 80: 22-71.

TURNER, F.J. (1968) Metamorphic Petrology, Mineralogical and Field Aspects. McGraw-Hill Book Company, New York.

TURNER, F.J. e VERHOOGEN, J. (1960) I gneous and Metamorphic Petrology. McGraw-Hill Book Company, New York.

VOGT, Th. (1927) Sulitelmafeltets geologi og petrografi. Norges Geol. Unders, 121, 560 p. (citação em MIYASHIRo, 1968, p.817).

WAARD, D. de (1959) Anorthite content of plagioclase in basic and pelitic crystalline schists as related to metamorphic zoning in the Usu massif. Timor. Amer.J.Sci. 257: $553 \cdot 562$.

WALKER, K.R.; JOPLIN, G.A; LOVERING, J.F. e GREEN, R. (1960) Metamorphic and metassomatic convergence of basic igneous rock and lime-magnesia sediments of the precam brian of North-Western Queesnsland. J.Geol.Soc. Austra lia, 6: 149 . 
WENK, E.; SCHWANDER, H. e STERN, W. (1974) on calcic amphiboles and amphibolites from Lepontine Alps. Schweiz.Min.Petr. Mitt. Band 5:, Heft 1: 97-149.

WISEMAN, J.D.H. (1934) The central and south-west highland epidiorites: a study in progressive metamorphism.Quart.J. Geol. Soc. London, $30: 354-417$. 